\title{
ECOLOGIA DE CULICÍDEOS EM ÁREA PROTEGIDA INSERIDA NO ECOSSISTEMA URBANO, 1996-1998. GUARULHOS, SÃO PAULO.
}

\section{CARMEN B. TAIPE LAGOS DA COSTA}

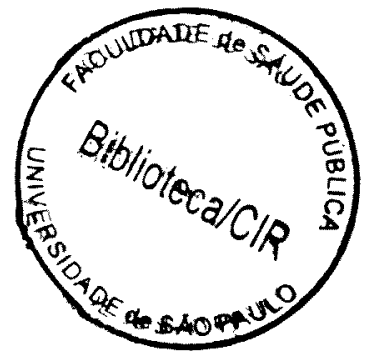

Tese de Doutorado apresentada ao Departamento de Epidemiologia da Faculdade de Saúde Pública da Universidade de São Paulo para obtenção do Grau de Doutor.

Área de concentração:

Epidemiologia

ORIENTADOR: PROF. DR.

DELSIO NATAL

Sāo Paulo 
Autorizo, exclusivamente para fins acadêmicos e científicos, a reprodução total ou parcial desta tese, por processos fotocopiadores.

Assinatura:

Data: 
AOS MEUS PAIS, a Raquelita, minha mãe,

exemplo de amor, força e coragem.

Ao Sérgio, Sérginho e Fabinho, que me motivam intensamente. 


\section{AGRADECIMENTOS}

Meus reconhecidos agradecimentos ao Prof. Dr. Delsio Natal, pela orientação prestada, amizade e estímulo constante.

Ao Conselho Nacional de Pesquisa (CNPq) pela bolsa de estudos concedida (processo 840220/96-0).

Á Fundação de Amparo à Pesquisa do Estado de São Paulo ( FAPESP ) (processo 95/09087-1) pelas facilidades concedidas.

À Direção e funcionários do Parque Ecológico do Tietê, pela colaboração na utilização das dependências do Parque.

Aos amigos e colegas Prof. José Maria Soares Barata, Paulo Urbinatti e Walter Ceretti pela paciência e presteza com que me auxiliaram nos trabalhos de campo e laboratório.

Ao Luís Pereira, Akemi Suzuki e Renato de Souza do Instituto Adolfo Lutz, pelo auxilio de transporte e apoio nos trabalhos de campo.

À Celuta Paganelli e Carlos Eduardo Cruz pelo estímulo constante, incentivo e revisão do resumo em Inglês.

À Profa. Maria Anice M. Sallum e ao Biólogo Aristides Fernandez pela identificação e confirmação dos espécimes de Culex subgênero Melanoconion.

Aos funcionários do Departamento de Epidemiologia. Á Leni Pires Das Merces pelos auxílios prestados na elaboração das figuras e orientações nos programas de computação.

Aos funcionários do Departamento de Prática da FSP/ USP que facilitaram o laboratório e equipamento para a realização do teste de precipitina.

Ao Edson Cabral da INFRAERO, pelos dados metereológicos fornecidos.

A todas as pessoas que direta ou indiretamente contribuiram com a realização desse trabalho. 


\section{SUMMARY}

Costa C.B. Ecology of Culicidae mosquitoes in protected area enclosed in an urban ecosystem, 1996-1998. Guarulhos, São Paulo, Brazil. 2000. [Doctorate thesis Faculdade de Saúde Pública - Universidade de São Paulo].

Objectives. Identification and estimation of the diversity, abundance, dominance and activity of Culicidae mosquitoes in diverse ecosystems and to discuss the epidemiologically important species. Methodology. Collect trips were performed monthly in: forested, open vegetation and urban habitat. Battery powered aspirators, $\mathrm{CDC}$ and Shannon traps were used for collecting through the day, at sunset and early evening period. Mosquitoes were also collected with light traps, human baits and electric aspirators in the peridomicile through 24 consecutive hours. Engorged specimens collected with CDC traps were tested with human antisera precipitin test. Results. Twenty five species or generic groups were identified out of 53,496 specimens collected. Aedes scapularis, Culex quinquefasciatus and Culex declarator were the most frequent species and were found in all the environments studied. Ae. scapularis was the most abundant, dominant and frequent. This species was prevalent in the open vegetation habitat, what suggests endofilic tendency. In the peridomicile, Ae. scapularis showed peaks of activity at nightfall, at early evening and in the morning. $C x$. quinquefasciatus was more active at night and early evening, thus confirming its endofilic nature. $C x$. declarator occured more frequently in the open vegetation habitat and was also active at nightfall in the peridomicile. Culicidae activity is related to pluviometric index and temperature although the correlation was low. Increased Culicidae activity also coincidental with climatic effects of "El Niño". $C x$. quinquefasciatus showed greater positivity to primate blood followed by $C x$. chidesteri and Ae. scapularis. Cx. quinquefasciatus, $C x$. chidesteri and $C x$. declarator were more sinanthropic species. Conclusions. Species of possible epidemiological importance are: Ae. albopictus, Ps. ferox, Cx. ribeirensis, Cx. nigripalpus, An. albitarsis. It is also remarkable the great abundance and frequency of Ae. scapularis, Cx. quinquefasciatus and $C x$. declarator. We present additional evidences that corroborates the adaptation of Ae. scapularis to altered environments. The need for Survillaince Arbovirus Program, further studies of its vector potential and control of the $C x$. quinquefasciatus are emphasized.

Keywords: ecology, Culicidae synanthropy, urbanization, development 


\section{SUMÁRIO}

I. INTRODUÇÃO 1

OBJETIVOS 11

2.1 Objetivo Geral 11

2.2 Objetivos Específicos 11

3. ÁREA DE ESTUDO 12

4. METODOLOGIA 17

$\begin{array}{ll}\text { 4.1. Coleta de mosquitos } & 17\end{array}$

4.2. Transporte e identificação de mosquitos $\quad 18$

4.3. Levantamento de dados meteorológicos 18

4.4. Processamento de dados $\quad 19$

4.4.1. Cálculo das Médias Horárias 19

4.4.2. Indice de Abundância 19

4.4.3. Índice de Diversidade 20

4.4.4. Índice de Dominância 20

4.4.5. Indice de Sinantropia 21

4.4.6. Quociente de Similaridade 21

4.4.7. Deteç̧ão de Sangue de Primatas 22

4.4.8. Freqüência domiciliar e atividade horária 22

4.4.9. Distribuição mensal das espécies mais abundantes 23

4.4.10. Cálculo do coeficiente de correlação 24

5. RESULTADOS E DISCUSSÃO 25

5.1. Freqüência espacial e temporal de culicideos 25

5.2. Abundância numérica e espacial de culicídeos 35

5.3. Diversidade e Dominância de culicídeos 38

5.4. Distribuição mensal das espécies mais abundantes 40

5.5. Freqüência de culicídeos no ambiente domiciliar 45

5.6. Atividade horária de culicídeos mais freqüentes no ambiente 46 domiciliar

5.7. Deteç̧ão de sangue de primatas $\quad 49$

5.8. Comportamento sinantrópico de culicídeos $\quad 52$ 
5.9. Potencial epidemiológico de algumas espécies registradas no local

6. CONCLUSÕES

7. REFERÊNCIAS

ANEXOS

Anexo 1. Ficha de campo para coleta de mosquitos adultos

Al

Anexo 2. Ficha de laboratório e codificação para mosquitos A2

Anexo 3. Lista do material entomológico depositado na coleção científica da FSP-USP.

Anexo 4. Programa de Gerenciamento do banco de dados em Dbase

Anexo 5. Programa de dados configurados em SPSS PC

Anexo 6. Apresentação tabular dos dados para o cálculo do coeficiente de

correlação de Pearson segundo atividade mensal de Ae. scapularis, pluviosidade e temperatura média mensal.

Anexo 7. Apresentação tabular dos dados para o cálculo do coeficiente de

correlação de Pearson segundo atividade mensal de $C x$. quinquefasciatus, pluviosidade e temperatura média mensal

Anexo 8. Apresentação tabular dos dados para o cálculo do coeficiente de correlação de Pearson segundo atividade mensal de $C x$. declarator, pluviosidade e temperatura média mensal. 


\section{INTRODLÇÃO}

As doenças transmitidas por vetores têm aumentado atualmente nas diversas regiōes do mundo, sendo as áreas tropicais as mais afetadas. A urbanização, o aumento populacional, empreendimentos de manejo da água, alterações ecológicas, redução de fontes de serviços de saúde, aumento da densidade e expansão geográfica dos vetores, carência de medidas efetivas de controle de vetores, dispersão geográfica de agentes e sua variação genética, despontam entre as causas desse panorama.

Existem inter-relações entre a urbanização e a domiciliação de insetos pois muitos desses se adaptaram e encontram-se hoje como pragas, ou tornando urbanas doenças transmitidas por vetores, atingindo a saúde publica, principalmente dos países em desenvolvimento. $\mathrm{O}$ crescimento de populações de culicideos e a epidemiologia de doenças transmitidas por esses mosquitos em regiões tropicais e temperadas colocam em destaque a Malária, a Filariose e as Arboviroses. Fatores como a drenagem de habitats naturais, desmatamento, uso da água, esgotos inadequados, dispersão passiva de espécies de mosquitos de importância médica, movimentos da população para centros urbanos, animais vertebrados associados com a urbanização entre outros, afetam a sobrevivência, proliferação e portanto a composição de espécies de mosquitos (FORATTINI e col., 1986 ; FRANKIE e EHLER, 1978 ; MITCHELL e col., 1994, KNUDSEN e SLOOFF, 1992 ).

Além de fatores antropogênicos, as Arboviroses apresentam uma distribuição associada a fatores ecológicos que governam seu ciclo de transmissão. Entre esses fatores destacam-se a temperatura, padrões de umidade e distribuição de vetores e hospedeiros vertebrados. Cerca da metade da população mundial vive em áreas de risco de arbovirose como a Dengue, com aproximadamente 10 milhões de casos registrados a cada ano. Na Asia, a Encefalite Japonesa tem expandido sua distribuição chegando à Austrália que já foi atingida por um foco epidêmico. No continente americano, epidemias de Encefalite Eqüina Venezuelana, Dengue, Febre Amarela, Oropouche entre outras, foram registradas nos Estados Unidos, Panamá, Venezuela, Colômbia, Peru, Equador e Brasil.(CHRISTENSEN e col., 1996; DAY e STARK 1996; FORATTINI e 
col., 1986 ; GUBLER 1996 ; LOPES e col., 1981; OBERSTE e col.,1998; VAIDYANATHAN e col., 1997; WATTS e col., 1998).

Segundo KARABATSOS em 1985, aproximadamente a metade dos arbovírus catalogados foram isolados de mosquitos. Alguns desses vírus estão relacionados com grande número de epidemias ocorrentes no mundo. No Brasil, as últimas décadas foram marcadas por epidemias como a Dengue, a Encefalite Eqüina e o Rocio.

A importância epidemiológica de certas espécies de Culex (Culex) reside basicamente no seu envolvimento na manutenção e transmissão de arbovirose, particularmente do virus SLE na América Latina. Culex nigripalpus tem sido encontrado infectado por vírus agentes de Encefalites nos Estados Unidos da América, Trinidad e Jamaica. No Brasil, Culex nigripalpus foi assinalado como vetor potencial da Encefalite ST.Louis no Vale do Ribeira, São Paulo ( FORATTINI e col., 1995 ). Por sua vez, VASCONCELOS e col., ( 1991 ) isolaram vírus SLE a partir de espécimes de Culex coronator e Culex declarator na região Amazônica brasileira e enfatizaram a importância epidemiológica desses culicídeos na arbovirose.

Existem registros de casos de Dirofilarioses comumente diagnosticados em cães, gatos e que potencialmente podem atingir ao homem. A Dirofilaria immitis é o agente dessa helmintiase. Mais de 200 casos da doença são registrados em humanos no mundo. A transmissão vetorial dessa enfermidade é atribuída a culicídeos dos gêneros Culex, Aedes, Anopheles, Mansonia, Psorophora e Coquillettidia (SAUERMAN e NAYAR 1983; RODRIGUES-SILVA e col., 1995)

LOURENÇO DE OLIVEIRA e DEANE (1995) registraram a infectividade de Aedes scapularis e Aedes taeniorhynchus com larvas de Dirofilaria immitis no Rio de Janeiro. MACEDO e col., (1998) demonstraram a competência vetorial de Aedes scapularis para essa parasitose. Por sua vez, LABARTHE e col., (1998) assinalaram a potencialidade vetorial de Aedes scapularis, Aedes taeniorhynchus, Culex quinquefasciatus, Culex declarator, Culex saltanensis e Wyeomyia bourroli e revelaram a infectividade de Aedes scapularis, Aedes taeniorhynchus e Culex quinquefasciatus com larvas desse nemátode. 
No Estado de São Paulo, ocorreu uma epidemia de Encefalite entre 1975 e 1976 nas localidades de Cananéia e do Vale do Ribeira. $O$ agente etiológico provocador do evento foi classificado como um novo flavivirus e denominado vírus Rocio. Dados epidemiológicos revelaram que a doença acometeu mais os homens em relação às mulheres e às crianças. Muitas cepas foram isoladas de pacientes e uma única cepa foi isolada de ave, Zonotrichia capenensis. Estudos entomológicos e de infectividade em culicideos capturados em Cananéia, revelaram a presença do vírus (77V-14624) em Psorophora ferox. Por esse motivo, esse culicideo foi incriminado na transmissão dessa arbovirose (LOPES e col., 1975, 1978a, 1981).

Estudos entomológicos conduzidos em área de foco epidêmico da Encefalite do Rocio no Vale do Ribeira, São Paulo, registraram a abundância e antropofilia de Aedes scapularis. Esse fato, sugeriu o envolvimento desse culicideo na transmissão dessa arbovirose. No entanto, pesquisadores da época não descartaram a possibilidade do envolvimento de Psorophora ferox nessa epidemia ( FORATTINI e col., 1978, 1981).

A capacidade vetorial de Ae scapularis tem sido sugerida por FORATTINI (1961). A competência vetorial desse culicídeo para transmitir o virus Rocio tem sido demostrada laboratorialmente. Esse fato sustenta a hipótese do envolvimento desse mosquito na transmissão da mencionãda arbovirose ( MITCHAEL e FORATTINI, 1984; MITCHAEL e col., 1986 )

Diversos pesquisadores estudaram padrões de alimentação e a capacidade vetorial em populações de Aedes albopictus, verificando-se que o mosquito alimenta-se de uma grande variedade de fontes sangüineas. Esses autores discutiram o comportamento oportunista desse mosquito, conferindo-lhe a potencialidade vetorial na transmissão de Encefalites Eqüina e outras Arboviroses silvestres nos Estados Unidos. Além disso, esse mosquito é considerado vetor da Dirofilariose nos Estados Unidos e Japão ( SAVAGE e col., 1993 ; WILLIS e NASCI 1994 ; MITCHAEL e col., 1994; APPERSON e col., 1989 ; KONISHI 1989a, 1989b).

Por sua vez, NATAL e col., (1997) registraram no Parque Ecológico, pela primeira vez, a presença de imaturos de Aedes albopictus em uma Bromeliaceae. Esse 
fato reveste-se de importância epidemiológica por constituir mais um criadouro potencial na infestação desse culicídeo, em áreas de domínio desses vegetais.

Vários arbovirus patógenos para o homem do gênero Alphavirus possuem as aves como reservatórios. Os mosquitos ornitofilicos como Culex e Aedes estariam levando a transmissão para humanos.

$\mathrm{O}$ virus Ilhéus (ILH) tem sido detectado na América latina, associados com mosquitos Psorophora, Aedes, Culex, Haemagogus, Trichoprosopon, Sabethes e Coquillettidia. Tem ampla distribuição no Brasil. Esse virus é agente etiológico de doença febril em humanos e foi isolado pela primeira vez em 1944, a partir de mosquitos do gênero Aedes e Psorophora. Estudos sorológicos concomitantes a esse trabalho, relativos à pesquisa de arbovirus em aves silvestres no Parque Ecológico, revelaram a presença de arbovirus Ilhéus (ILH) nessas aves (SUZUKI e col. 1997; PEREIRA e col., 1997)

Diante dos relatos explicitados nos parágrafos anteriores, fica evidente a importância de se compreender melhor a fauna Culicidiana em nosso meio, pelo fato dela estar envolvida na transmissão de uma série de agravos à saúde.

Dado o enfoque desse trabalho, serão feitas a seguir algumas considerações sobre aspectos adaptativos de vetores como respostas às atividades antrópicas.

NUORTEVA, em 1963, considerou moscas sinantrópicas aquelas que têm capacidade de utilizar as condições favoráveis criadas pelo homem. De acordo com este conceito, ele criou e utilizou o indice de sinantropia, para analisar as relações entre califorídeos e o homem, e as preferências desses insetos por áreas colonizadas. Este indice é aplicado quando se comparam dados quantitativos de uma determinada espécie em três áreas ecológicas distintas; usando o mesmo método de coleta.

POVOLNY in GREENBERG, 1971 considerou o ambiente humano como uma antropobiocenose e as espécies animais que aí vivem, excetuado-se o próprio homem e os animais domésticos, são constituidas daquelas capazes de se adaptarem à novas condições surgidas, devido à sua grande valência ecológica. Sendo assim, a 
antropobiocenose contém três componentes: o homem; os animais domésticos introduzidos e mantidos pelo homem, e os animais sinantrópicos como membros espontâneos, mas indesejáveis para o homem. $\mathrm{O}$ mesmo autor considerou ainda outros tipos de biocenoses; a eubiocenose que representa o ambiente original e a agrobiocenose intermediária a essas. Esse ambiente transitório das áreas rurais, assinalou o autor, como sendo fundamental para o aparecimento e desenvolvimento da sinantropia.

FRANKIE e EHLER, em 1978, numa ampla revisão, enfatizaram a importância de estudos ecológicos de insetos em ambientes urbanos, para determinar o impacto da atividade humana em termos de extinção local de muitas espécies de insetos e a seleção para populações adaptadas a esses ambientes criados pelo homem.

Por outro lado, KOSTROWICKI, em 1982, definiu a sinantropização como um processo de adaptação de vários sistemas ecológicos a situações criadas pela atividade social do homem. Historicamente, comenta o autor que, junto com o desenvolvimento das forças produtivas e a divisão social do trabalho, a complexidade de formas de interferência ao ambiente foram crescendo gradualmente; a partir de um período prétecnológico, através de fases subseqüentes de tecnologias mecânicas e químicas empregadas. Para ele, a magnitude do desenvolvimento da tecnologia e a área atingida pela mesma são os elementos que interferem no ambiente.

Por sua vez GOMES, em 1986, assinalara que o processo de domiciliação envolve etapas distintas de evolução, sendo o caracter associativo com o homem inicialmente acidental podendo tornar-se facultativo ou até mesmo obrigatório.

Para FORATTINI (1992, 1996), o fenômeno de domiciliação ou sinantropia é uma condição representada pela adaptação de espécies ao convivio humano resultando na ocupação de nichos artificialmente criados no ambiente antrópico.

A adaptação ao ambiente antrópico de muitas espécies entre elas: Anopheles albitarsis, Aedes scapularis, espécies do gênero Culex tem sido verificada e, o papel epidemiológico dessas espécies já foi discutido sob alguns aspectos (FORATTINI e col., 1986, 1989, 1993; NATAL 1986; NATAL e col., 1991). 
A freqüência elevada de Aedes scapularis coletada em isca humana e em ambientes degradados tem confirmado a antropofilia e a possível adaptação desse culicideo nesses ambientes, salientando-se também seu possivel papel na transmissão da Encefalite e outras arboviroses (FORATTINI e col., 1978 a, 1987a, 1981; LOURENÇO DE OLIVEIRA 1984; MARQUES 1994; NATAL 1986).

A constatação científica da relação entre a ocorrência de determinadas doenças e a presença de culicídeos vem sendo confirmada há tempo. A hematofagia e a preferência por hospedeiros específicos são aspectos que motivam até hoje estudos relativos à capacidade vetorial desses mosquitos. Em particular, a antropofilia é uma variável de importância epidemiológica (REISEN 1989).

DEFOLIART e col, em 1987, ressaltaram que o contato entre mosquitos e vertebrados está sujeito à influência de fatores múltiplos como: a preferência alimentar, as tentativas de sugar, a realimentação, a reação comportamental do hospedeiro, além de outros. Por sua vez, CHRISTENSEN e col., em 1996, comentaram que os padrões de alimentação de culicídeos podem variar entre regiões, dependendo principalmente da disponibilidade do hospedeiro.

Estudos de preferência alimentar realizados por GUIMARÃES e col., em 1987, assinalaram a elevada antropofilia de Aedes scapularis quando coletados utilizando-se de gambá, lagarto e isca humana. Esses autores observaram também a nitida tendência de Culex nigripalpus à ornitofilia, principalmente em aves que adormecem nos estratos mais altos das árvores. No entanto, comentam os autores que a maioria desses mosquitos comportam-se como oportunistas, assinalando que o homem colocado como isca oferece maiores vantagens ao processo hematofágico.

Estudos relativos à preferência alimentar e domiciliação de mosquitos culicídeos no Vale do Ribeira, São Paulo, utilizando-se da técnica de precipitina e coletas com diversas técnicas inclusive a isca humana, mostraram o ecletismo alimentar do Aedes scapularis confirmando-se sua preferência por sangue de mamíferos de grande porte e o próprio homem. Os autores, assinalam que a potencialidade endofilica desse mosquito poderá levar ao desenvolvimento de hábitos domiciliados. Quanto ao $\mathbf{C}$. $(\mathbf{M e l}$.) ribeirensis, esse culicideo foi coletado predominantemente com isca humana $\mathrm{e}$ foi 
assinalada sua sobrevivência e desenvolvimento no ambiente antropicamente alterado (FORATTINI e col., 1986, 1987, 1989, 1991).

LOURENÇO DE OLIVEIRA e SILVA em 1985, quando pesquisaram a preferência horária de culicídeos para o hematofagismo em área de planície litorânea no Rio de Janeiro, assinalaram o comportamento eclético de Aedes scapularis, Aedes taeniorhynchus e Mansonia titillans. Quanto ao Aedes scapularis, registraram que sua densidade aumenta no final da tarde, tendo um pico de maior freqüência no crepúsculo vespertino, sua atividade durante a noite diminui gradativamente, capturando-se-o, porém, durante toda a noite.

Por sua vez, TEODORO e col., em 1994, confirmaram a possivel adaptação de Ae. scapularis em ambientes antropogênicos no Estado do Paraná, onde tem demostrado acentuada antropofilia. Esses autores registraram também, que a atividade hematofágica desse culicídeo apresentou picos das 18 às $19 \mathrm{~h}$, das 19 às $20 \mathrm{~h}$ e das 6 às $7 \mathrm{~h}$.

Por sua vez, LOPES e LOZOVEI em 1995, quando pesquisaram a fauna de culicídeos ao longo do leito de ribeirão com mata ciliar reduzida no Estado do Paraná, coletaram uma gama de espécies representantes dos gêneros Culex, Anopheles, Aedes, Aedeomyia, Psorophora e Uranotaenia. Esses autores concluíram que águas superficiais com floresta reduzida podem ser um refugio para algumas espécies de culicídeos, podendo contribuir com o processo de domiciliação das espécies.

FORATTINI, em 1965, assinalou que as formas adultas de culicídeos procuram abrigar-se em locais próximos ao seus criadouros ou às fontes de alimentação. Esta característica, quanto mais relacionada com o ambiente alterado, traduz capacidade da espécie à domiciliação, porém não assegurando-lhe a obrigatoriedade de estreito relacionamento alimentar com a população humana.

Estudos de comportamento alimentar, documentaram o ecletismo alimentar de Cx. quinquefasciatus por sangue de mamíferos e aves. Esse mosquito alimenta-se de sangue de humanos, cães e raramente por sangue de gatos. Quanto ao Aedes scapularis, também demostrou alimentação em humanos, caninos e felinos (FORATTINI e col., 
1987, 1987a, 1993, 1995; LABARTHE e col., 1998; LOURENÇO DE OLIVEIRA \& HEYDEN 1986).

Estudos relativos à composição faunistica de culicídeos em ambientes peridomiciliares e em abrigos no Estado do Paraná, realizados utilizando-se de isca humana e armadilha de Falcão, registraram a presença de Aedes scapularis, Anopheles albitarsis, Coquillettidia venezuelensis, Coquillettidia lynchi, Mansonia titillans e Aedomyia squamipennis. Esses autores, assinalaram que as mencionadas espécies mostraram-se com hábitos predominantemente antropofilico exceto Aedomyia squamipennis, que compareceu em abrigos de animais domésticos (TEODORO e col., 1994).

Estudos ecológicos realizados em áreas de irrigação de arrozais, evidenciaram a adaptação de Anopheles albitarsis e Aedes scapularis para o ambiente antrópico. Os autores atribuiram um alto grau de sinantropia para essas espécies correspondentes a $\mathrm{S}=$ $+99,9$ e $+71,0$ respetivamente (FORATTINI e col., 1993).

Estudos de dispersão e freqüência de culicídeos ao ambiente humano revelaram a acentuada capacidade de dispersão de Aedes scapularis, Culex sachettae, Aedes serratus, Culex nigripalpus e Culex ribeirensis, bem como da permanência no ambiente domiciliar. FORATTINI e col., 1990, 1993 assinalaram a assinantropia de Anopheles cruzii e comentaram que no mecanismo de domiciliação desses mosquitos, a presença de fontes sangüineas representada por animais domésticos, constituim-se em fator de atração para a população de mosquitos silvestres.

Por sua vez, MARQUES em 1994, quando investigara o comportamento antropofilico de culicídeos do Vale do Paraíba no Estado de São Paulo, registrara o comportamento antropofilico de Aedes scapularis, bem como de sua adaptação ao ambiente modificado.

Como consequêencia da urbanização e industrialização um vasto número de recipientes artificiais que podem acumular água fazem parte dos resíduos sólidos. Esses recipientes quando não são reciclados e/ou manejados adequadamente, além de poluírem o ambiente, servem de criadouros para culicídeos. No Estado do Paraná, 
registraram-se os mais variados tipos de recipientes albergando representantes predominantemente de Aedes aegypti, Culex quinquefasciatus, Culex coronator, Aedes fluviatilis e Limatus durhamii (LOPES e col., 1997).

Por sua vez, SILVA e MENEZES, em 1996 e FORATTINI e col., em 1997, notificaram a presença de formas imaturas de Aedes scapularis em criadouros artificiais como: lata abandonada, garrafas, pneu, caixas de água de cimento nos Estados do Paraná e São Paulo, respectivamente. Esse fato vem evidenciando a tendência sinantrópica desse Culicídeo favorecida por atividade antrópica.

GOMES e FORATTINI, em 1990, pesquisaram abrigos naturais de mosquitos Culex em zona rural e observaram que as atividades antrópicas têm afetado o comportamento desses mosquitos. Os autores salientaram que o conjunto Culex bidens, Culex dolosus e Culex chidesteri, mostrou-se de hábito tendente à urbanização

FORATTINI e col., em 1995, quando estudaram o comportamento de Aedes scapularis e Aedes serratus em relação às atividades de alimentação e ocorrência em diversos habitats antropicamente modificados no Vale do Ribeira do Estado de São Paulo. Esses autores observaram a tendência de Aedes scapularis para freqüentar o ambiente modificado, enquanto que Aedes serratus, mostrou tendência para áreas de floresta vestigial. Assinalaram também, a tendência endofilica de Aedes scapularis, sugerindo o desenvolvimento sinantrópico desse mosquito

Estudos ecológicos da fauna de culicídeos em áreas preservadas localizadas próximas aos aglomerados urbanos, tornam-se importantes porque permitem a compreensão das biocenoses envolvendo a população humana

SOUBIHE em 1994 documentou a presença de importantes espécies de culicídeos com potencial de transmissão de arbovírus no Parque Ecológico do Tietê Além disso, o Parque é ponto onde são destinados animais apreendidos procedentes de diversas regiões do pais, podendo permitir a introdução de virus silvestres no local. Por outro lado, existe pouca informação disponível em relação à sinantropia de culicídeos em áreas urbanas. Dessa maneira, justificou-se o estudo de aspectos ecológicos da fauna 
Culicideana, na tentativa de discutir aspectos adaptativos desses mosquitos e suas implicâncias epidemiológicas. 


\section{OBJETIVOS}

\subsection{Objetivo Geral}

Estudar aspectos ecológicos de culicídeos em área protegida inserida no ecossistema urbano.

\subsection{Objetivos Especificos}

1. Identificar as espécies de culicideos presentes na área.

2. Estimar a abundância de espécies em diferentes ambientes.

3. Avaliar a diversidade de espécies de culicídeos na área.

4. Calcular a dominância de espécies de culicídeos na área

5. Estimar a atividade horária de culicídeos em ambiente domiciliar.

6. Descrever a distribuição mensal e espacial das espécies mais abundantes, segundo técnica de coleta.

7. Estimar e discutir o comportamento sinantrópico e antropofilico dos culicideos mais freqüentes na área.

8. Discutir o potencial epidemiológico das espécies mais abundantes. 


\section{3. ÁREA DE ESTUDO}

O trabalho foi conduzido no Parque Ecológico do Tietê, cuja administração é de responsabilidade do Departamento de Águas e Energia Elétrica do Estado de São Paulo.

O local de pesquisa está na sub-área do parque representada pelo Parque Engenheiro Goulart. Localizado a $14 \mathrm{Km}$ do centro da cidade de São Paulo, possui 14000 ha, situando-se na zona leste da capital ( $23^{\circ} 25^{\prime} \mathrm{S}$ e $46^{\circ} 28^{\prime} \mathrm{W}$ ). É cortado pela Rodovia Ayrton Senna, incluída no município de Guarulhos ocupando áreas da planície de inundação do rio Tietê (Fig.1)

Quanto ao aspecto paisagístico, possui matas residuais, predominando espécies de eucaliptos, áreas abertas, um complexo de lagos de águas límpidas e poluídas, formadas pela retirada de areia das margens do Tietê, para a construção civil (Fig.2-19)

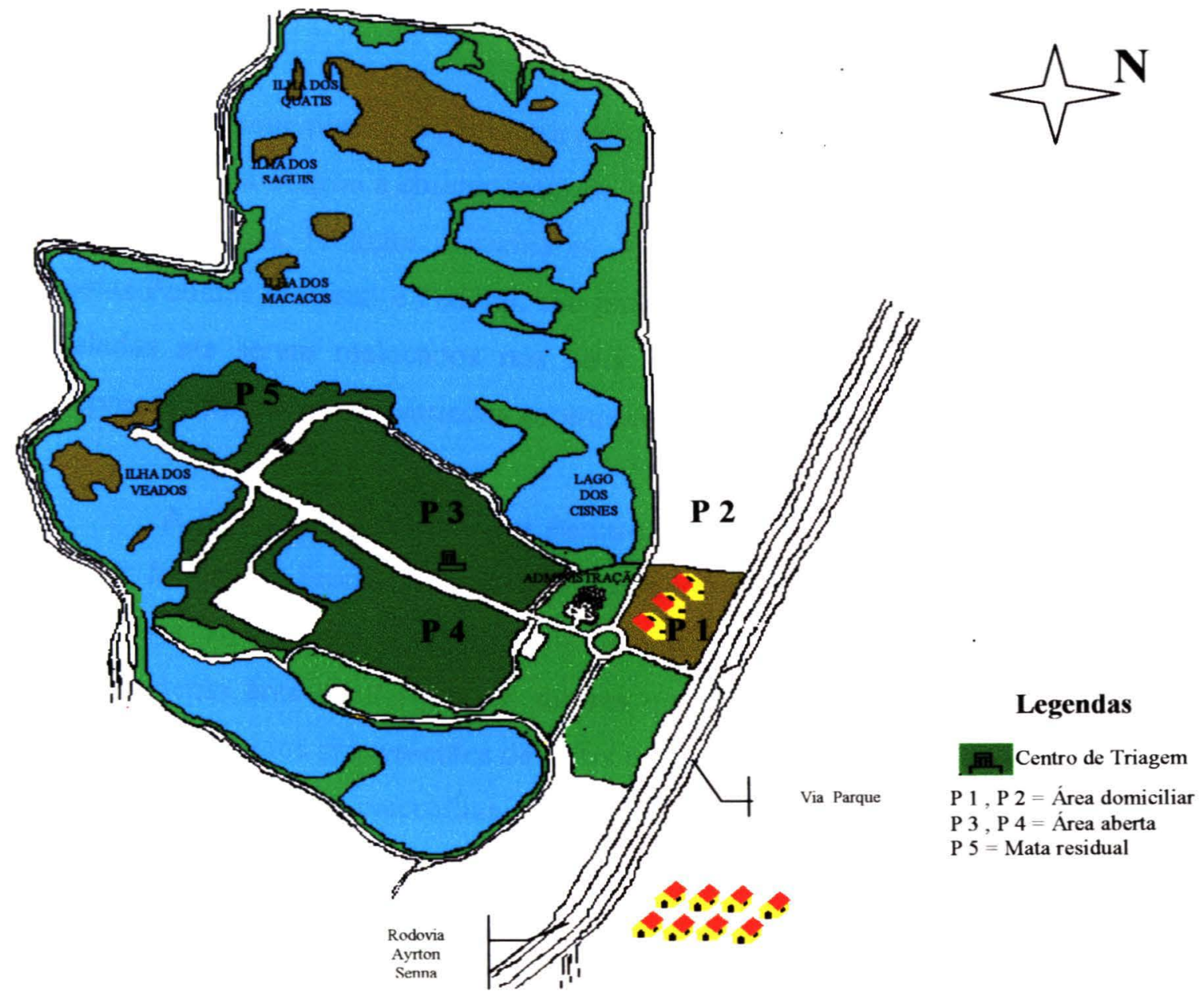

Figura 1. Representação esquemática da área de estudo no Parque Ecológico do Tietê, Guarulhos, São Paulo. 
A qualidade sanitária e ecológica das águas dos lagos, foram caracterizadas como possuindo alto grau de poluição e eutrofização (ROCHA, 1990).

Aproximadamente, 15 famílias residem oficialmente no interior do Parque e cerca de 4000 invasores. Quanto ao setor de recursos humanos, 60 funcionários trabalham efetivamente nos mais diversos serviços. No entanto, empreiteiras contratadas para segurança e limpeza representam aproximadamente 100 pessoas. A parte do Parque, que é destinada ao lazer, recebe em média cerca de 40000 visitantes por mês.

Segundo informação da direção do Parque, por ser um "enclave verde" situado em area de intensa urbanização, o Parque serve de parada para aves migratórias. Além disso, há uma fauna de mamiferos que há muito tempo foi introduzida no local. Essa fauna esta composta essencialmente por macacos e quatis

O Parque possui também um centro de triagem e recepção de animais silvestres. Esse centro já chegou a abrigar mais de 3000 animais. Os trabalhos são supervisionados por veterinários, biólogos e auxiliares. Tratam-se de animais que, quando apreendidos pelas Polícias Florestal e Federal, são para lá conduzidos onde permanecem em gaiolas teladas até serem realocados nos seus habitats naturais. O Parque recebe animais representantes dos mais variados ecossistemas do país (DAEE, 1989).

A área plana que ocupa o Parque, pertencente à planicie de inundação do rio Tietê, favorece a formação de inúmeros criadouros temporários de culicideos nas épocas de chuva. Além disso, a presença de uma série de lagos e do Rio Tietê que contorna uma extensa área do Parque são fatores que favorecem a proliferação de mosquitos. Córregos poluidos provenientes de áreas urbanas circunvizinhas também contribuem. A intensa expansão de macrófitas flutuantes Eicchornea sp. contribui na formação de habitat favorável aos mosquitos. Todo o Parque, enfim, pode ser considerado como área de elevada densidade de culicideos (SOUBIHE, 1995) 


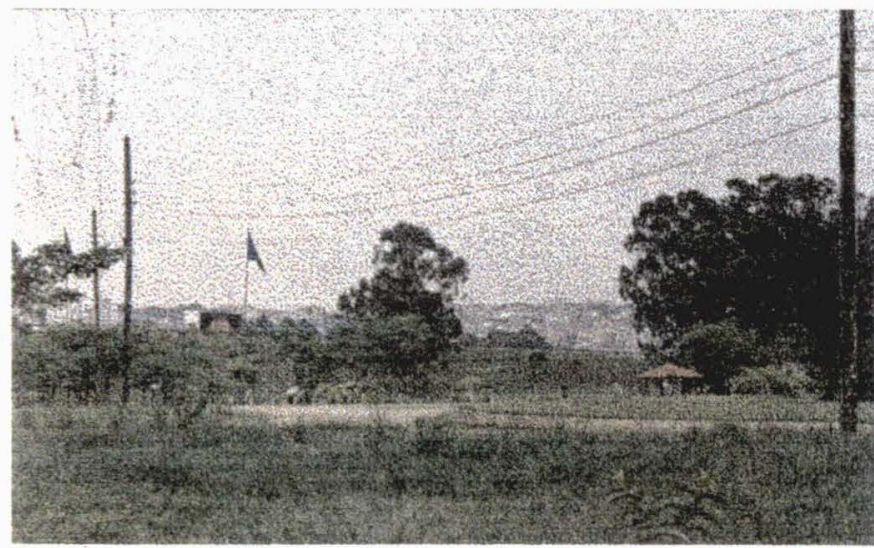

Figura 2. Parque Ecológico do Tietê inserido em ecossistema urbano.

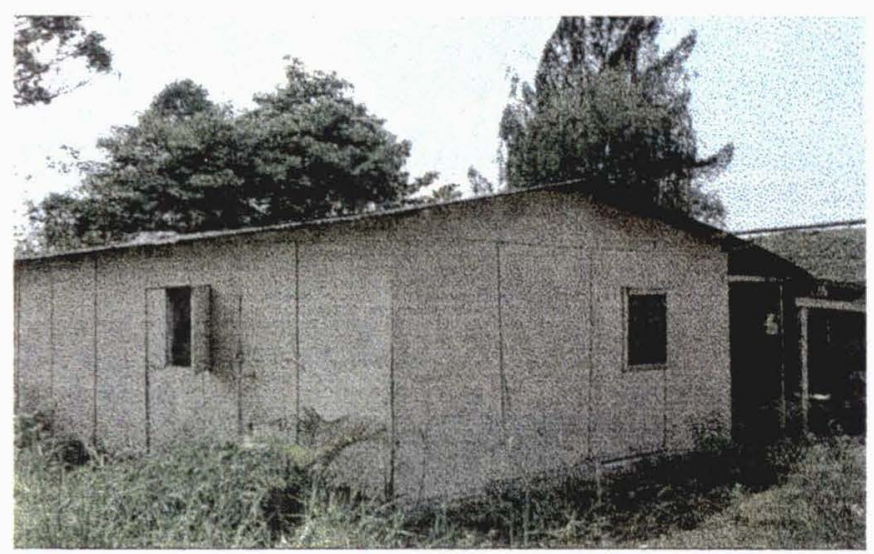

Figura 4. Domicílio usado para coleta nas proximidades da rodovia Ayrton Senna (P1).

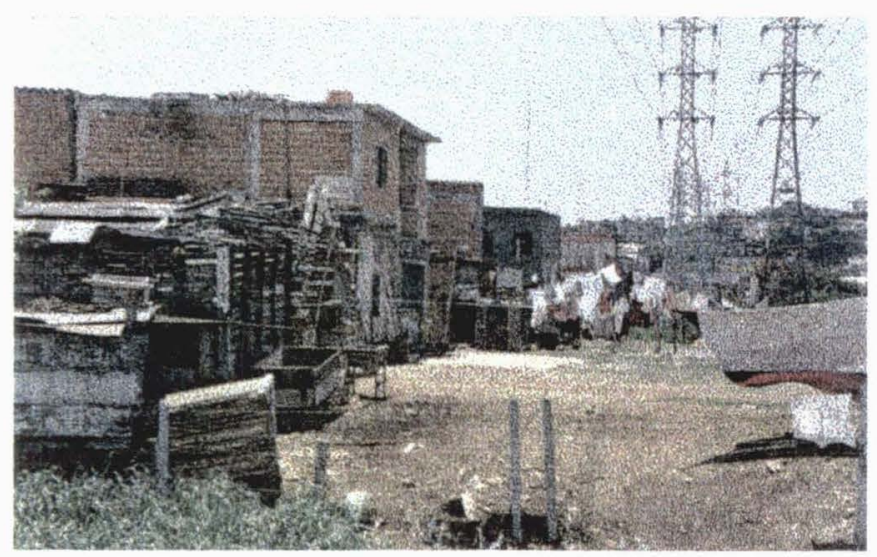

Figura 6. Área urbana de periferia próximo ao Parque Ecológico do Tietê.

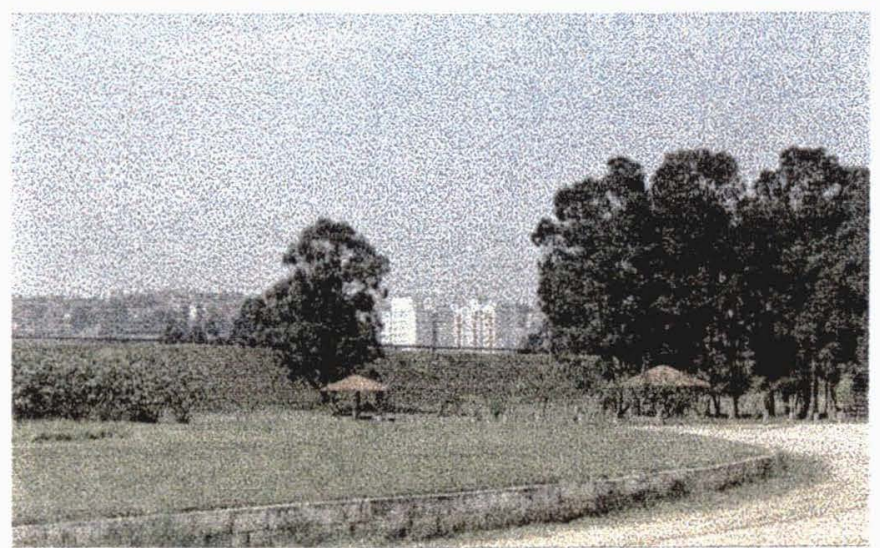

Figura 3. Vista da área de lazer do Parque Ecológico do Tietê. Ao fundo nota-se o ambiente urbano.

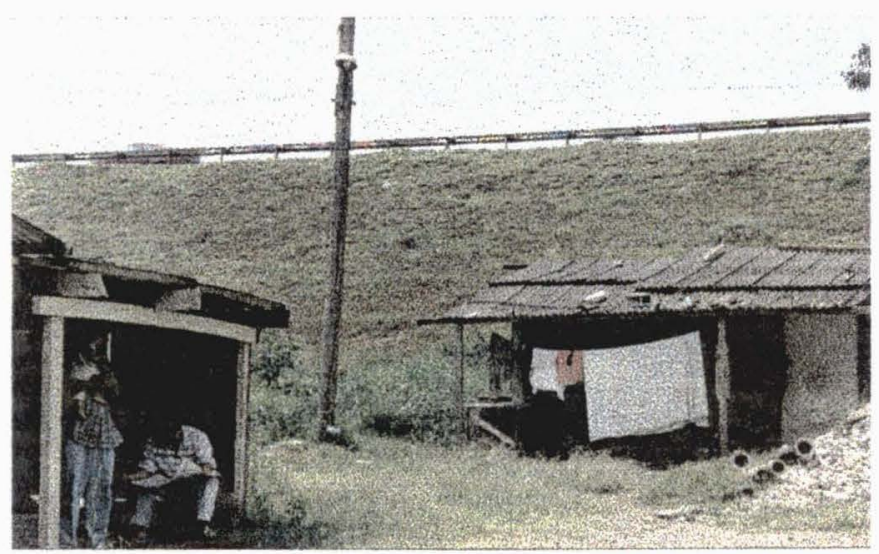

Figura 5. Peridomicílio mostrando ao fundo a rodovia Ayrton Senna (P2).

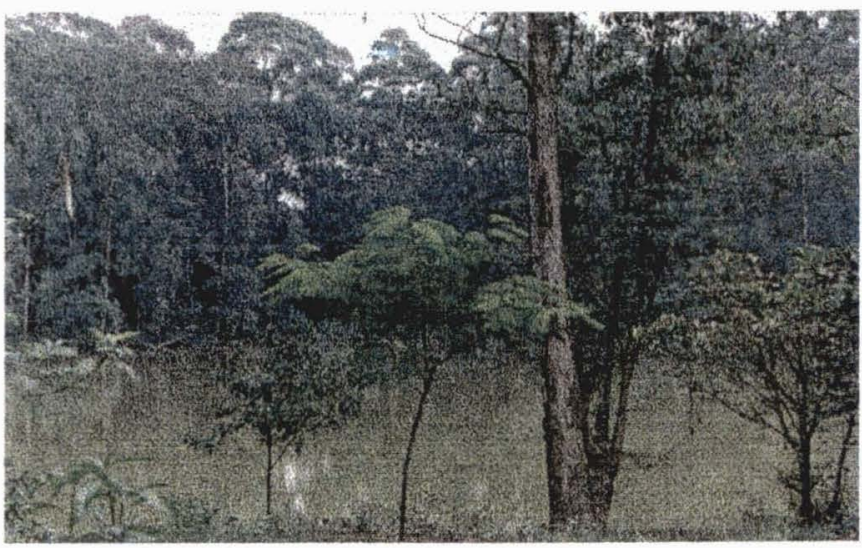

Figura 7. Lago circundado por bosque de eucalipto (P5). 


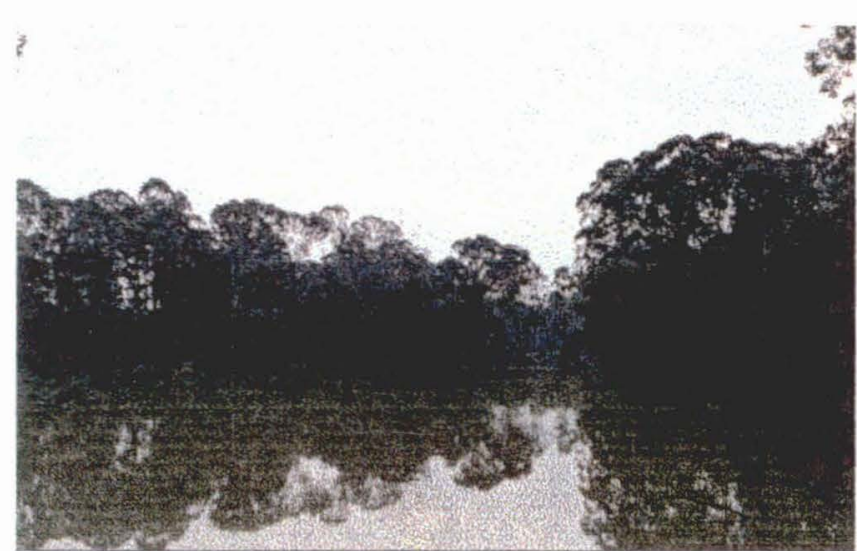

Figura 8. Lago circundado por bosque de eucalipto (P3).

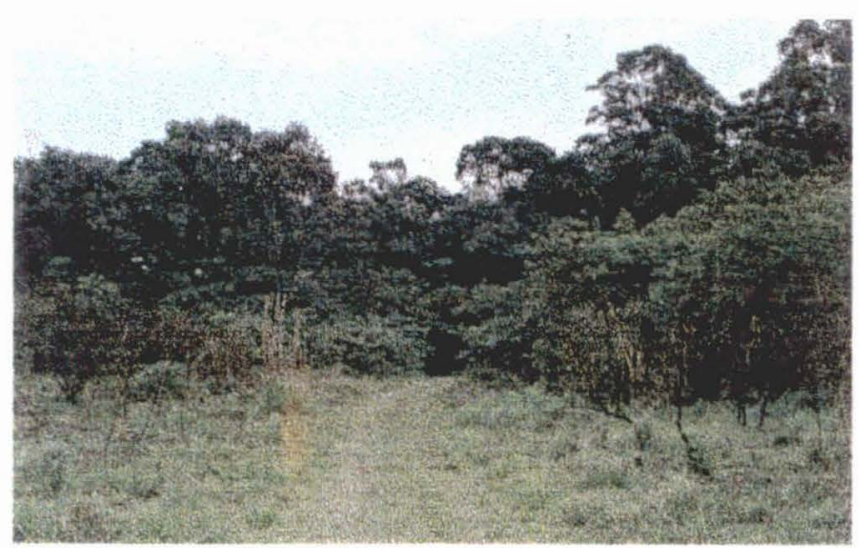

Figura 10. Vegetação aberta e mata no interior do Parque (P4)

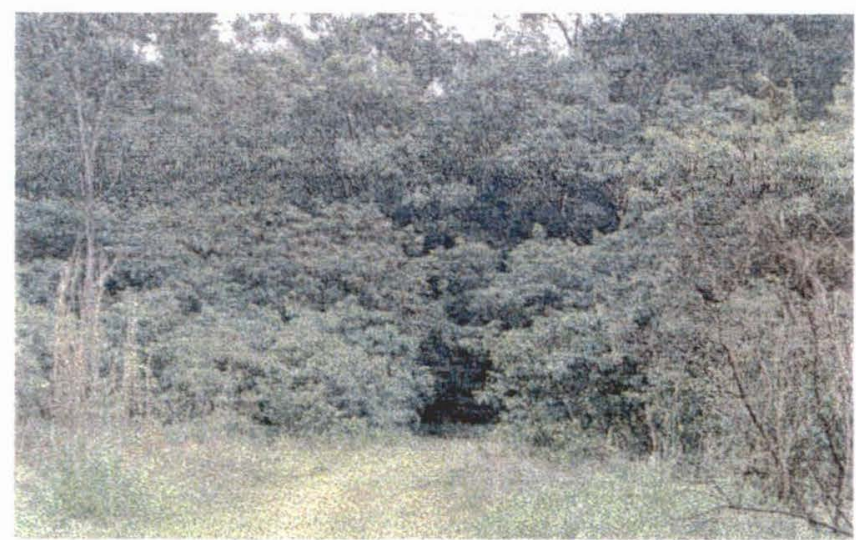

Figura 12. Mata de Eucalipto e Vegetação rasteira (P5).

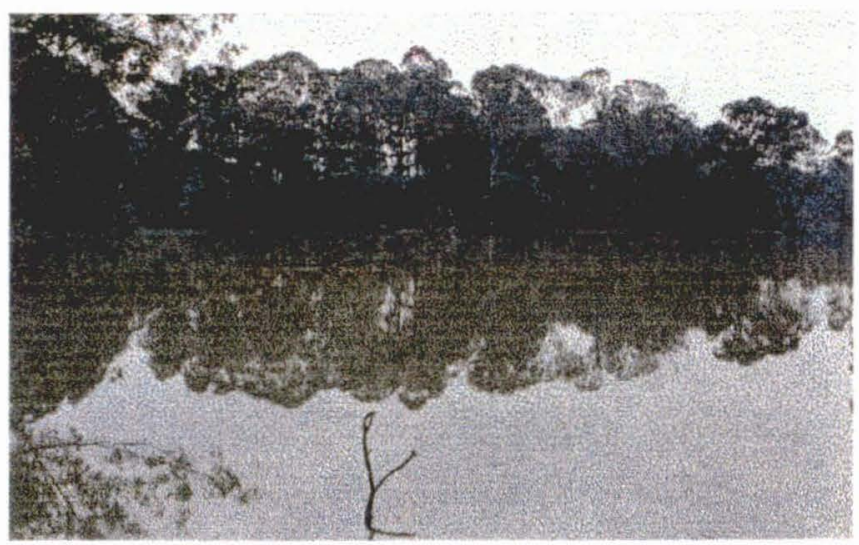

Figura 9. Extensos lagos poluídos no Parque Ecológico do Tietê (P3)

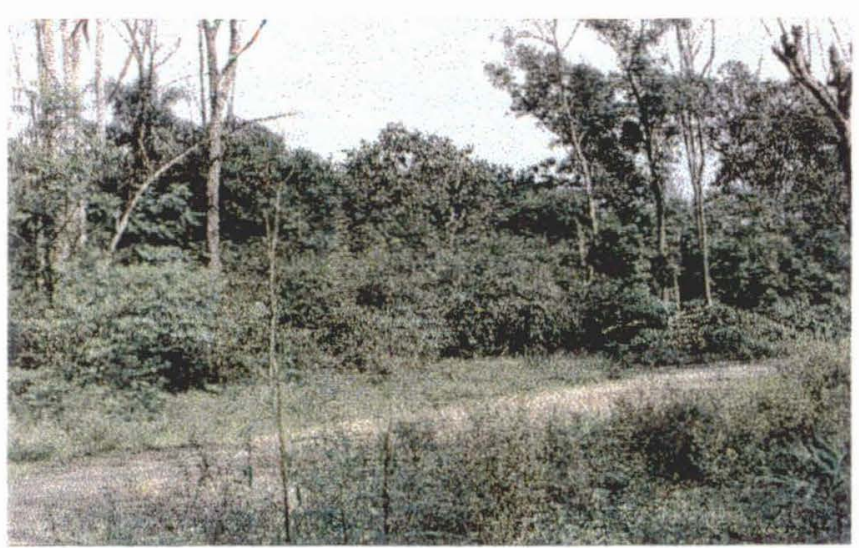

Figura 11. Linha de acesso no interior do Parque (P3).

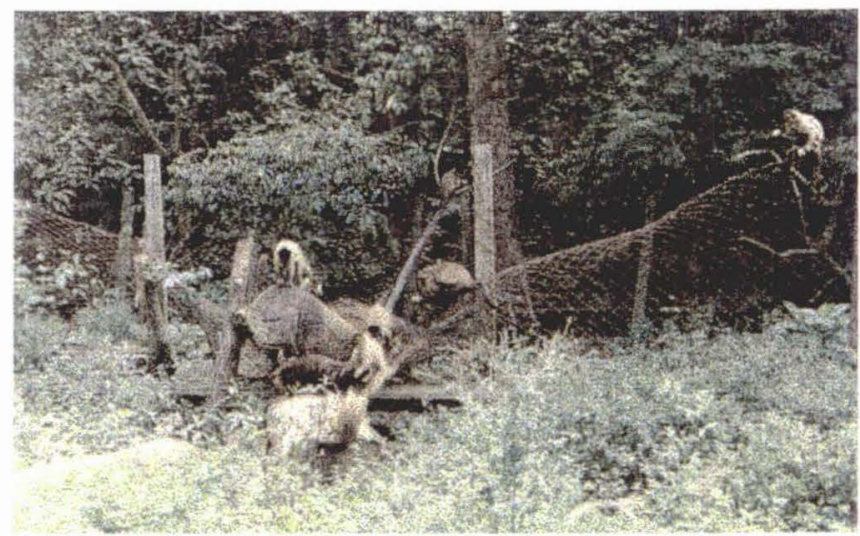

Figura 13. Presença de primatas no interior do Parque (P3). 


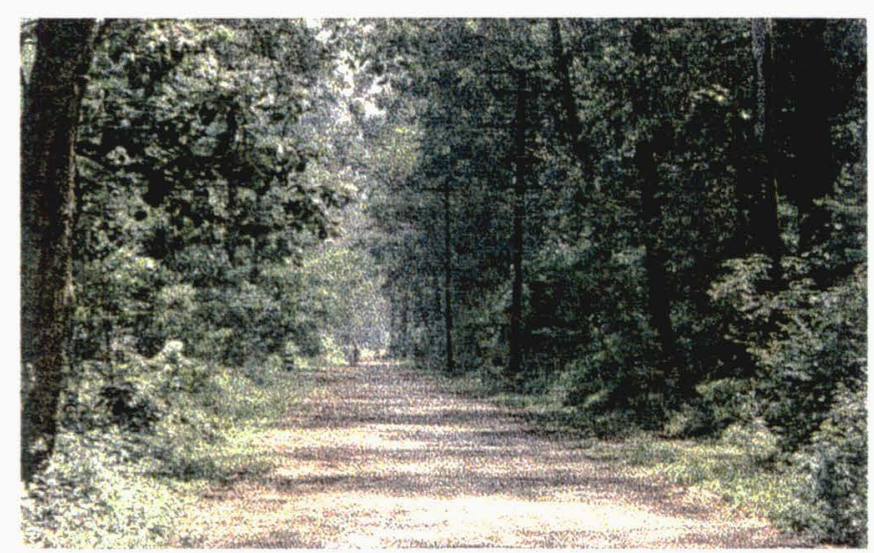

Figura 14. Caminho de acesso no interior do Parque (P5).

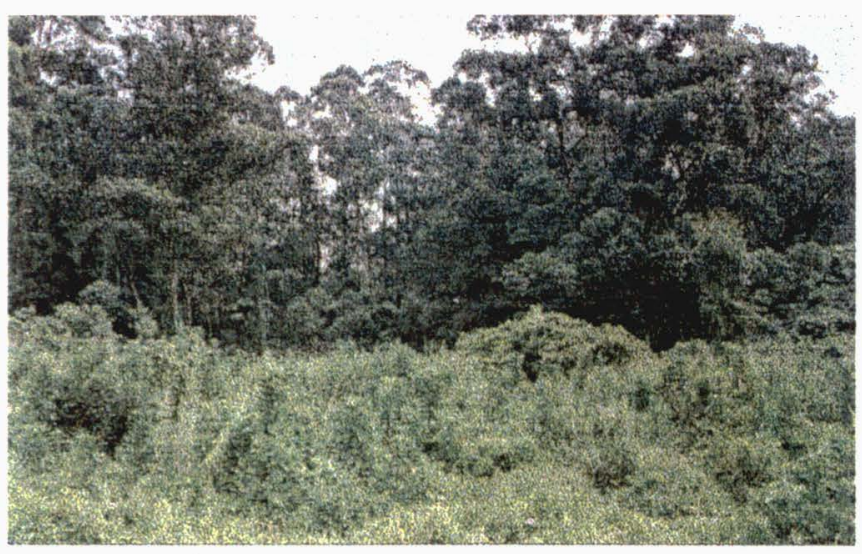

Figura 16. Área aberta e mata de eucalipto ao fundo (P4, P5)

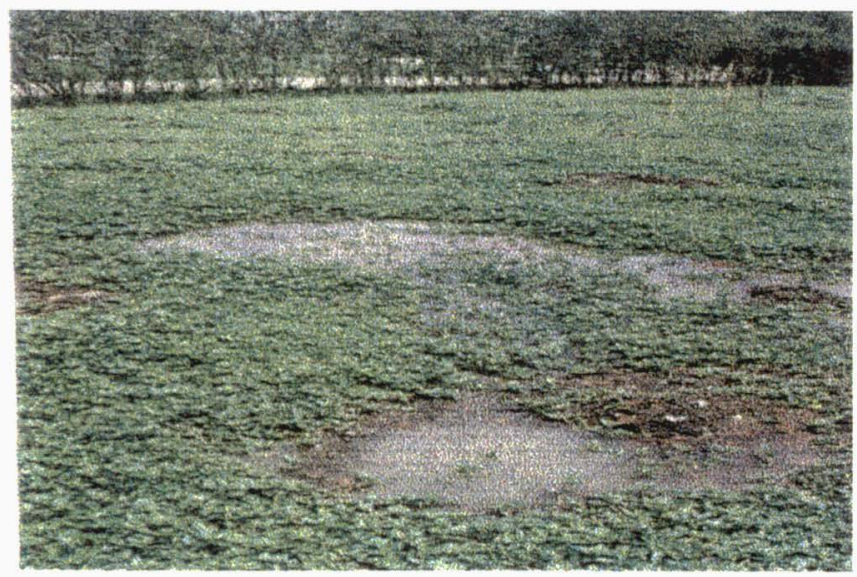

Figura 18. Criadouro de Ae. scapularis em ambiente aberto (P3).

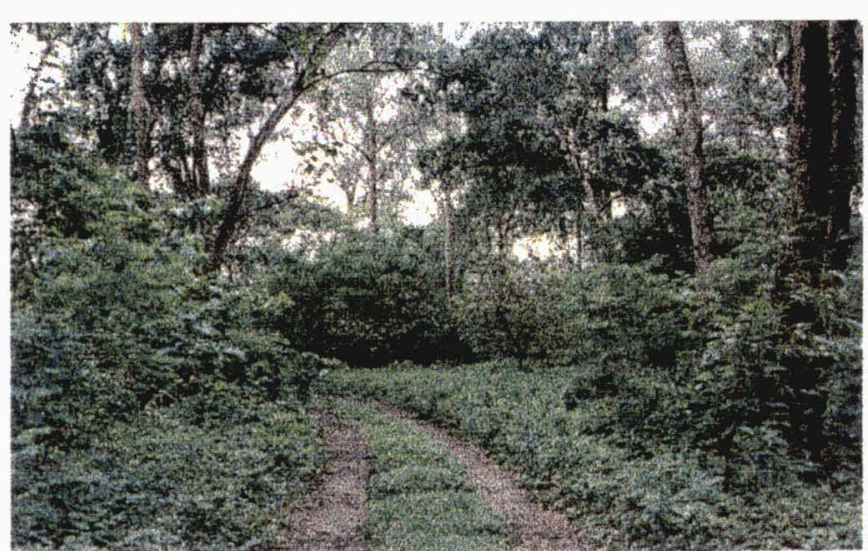

Figura 15. Caminho de acesso no interior da mata (P5).

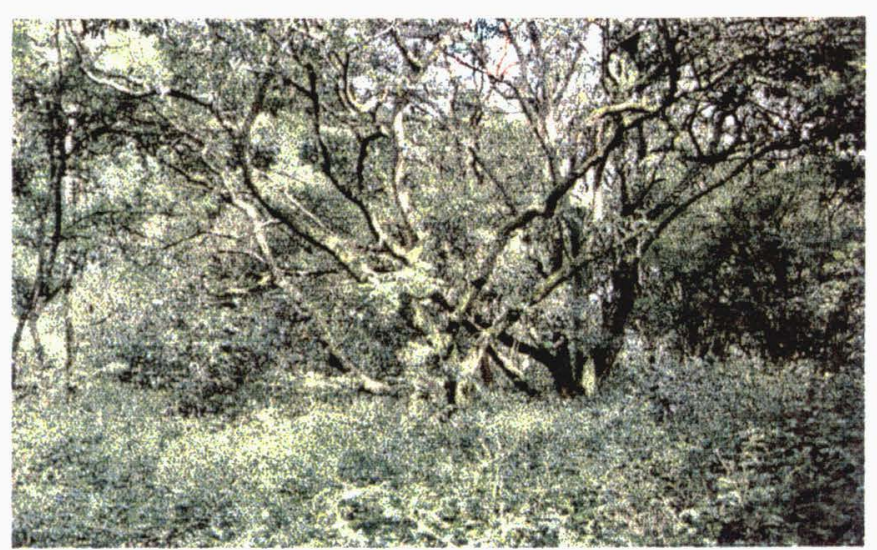

Figura 17. Interior da mata (P5).

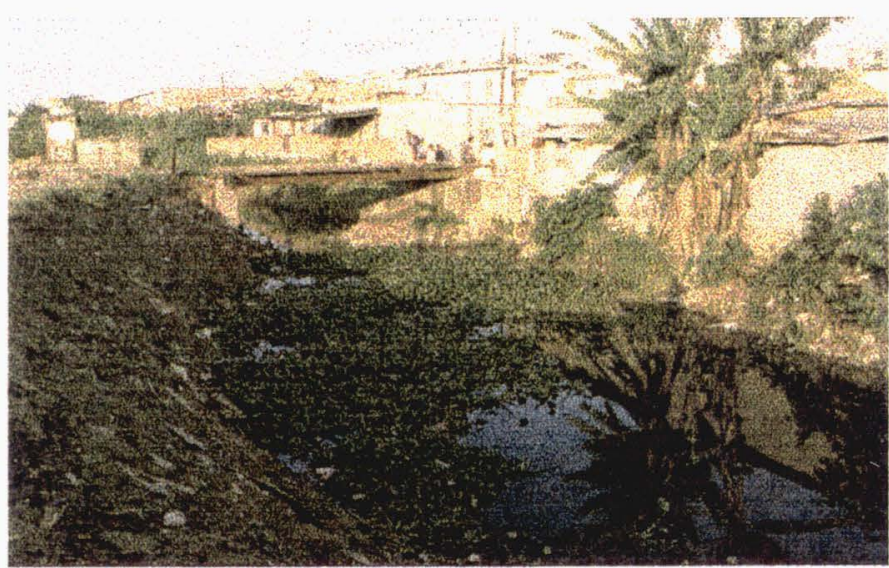

Figura 19. Córrego "Rio Negrinho" próximo ao Parque, criadouro de $C x$. quinquefasciatus. 


\section{METODOLOGIA}

4.1 Coleta de mosquitos adultos:

As coletas abrangeram três pontos com feições paisagisticas diferentes: a mata residual, a área de vegetação aberta e a área domiciliar. A periodicidade das capturas foi mensal, durante vinte meses. Cobrindo-se o perfil da paisagem as capturas foram realizadas utilizando-se de aspiradores a bateria (NASCI 1981) e armadilhas luminosas tipo CDC (SUDIA e CHAMBERLAIN 1962), suplementadas com atrativo (gelo seco) $\mathrm{Na}$ área aberta uma única armadilha de Shannon (SHANNON, 1939) foi operada

O Quadro 1. resume, as horas de captura gastas nos diversos habitats pesquisados, segundo as diversas técnicas.

Quadro 1. Demonstrativo de horas de captura gastas nos diversos habitats pesquisados utilizando-se das três técnicas no Parque Ecológico do Tietê. Guarulhos. São Paulo. 1996 a 1998.

\begin{tabular}{|c|c|c|c|c|c|}
\hline Técnica & Habitat & $\begin{array}{c}\mathrm{N}^{\circ} \mathrm{de} \\
\text { capturas }\end{array}$ & $\begin{array}{c}\mathrm{N}^{\mathrm{o}} \mathrm{de} \\
\text { coletores }\end{array}$ & $\begin{array}{l}\text { Horas de } \\
\text { coleta por } \\
\text { captura }\end{array}$ & Total de Horas \\
\hline \multirow{4}{*}{$\begin{array}{c}\text { Aspirador a } \\
\text { bateria }\end{array}$} & Mata & 20 & 2 & 1 & $40 \mathrm{hrs}$ \\
\hline & Aberto & 20 & 2 & 1 & $40 \mathrm{hrs}$ \\
\hline & Peridomicílio & 20 & 1 & 1 & $20 \mathrm{hrs}$ \\
\hline & Intradomicílio & 20 & 1 & 1 & $20 \mathrm{hrs}$ \\
\hline \multirow{4}{*}{$\begin{array}{l}\text { Armadilha } \\
\text { CDC }\end{array}$} & Mata & 20 & 2 & 2 & $80 \mathrm{hrs}$ \\
\hline & Aberto & 20 & 2 & 2 & $80 \mathrm{hrs}$ \\
\hline & Peridomicilio & 20 & 1 & 2 & $40 \mathrm{hrs}$ \\
\hline & Intradomicilio & 20 & 1 & 2 & $40 \mathrm{hrs}$ \\
\hline $\begin{array}{l}\text { Armadilha } \\
\text { Shannon }\end{array}$ & Aberto & 20 & 2 & 1,5 & $60 \mathrm{hrs}$ \\
\hline
\end{tabular}


As capturas com aspirador foram realizadas nos períodos de manhã (11-12 hrs.)e tarde (14-15 hrs; 15- 16 hrs), correspondendo a uma hora em cada captura. Entretanto, as capturas com CDC e armadilha de Shannon, cobriram o horário crepuscular e um periodo após o crepúsculo, totalizando 2 horas para as primeiras e 1,5 horas para a segunda em cada captura. O horário crepuscular foi calculado utilizando-se do Almanaque Náutico (Marinha do Brasil, 1996, 1997, 1998) para a latitude e período correspondentes. As capturas com aspirador a bateria e com CDC exploraram os diversos habitats pesquisados.

Um total de 20 idas ao campo para coletas foram realizadas, sendo mensalmente esquematizadas para a primeira terça feira de cada mês.Todas as capturas foram registradas em fichas de campo codificadas, resumindo data, horário, habitat e técnica (Anexo 1).

\subsection{Transporte e Identificação de mosquitos:}

Os espécimes coletados foram mortos em clorofórmio e transferidos para caixas entomológicas, mantidos em freezer $\left(-40^{\circ} \mathrm{C}\right)$ até serem transportados ao laboratório de Entomologia da FSP-USP.

A identificação desses mosquitos foi realizada utilizando-se descrições e chaves taxonômicas (LANE 1953; FORATTINI 1965 ; FARAN e LINTHICUM 1980 ; LINTHICUM 1988; SALLUM 1994) e confronto com o material padrão. A identificação foi registrada em fichas de laboratório, contendo dados codificados correspondentes à espécie, ao sexo e quantidade (Anexo 2). Após a identificação, uma pequena amostra foi montada e depositada na Coleção Entomológica da Faculdade de Saúde Pública da USP (Anexo 3).

\subsection{Levantamento de dados meteorológicos}

Dados de pluviosidade média mensal (milimetros de chuva) e temperatura do ar média mensal $\left({ }^{\circ} \mathrm{C}\right)$, foram levantados para a Estação de Guarulhos, para o periodo pesquisado (Estação Meteorológica da Empresa Brasileira de Infra-estrutura 
Aeroportuária ). Esses dados foram utilizados na tentativa de explicação da distribuição mensal das espécies mais abundantes.

4.4 Processamento dos dados:

Com os dados levantados nas fichas de campo e laboratório, montou-se um banco de dados utilizando-se do Programa DbaseIII.(Anexo 4) Para o processamento desses dados, utilizou-se de Programas de SPSS- PC, Excel, Windows, Power Point (Anexo 5):

\subsubsection{Cálculo das Médias Horárias:}

As Médias horárias ( $\mathbf{X h}$ ) foram calculadas pela relação do total de culicídeos coletados segundo habitat, técnicas de coleta utilizadas e o total de horas gastas no período pesquisado respectivamente.

\subsection{2 Índice de Abundância:}

Para estimar a abundância numérica e distribuição espacial de cada uma das espécies de culicideos coletados com armadilhas CDCs, calculou-se o Índice de Abundância de especie (IAE), conforme ROBERTS e HSI (1979). Para se calcular esse indice, organizam-se os dados em uma planilha dispondo-se espécies por ambiente de coleta. Prenchem-se as células com os valores numéricos representados pela quantidade de espécimens capturados. A partir da tabela original, gera-se uma segunda tabela onde os valores numéricos são transformados em posições. Dessa forma, para cada ambiente de coleta teremos o ordenamento das espécies segundo a posição conseqüente de sua quantidade:

$$
\mathbf{I A E}=\mathbf{a}+\mathbf{R J} / \mathbf{K}
$$

Onde:

$$
\begin{aligned}
& \mathbf{a}=\text { número de células brancas } \times \mathrm{C} \text { (posição mais alta }+1) \\
& \mathbf{R J}=\text { somatória das posições por espécie }
\end{aligned}
$$


$\mathbf{K}=$ número de sitios ou ambientes de coleta

A padronização dos valores do IAE, para uma escala entre 0 e 1, realizou-se através da obtenção do Índice de Abundância de Espécie Padronizado (IAEP) conforme a relação apresentada a seguir:

\section{IAEP = C - IAE $/ C-1$}

Onde:

$\mathrm{C}=$ Posição mais alta +1 .

$\mathbf{I A E}=$ Índice de Abundância de Espécies.

4.4.3 Índice de Diversidade:

Para avaliar a diversidade de espécies nos diversos habitats, foi calculado o Indice de Diversidade (IDv) para as espécies coletadas com armadilhas CDCs, conforme Margalef (1954) (citados por SERVICE, 1993). Segundo a fórmula a seguir:

$$
\text { IDv }=S-1 / \log _{e} N
$$

Onde

$\mathbf{S}=$ número de espécies

$\mathbf{N}=$ numero de individuos

\subsection{4 Índice de Dominância:}

Para se conhecer a dominância das espécies, calculou-se o Índice de Dominância (IDo) de acordo com Barber-Parker (citado por SOUTHWOOD, 1978)

$$
\text { IDo }=\text { Nmax/Ntotal } x 100
$$

Onde

$\mathbf{N m a x}=$ número de espécimens capturados da espécie mais freqüente

Ntotal $=$ total de especimens coletados para todas as espécies 


\subsection{5 Índice de Sinantropia:}

Para estimar os niveis de associação das espécies de culicídeos com o ambiente urbano, optou-se pelo Índice de Sinantropia (IS) proposto por Nuorteva, 1963, já utilizado por FORATTINI, 1993 para culicideos. Calculou-se o índice para as espécies coletadas com armadilhas $\mathrm{CDCs}$, conforme a fórmula a seguir:

$$
I S=\underline{2 a(\%)+b(\%)-2 c(\%)}
$$

2

Onde

$\mathbf{a}=\%$ de espécimens de uma dada espécie coletada em área intradomiciliar e peridomiciliar em relação ao total coletado nos três ambientes estudados.

$\mathbf{b}=\%$ de espécimens da mesma espécie coletada em área de vegetação aberta.

$\mathbf{c}=\%$ de espécimens da mesma espécie coleta em ambiente de mata residual.

$\mathrm{O}$ indice de sinantropia varia de -100 indicando a não associação com o ambiente humano para +100 , indicando completa distribuição urbana.

\subsubsection{Quociente de Similaridade.}

O Quociente de Similaridade (QS) de SORENSEN (1948) ou Índice de CZEKANOWSKI'S, citado por SERVICE, (1993) foi calculado para comparar a distribuição de espécies nos ambientes pesquisados; conforme a fórmula a seguir:

$$
\mathbf{Q S}=\mathbf{2} \mathbf{J} / \mathbf{a}+\mathbf{b}
$$

Onde:

$\mathbf{J}=$ número de espécies que ocorrem nas duas coletas simultaneamente. 
$\mathbf{a}+\mathbf{b}=$ Número espécies encontradas em ambas coletas separadamente.

4.4.7 Detecção de sangue de primatas.

Existem diversas técnicas para identificar fontes de sangue em mosquitos; entre elas, a técnica de precipitina é muito utilizada. Além dessa, técnicas inmunoenzimáticas foram também desenvolvidas (WEITZ 1956 ; WASHINO e TEMPELIS, 1983 ; BURKOT e DEFOLIART, 1981).

Nesse trabalho, utilizou-se a técnica de precipitina (tubo capilarmicrohematócrito ) (TEMPELIS \& LOFY, 1963). Dos espécimens coletados com armadilhas CDCs, selecionou-se um "pool" de mosquitos que se encontravam em estado de ingurgitamento (" bem ingurgitado "). Os espécimens assim selecionados foram testados pela técnica já mencionada. Nesse teste, utilizaram-se de antisoro antihumano (inmunoglobulinas; IgG, IgM, IgA) do laboratório SIGMA. Optou-se por testar um número constante de representantes de cada uma das espécies. No entanto, espécimens das espécies menos freqüentes foram testados em número menor.

Calculou-se o Índice de Positividade para o Sangue de Primatas (IPSP) para cada uma das espécies testadas, conforme a fórmula a seguir:

Onde

$$
\text { IPSP }=\mathrm{EP} / \mathrm{ET} \times 100
$$

$\mathbf{E P}=$ Número de espécimens de uma dada espécie positivos ao teste de precipitina

$\mathbf{E T}=$ Número de espécimens de uma dada espécie testados

\subsubsection{Freqüência domiciliar e atividade horária:}

Para avaliar a freqüência de espécies ao ambiente domiciliar, realizaram-se coletas de 24 horas ininterruptas, com isca luminosa e atrativo humano, utilizando-se de 
aspirador elétrico em ambiente peridomiciliar. Optou-se por realizar uma coleta por estação do ano, totalizando quatro coletas. Nas capturas, optou-se por duplas de coletores que permaneciam por um periodo de 3 horas consecutivos. As capturas iniciavam-se às 11 horas e terminavam às 11 horas do dia seguinte. Por medida de segurança, os coletores estavam vestidos com blusas de mangas cumpridas e botas altas de borracha

Calculou-se o Índice de Picada / Homem / Hora (IPHH) das espécies mais freqüentes, conforme a fórmula a seguir:

\section{IPHH $=\mathbf{N m h} / \mathrm{Ncol} / \mathrm{NTc}$}

Onde

$\mathbf{N m h}=$ Número de mosquitos capturados por hora.

Ncol= Número de coletores

NT $\mathbf{c}=$ Número total de coletas naquela hora .

Para calcular à atividade horária, adotou-se a média de Williams (Xw) para essas espécies, segundo Haddow $(1954,1960)$ conforme a fórmula a seguir:

$$
X w(e, i)=\{(X e, i, j / C i j+1)\}^{1 / m}-1
$$

Onde:

$\mathbf{X W}(\mathrm{e}, \mathrm{i})=$ média referente à espécie e e no intervalo $\mathbf{i}$

$\mathbf{X} \mathbf{e}, \mathbf{i}, \mathbf{j}=$ número de espécimens da espécie $\mathbf{e}$, coletados na captura $\mathbf{j}$ realizada no intervalo de tempo $\mathbf{i}$

$\mathbf{m}=$ numero de capturas realizadas no intervalo de tempo $\mathbf{i}$.

$\mathrm{Ci}, \mathrm{j}=$ número de indivíduos capturadores empregados na captura $\mathbf{j}$ realizada no intervalo de tempo $\mathbf{i}$

4.4.9 Distribuição mensal das espécies mais abundantes

Para se conhecer a distribuição mensal das espécies mais abundantes, calculouse a Xw (média de Williams) conforme a fórmula citada anteriormente. 
4.4.10 Cálculo do coeficiente de correlação

Para explicar a correlação da atividade mensal das espécies mais freqüentes com a pluviosidade e a temperatura, calculou-se o coeficiente de correlação de Pearson (citado por SOUNIS, 1985), para as referidas espécies, coletadas com aspirador a bateria, conforme a formula a seguir:

$$
r=\Sigma(X Y) / N \cdot \sigma_{x} \cdot \sigma_{y}
$$

Onde:

$r=$ coeficiente de correlação

$\mathrm{N}=$ total de pares de observações

$\Sigma(\mathrm{XY})=$ somatória dos produtos dos desvios a partir dos valores médios das variáveis $\mathrm{X}$ e $\mathrm{Y}$

$\sigma_{\mathrm{x}}=$ desvio padrão de $\mathrm{X}$

$\sigma_{y}=$ desvio padrão de $\mathrm{Y}$

Para testar a significância estatística do coeficiente de correlação (r), utilizou-se da razão "t" de Student, sendo o nivel de significância de $(\alpha=0,05)$ com ( $n-2)$ graus de liberdade, conforme a fórmula a seguir:

$$
t=r \sqrt{ } n-2 / \sqrt{ } 1-r^{2}
$$

Onde:

$$
\begin{aligned}
& t=\text { razão } t(t \text { observado, calculado para testar a significância de } r \text { ) } \\
& n=\text { número de pares de escores }(\text { de } x \text { e y ) } \\
& r=\text { coeficiente de correlação de Pearson. }
\end{aligned}
$$

Utilizou-se também do software SPSS para o cálculo de coeficiente de correlação (r) e a probabilidade $(\mathbf{p})$ 


\section{RESULTADOS E DISCUSÃO}

\subsection{Freqüência espacial e temporal de culicídeos}

Coletaram-se 53.496 espécimes de culicídeos (Tabela 1), como consta na tabela $75,7 \%$ desses foram fêmeas e $24,3 \%$ machos. Na mesma tabela estão dispostas as 25 espécies ou grupos genéricos coletadas. As espécies aqui identificadas já foram assinaladas em trabalho anterior na área por SOUBIHE 1995. Na presente pesquisa, embora a composição da fauna não tenha-se alterado, quando se compara com o trabalho anterior, as freqüências das espécies mostraram-se bastante distintas. (Tabela 1 Fig 20).

SOUBIHE em 1995 assinalara Ma titillans como espécie mais freqüente $(31,4 \%)$ no Parque. Nesse trabalho, a mencionada espécie atingiu apenas $0,5 \%$. Essa situação pode estar condicionada à falta de oferta de criadouros para essa espécie. $\mathrm{Na}$ época em que foi conduzido o trabalho de SOUBIHE (1992-1993), as margens do Rio Tietê estavam cobertas de aguapé o qual, anos depois, diminuíu por efeito de dragagem e rebaixamento do leito do Rio, reduzindo-se dessa forma os criadouros desses mosquitos. Os efeitos da referida intervenção explicam a freqüência baixa atual dessa espécie, pois a vegetação de aguapés foi bastante restringida no Parque. Em compensação, há no local extensas áreas abertas e planas que, mediante a ação das chuvas, propiciam a formação de numerosos criadouros temporários de Ae. scapularis, que foi, no presente trabalho, a espécie mais freqüente (Tabela. 1)

As frequèncias de Ae. scapularis, Cx quinquefasciatus e Cx. declarator registradas por SOUBIHE em 1995 atingiram ao 7,7\%, 4,8\% e 3,0\% respectivamente. Nesse trabalho, as mencionadas espécies foram as mais freqüentes. A alteração do hábitat das Mansonias, pode ter favorecido a dominância das espécies assinaladas. 
Tabela 1. Frequência de Culicídeos no Parque Ecológico do Tietê Guarulhos. Estado de São Paulo. no periodo de 1996 a 1998.

\begin{tabular}{|c|c|c|c|c|c|c|}
\hline \multirow[t]{2}{*}{ Categorias Taxonômicas } & \multicolumn{2}{|c|}{ Macho } & \multicolumn{2}{|c|}{ Fémea } & \multirow[t]{2}{*}{$N^{\circ}$} & \multirow[t]{2}{*}{$\%$} \\
\hline & $\mathbf{N}^{\circ}$ & $\%$ & $\mathbf{N}^{\circ}$ & $\%$ & & \\
\hline Ae. scapularis & 5980 & 46,3 & 26050 & 64,3 & 32030 & 60,0 \\
\hline$C x_{.}(C u x$.$) quinquefasciatus$ & 6026 & 46.4 & 8522 & 21,0 & 14548 & 27,2 \\
\hline$C x .(C u x$.$) declarator$ & 890 & 6.9 & 3821 & 9.5 & 4711 & 8.8 \\
\hline$C x .(C u x)$ sp.gr.coronator & 42 & 0,3 & 645 & 1.6 & 687 & 1.3 \\
\hline Ma. (Man.) indubitans & 8 & 0.0 & 565 & 1.4 & 573 & 1.0 \\
\hline Cq. venezuelensis & 1 & 0.0 & 322 & 0.8 & 323 & 0.6 \\
\hline Ma. (Man.) titillans & 2 & 0.0 & 268 & 0.7 & 270 & 0.5 \\
\hline An. strodei & 7 & 0.0 & 70 & 0.2 & 77 & 0.1 \\
\hline Cx. (Cux.) chidesteri & 8 & 0.0 & 45 & 0.1 & 53 & 0.1 \\
\hline An. albitarsis & 1 & 0.0 & 50 & 0.1 & 51 & 0.1 \\
\hline Ae. albopictus & 5 & 0.0 & 36 & 0.1 & 41 & 0.1 \\
\hline An. evansae & 2 & 0.0 & 27 & 0,1 & 29 & 0.1 \\
\hline Ps. ferox & 5 & 0.0 & 24 & 0.1 & 29 & 0.1 \\
\hline$C x$ (MeL) gr.pilosus & 1 & 0.0 & 12 & 0.0 & 12 & 0.0 \\
\hline Cx. (Mel.) seção Melanoconion & 14 & 0.1 & 12 & 0.0 & 13 & 0.0 \\
\hline Ma. (Man.) sp. & - & - & 3 & 0.0 & 17 & 0.0 \\
\hline$C x .(M e l$.$) ribeirensis$ & - & - & 6 & 0.0 & 6 & 0.0 \\
\hline Ps. discrucians & - & - & 5 & 0,0 & 5 & 0.0 \\
\hline Ae. fluviatilis & 1 & 0.0 & 4 & 0.0 & 5 & 0.0 \\
\hline$C x$ (Cux) nigripalpus & - & - & 4 & 0.0 & 4 & 0.0 \\
\hline$C x .(C u x)$ brethesi & - & - & 4 & 0.0 & 4 & 0.0 \\
\hline Ps. ciliata & - & - & 3 & 0.0 & 3 & 0.0 \\
\hline Cx. (Cux.) bidens & 1 & 0.0 & 2 & 0.0 & 3 & 0.0 \\
\hline Cx. (Cux.) mollis & - & - & 1 & 0.0 & 1 & 0.0 \\
\hline Ur. lowii & - & - & 1 & 0.0 & 1 & 0.0 \\
\hline TOTAL & 12994 & 100.0 & 40502 & 100.0 & 53496 & 100.00 \\
\hline
\end{tabular}




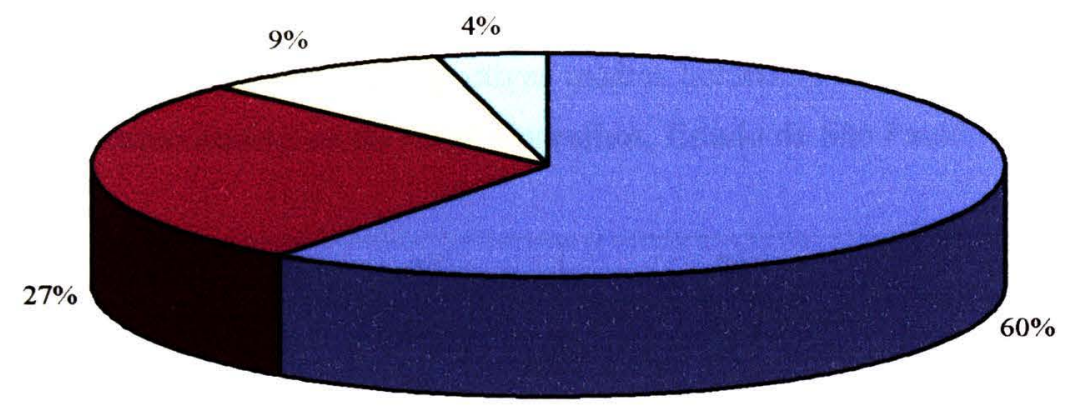

$$
\text { Ae.scapularis DCx.quinquefasciatus aCx.declarator 口Outros }
$$

Figura 20. Culicídeos mais freqüentes no Parque Ecológico do Tietê, Guarulhos, São Paulo, 1996-1998.

Considerou-se espécie mais freqüente aquela que apresentou acima de $5 \%$ de freqüência no período estudado. Assinala-se que, cerca de $96 \%$ dos culicídeos identificados foram representados por três espécies: Aedes scapularis (60,0\%), Culex quinquefasciatus (27,2\%) e Culex declarator (8,8\%) (Tabela 1). A expressividade desses resultados mereceu destacar Ae. scapularis, levando-se em consideração seu reconhecido papel na transmissão de arbovírus e outras parasitoses. Entretanto, entre as espécies com potencial epidemiológico, Aedes albopictus atingiu apenas $(0,08 \%)$. Embora com menor freqüência ainda, Culex nigripalpus, Psorophora ferox, Culex ribeirensis foram também registradas no Parque.

Com base no que foi descrito na metodologia, relativo ao total de horas utilizadas nas coletas segundo as três técnicas, calcularam-se as médias horárias (Xh) do total de culicídeos para cada técnica, registrando-se que, o maior número desses mosquitos foi capturado com aspiradores à bateria $(X \mathbf{h}=237,8)$, seguida por armadilha de Shannon $(\mathbf{X h}=86,0)$, que operou somente em ambiente aberto. As coletas com armadilhas CDC atingiram a $\mathbf{X h}=82,4$ (Tabela 2, Fig 21).

Devido ao elevado rendimento da coleta não atrativa, representada pelo aspirador à bateria $(53,4 \%)$, fica evidente que os mosquitos coletados em ambiente aberto se abrigam na vegetação rasteira, que é usada como ambiente de repouso desses mosquitos. Esse fato pode contribuir com o processo de domiciliação de algumas espécies. Essa hipótese é concordante com a assinalada por (FORATTINI 1965; LOPES \& LOZOVEI 1995). 
Tabela 2. Distribuição de freqüência das respectivas médias horárias(Xh) de Culicídeos coletados com as diversas técnicas no Parque Ecológico do Tietê, Guarulhos, Estado de São Paulo, 1996 a 1998.

\begin{tabular}{|c|c|c|c|}
\hline Técnica & $\mathrm{N}^{\circ}$ & $\%$ & $\mathrm{Xh}$ \\
\hline Aspirador & 28547 & 53,4 & 237,8 \\
\hline Shannon & 5162 & 9,6 & 86,0 \\
\hline CDC & 19787 & 37,0 & 82,4 \\
\hline Total & 53496 & 100,0 & 127,3 \\
\hline
\end{tabular}

$\mathbf{X h}=$ Média horária.

Nota-se que, com as três modalidades de captura, registrara-se o predomínio de Ae. scapularis, Cx. quinquefasciatus e Cx. declarator (Tabela 3, Fig 22).

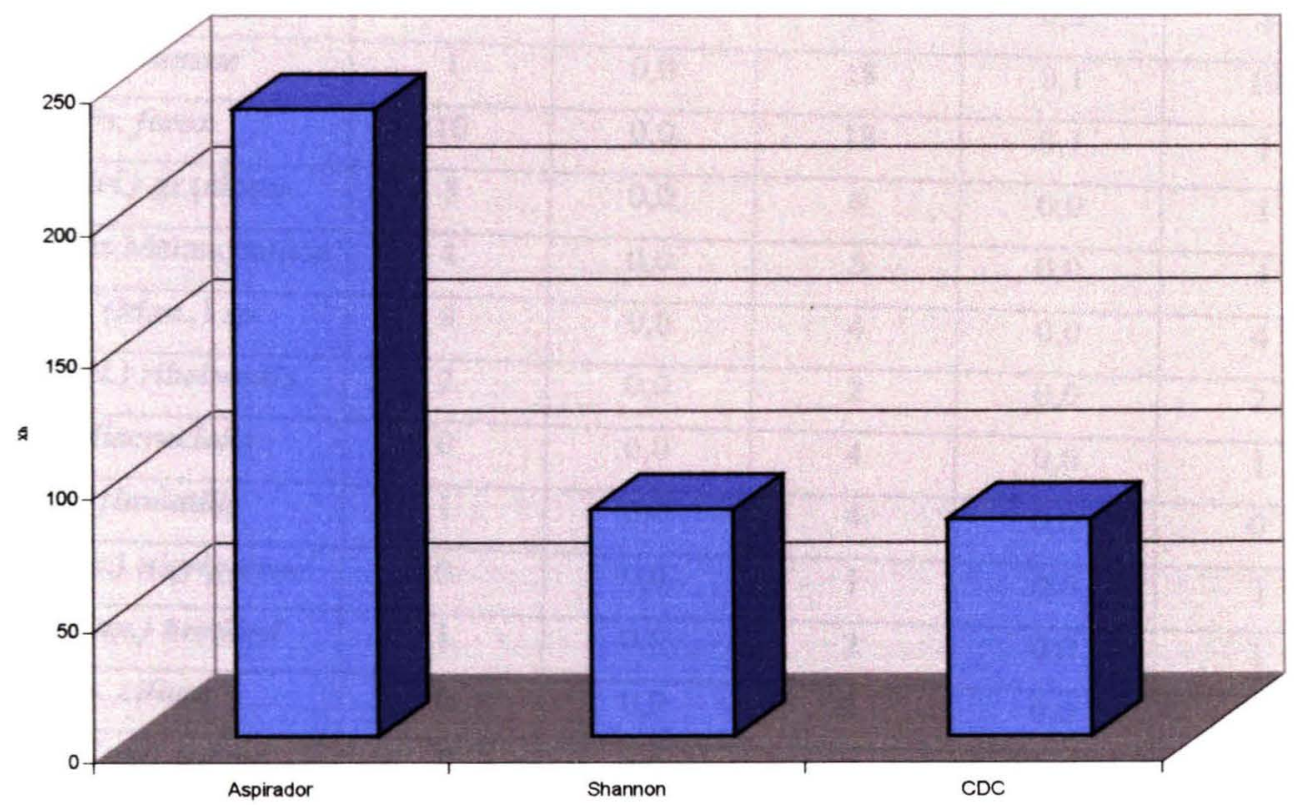

Figura 21. Médias horárias de culicídeos segundo técnica no Parque Ecológico doTietê, Guarulhos, São Paulo, 1996 - 1998 
Tabela 3. Freqüência de culicídeos segundo a técnica de coleta. Parque Ecológico do Tietê. Guarulhos. Estado de São Paulo. no período de 1996 a 1998.

\begin{tabular}{|c|c|c|c|c|c|c|}
\hline \multirow{2}{*}{ Categorias Taxonômicas } & \multicolumn{2}{|c|}{ Aspirador } & \multicolumn{2}{|c|}{$\mathrm{CDC}$} & \multicolumn{2}{|c|}{ Shannon } \\
\hline & $N^{\circ}$ & $\%$ & $N^{\circ}$ & $\%$ & $\mathbf{N}^{\circ}$ & $\%$ \\
\hline Ae scapularis & 14691 & 51,4 & 14492 & 73,2 & 3106 & 60.1 \\
\hline Cx. quinquefasciatus & 11515 & 40,3 & 2360 & 12,0 & 414 & 8.0 \\
\hline Cx. declarator & 1907 & 6,7 & 1726 & 9.0 & 1078 & 21.0 \\
\hline$C x$. gr. coronator & 203 & 0,8 & 373 & 2,0 & 111 & 2.1 \\
\hline Ma indubitans & 57 & 0,2 & 204 & 1,0 & 312 & 6.0 \\
\hline Cq. venezuelensis & 3 & 0,0 & 292 & 1,4 & 28 & 0.5 \\
\hline Ma. titillans & 68 & 0,3 & 149 & 0,8 & 53 & 1.0 \\
\hline An. strodei & 5 & 0,0 & 54 & 0.2 & 17 & 0.4 \\
\hline$C x$ chidesteri & 23 & 0.1 & 25 & 0,1 & 5 & 0.2 \\
\hline An. albitarsis & 13 & 0,0 & 29 & 0.1 & 9 & 0.1 \\
\hline Ae. albopictus & 28 & 0.1 & 12 & 0,0 & 1 & 0.0 \\
\hline An. evansae & 1 & 0.0 & 18 & 0,1 & 10 & 0.2 \\
\hline Ps. ferox & 10 & 0,0 & 18 & 0,1 & 1 & 0.0 \\
\hline$C x(M e l)$ gr.pilosus & 5 & 0,0 & 6 & 0,0 & 1 & 0.0 \\
\hline$C x$ (MeL)s Melanoconion & 4 & 0,0 & 5 & 0,0 & 4 & 0.1 \\
\hline Ma. (Man..) sp & 9 & 0.0 & 4 & 0.0 & 4 & 0.1 \\
\hline Cx (Mel.) ribeirensis & 2 & 0.0 & 2 & 0.0 & 2 & 0.0 \\
\hline Ps. discrucians & 0 & 0.0 & 4 & 0,0 & 1 & 0.0 \\
\hline Ae. fluviatilis & 1 & 0.0 & 4 & 0,0 & 0 & 0.0 \\
\hline$C x_{0}$ (Cux.) nigripalpus & 0 & 0.0 & 1 & 0.0 & 3 & 0.1 \\
\hline$C x$ (Cux.) brethesi & 1 & 0,0 & 2 & 0.0 & 1 & 0,0 \\
\hline Ps. ciliata & 0 & 0,0 & 2 & 0,0 & 1 & 0,0 \\
\hline$C x .(C u x)$ bidens & 1 & 0,0 & 2 & 0,0 & 0 & 0.0 \\
\hline$C x$ (Cux) mollis & 0 & 0.0 & 1 & 0,0 & 0 & 0,0 \\
\hline Ur. lowii & 0 & 0,0 & 1 & 0,0 & 0 & 0.0 \\
\hline TOTAL & 28547 & 100.0 & 19787 & 100,0 & 5162 & 100.0 \\
\hline
\end{tabular}




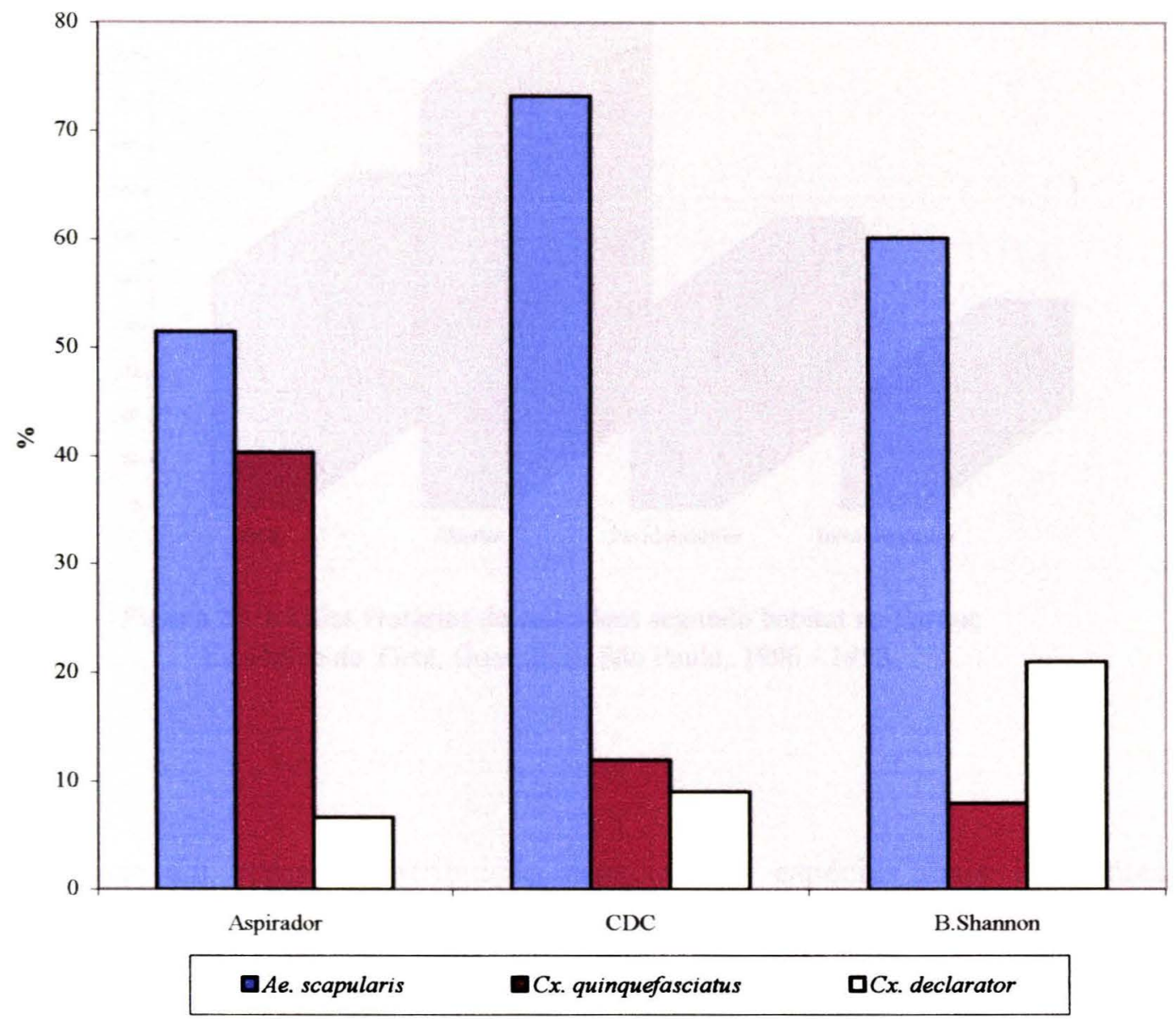

Figura 22. Culicídeos mais freqüentes segundo técnica de coleta no Parque Ecológico do Tietê, Guarulhos, São Paulo, 1996- a 1998.

Calcularam-se as médias horárias (Xh) de culicídeos coletados nos diversos habitats. Nota-se que o maior número desses mosquitos foi coletado no ambiente aberto $(\mathrm{Xh}=185,7)$. Nas capturas nesse ambiente, foram coletados $62,5 \%$ dos espécimes dessa pesquisa. (Tabela 4, Fig 23).

Tabela 4. Distribuição de frequiência e respectivas médias horárias (Xh) de culicídeos coletados nos diversos habitats no Parque Ecológico do Tietê, Guarulhos, São Paulo, 1996 a 1998.

\begin{tabular}{|c|c|c|c|}
\hline Habitat & $\mathbf{N}^{\circ}$ & $\%$ & Xh \\
\hline Mata & 12327 & 23,0 & 102,7 \\
\hline Aberto & 33428 & 62,5 & 185,7 \\
\hline Peridomicílio & 4976 & 9,3 & 82,9 \\
\hline Intradomicílio & 2765 & 5,2 & 46,0 \\
\hline Total & 53496 & 100,0 & 127,3 \\
\hline
\end{tabular}

$\mathrm{Xh}=$ Média horária. 


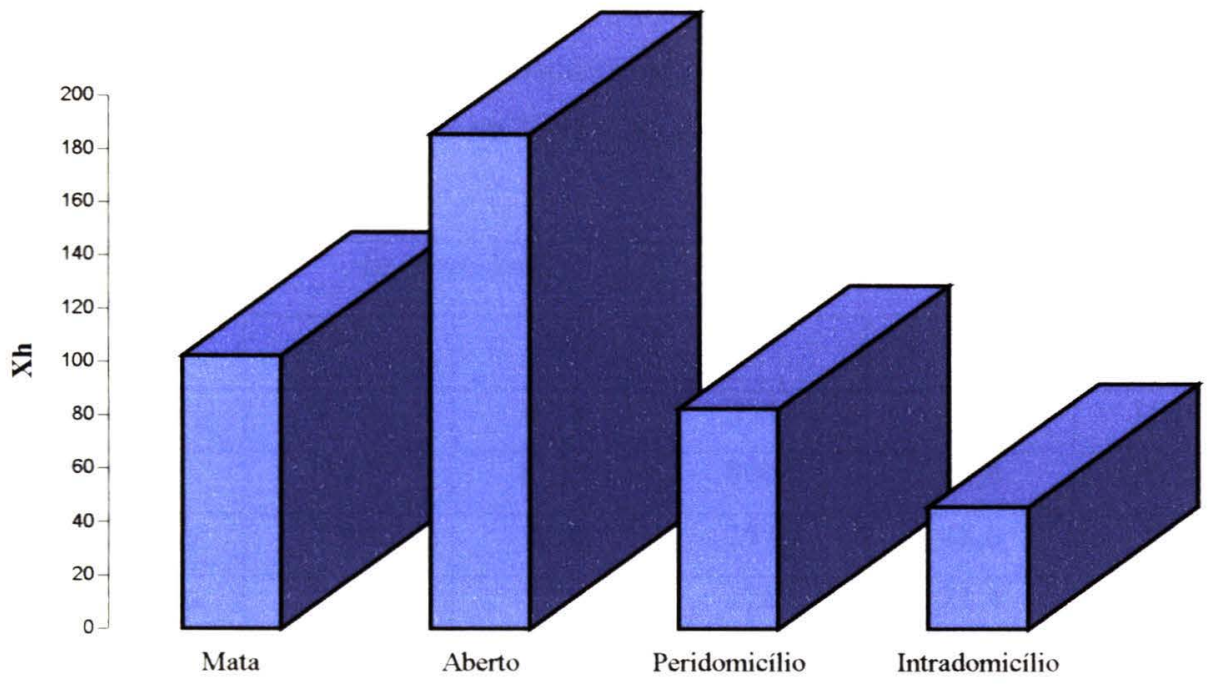

Figura 23. Médias Horárias de culicídeos segundo habitat no Parque Ecológico do Tietê, Guarulhos, São Paulo, 1996 - 1998.

Levando-se em conta a distribuição espacial das espécies mais freqüentes, Aedes scapularis prevaleceu no ambiente aberto $(\mathbf{X h}=118,9)$ e mata $(\mathbf{X h}=64,8)$; esteve presente em ambiente peridomiciliar $(\mathbf{X h}=25,0)$ e intradomiciliar $(\mathbf{X h}=22,3)$. Por sua vez, $C \boldsymbol{x}$. quinquefasciatus esteve mais presente em ambiente peridomiciliar (Xh = $48,6)$, presente no intradomicílio $(\mathbf{X h}=21,4) . \quad C x$. declarator apresentou maior freqüência no aberto $(\mathbf{X h}=14,0)$. (Tabela 5 Fig 24).

A predominância de $A$ e. scapularis em ambiente aberto e/ou áreas modificadas registrada no Parque, foi constatada em observações relatadas na América Latina, por MITCHELL e col., 1985 na Argentina, e ROBERTS e col., 1985 na Bolivia. Na literatura nacional semelhantes observações foram feitas em área de vegetação secundária ( FORATTINI e col., 1968, 1978, 1978a, 1981, 1986, 1987, 1989, 1995 ; LOURENÇO DE OLIVEIRA 1984; FORATTINI \& GOMES 1988; CASANOVA 1994; MARQUES 1994; BRUNO 1997; MENEZES 1997 ). 
Tabela 5. Distribuição dos números e respectivas médias horárias de culicídeos mais freqüentes nos diversos habitats no Parque Ecológico do Tietê, São Paulo, 1996 a 1998.

\begin{tabular}{|c|c|c|c|c|c|c|}
\hline \multirow{2}{*}{ Habitat } & \multicolumn{2}{|c|}{ Ae.scapularis } & \multicolumn{2}{c|}{ Cx. quinquefasciatus } & \multicolumn{2}{c|}{ Cx. declarator } \\
\cline { 2 - 7 } & $\mathrm{N}^{\circ}$ & $\mathrm{Xh}$ & $\mathrm{N}^{\circ}$ & $\mathrm{Xh}$ & $\mathrm{N}^{\circ}$ & $\mathrm{Xh}$ \\
\hline Mata & 7776 & 64,8 & 2343 & 19,5 & 1619 & 13,4 \\
\hline Aberto & 21413 & 118,9 & 8004 & 44,4 & 2523 & 14,0 \\
\hline Peridomicilio & 1500 & 25,0 & 2916 & 48,6 & 501 & 8,3 \\
\hline Intradomicílio & 1341 & 22,3 & 1285 & 21,4 & 68 & 1,1 \\
\hline Total & 32030 & 76,2 & 14548 & 34,6 & 4711 & 11,2 \\
\hline
\end{tabular}

$\mathrm{Xh}=$ Média horária.

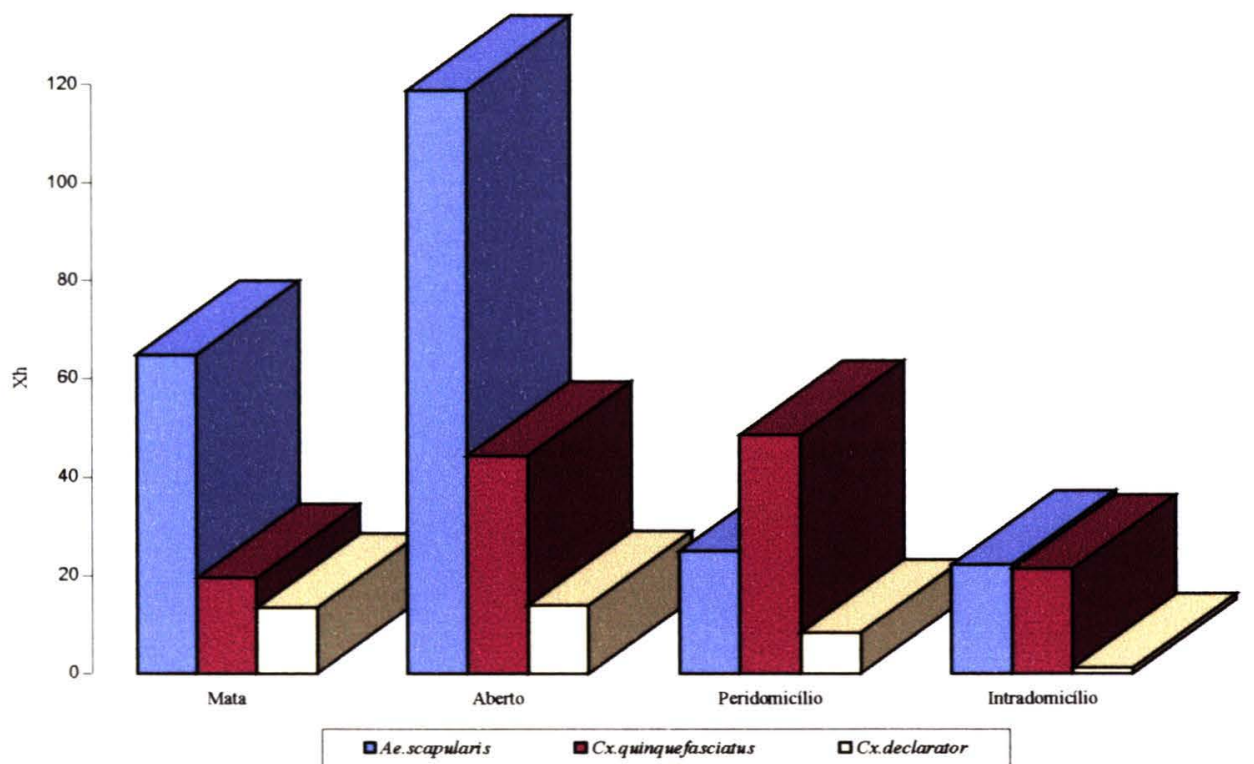

Figura 24. Médias horárias de culicídeos mais freqüentes segundo habitat no Parque Ecológico do Tietê,Guarulhos, São Paulo.1996-1998.

Quanto à distribuição espacial avaliada através da freqüência as três espécies mais freqüentes estiveram presentes nos ambientes pesquisados. Aedes scapularis predominou em ambiente de mata e vegetação aberta $(63,2 \%$ e $64,1 \%)$. No entanto, mereceu atenção a freqüência desse mosquito em ambiente intradomiciliar $(48,6 \%)$, o que sugere sua tendência endofila (Tabela 6, Fig 25).

A tendência endofilica de Ae. scapularis foi assinalada por diversos autores, (FORATTINI, 1961; FORATTINI e col, 1981, 1986, 1987 ${ }^{\mathrm{a}}$, 1995; LOURENÇO DE OLIVEIRA 1984; LOURENÇO DE OLIVEIRA e HEYDEN 1986; MENEZES 1997; BRUNO 1997). Nesse trabalho, registraram-se mais espécimes desse mosquito em ambiente 
peridomiciliar em relação ao intradomicílio. FORATTINI e col., em 1995 não encontraram diferenças na presença desse mosquito entre esses ambientes.

Cx. quinquefasciatus predominou em ambiente domiciliar (58,7\% e 46,6\%). Por sua vez, $C x$. declarator atingiu apenas (10,2\% e 2,5\%) em ambiente domiciliar, sendo mais presente na mata (13\%) (Fig 25). Em adição, Ma titillans, Ma indubitans, Cq. venezuelensis, Ae. albopictus, $\mathrm{Cx}$. chidesteri $e \mathrm{Cx}$. ribeirensis estavam freqüentando o ambiente domiciliar. (Tabela 6) . 
Tabela 6. Freqüencia de culicídeos segundo habitat de coleta. Parque Ecológico do Tietê. Guarulhos. Estado de São Paulo. no periodo de 1996 a 1998.

\begin{tabular}{|c|c|c|c|c|c|c|c|c|}
\hline Categorias Taxonômicas & $\begin{array}{l}\text { Mata } \\
\mathrm{N}^{\mathrm{o}}\end{array}$ & $\begin{array}{c}\text { Mata } \\
\%\end{array}$ & $\begin{array}{c}\text { Aberto } \\
N^{o}\end{array}$ & $\begin{array}{c}\text { Aberto } \\
\%\end{array}$ & $\begin{array}{c}\text { Perido. } \\
\mathrm{N}^{\mathrm{o}}\end{array}$ & $\begin{array}{c}\text { Perido. } \\
\%\end{array}$ & $\begin{array}{c}\text { Intrado. } \\
\mathbf{N}^{\circ}\end{array}$ & $\begin{array}{c}\text { Intrado. } \\
\%\end{array}$ \\
\hline Ae. scapularis & 7776 & 63.2 & 21413 & 64,1 & 1500 & 30,1 & 1341 & 48,6 \\
\hline Cx.(Cux) quinquefasciatus & 2343 & 19.0 & 8004 & 24.0 & 2916 & 58.7 & 1285 & 46.6 \\
\hline Cx. (Cux) declarator & 1619 & 13.0 & 2523 & 7,5 & 501 & 10.2 & 68 & 2.5 \\
\hline Cx. (Cux.) gr.coronator & 251 & 2.0 & 434 & 1.3 & 2 & 0.0 & 0 & 0.0 \\
\hline Ma. (Man.) indubitans & 118 & 1.0 & 425 & 1,3 & 17 & 0,3 & 13 & 0.5 \\
\hline Cq. venezuelensis & 84 & 0.8 & 213 & 0.5 & 10 & 0.2 & 16 & 0.8 \\
\hline Ma. (Man.) titillans & 61 & 0.5 & 186 & 0.5 & 13 & 0.2 & 10 & 0,3 \\
\hline An. strodei & 12 & 0.1 & 63 & 0.2 & 1 & 0.0 & 1 & 0.0 \\
\hline$C x .(C u x)$ chidesteri & 18 & 0.1 & 27 & 0.1 & 2 & 0.1 & 6 & 0,1 \\
\hline An. albütarsis & 5 & 0.0 & 35 & 0.1 & 0 & 0.0 & 11 & 0.1 \\
\hline Ae. albopictus & 10 & 0.1 & 17 & 0.1 & 2 & 0.0 & 12 & 0,4 \\
\hline An. evansae & 7 & 0.1 & 22 & 0.1 & 0 & 0.0 & 0 & 0.0 \\
\hline Ps. ferox & 8 & 0.1 & 20 & 0.1 & 1 & 0,0 & 0 & 0,0 \\
\hline$C x .(M e l$.$) gr. pilosus$ & 2 & 0.0 & 10 & 0.0 & 0 & 0.0 & 0 & 0.0 \\
\hline Cx (Mel.)sec. Melanoconion & 1 & 0.0 & 12 & 0,0 & 0 & 0.0 & 0 & 0.0 \\
\hline Ma. (Man.) sp. & 2 & 0.0 & 10 & 0.0 & 3 & 0.1 & 2 & 0.1 \\
\hline$C x($ Mel.) ribeirensis & 0 & 0.0 & 4 & 0,0 & 2 & 0.0 & 0 & 0,0 \\
\hline Ps. discrucians & 0 & 0.0 & 5 & 0.0 & 0 & 0.0 & 0 & 0.0 \\
\hline Ae. fluviatilis & 3 & 0.0 & 1 & 0.0 & 1 & 0.0 & 0 & 0.0 \\
\hline$C x .(C u x$.$) nigripalpus$ & 2 & 0.0 & 2 & 0.0 & 0 & 0.0 & 0 & 0.0 \\
\hline Cx. (Cux.) brethesi & 1 & 0,0 & 2 & 0,0 & 1 & 0,0 & 0 & 0,0 \\
\hline Ps. ciliata & 1 & 0.0 & 2 & 0.0 & 0 & 0.0 & 0 & 0.0 \\
\hline$C x .(C u x)$ bidens & 1 & 0.0 & 1 & 0,0 & 1 & 0.0 & 0 & 0,0 \\
\hline Cx. (Cux.) mollis & 1 & 0.0 & 0 & 0.0 & 0 & 0.0 & 0 & 0.0 \\
\hline Ur. lowï & 1 & 0.0 & 0 & 0.0 & 0 & 0.0 & 0 & 0.0 \\
\hline TOTAL & 12327 & 100.0 & 33428 & 100.0 & 4976 & 100.0 & 2765 & 100.0 \\
\hline
\end{tabular}

Perido=peridomicilio: Intrado= intradomicilio. 


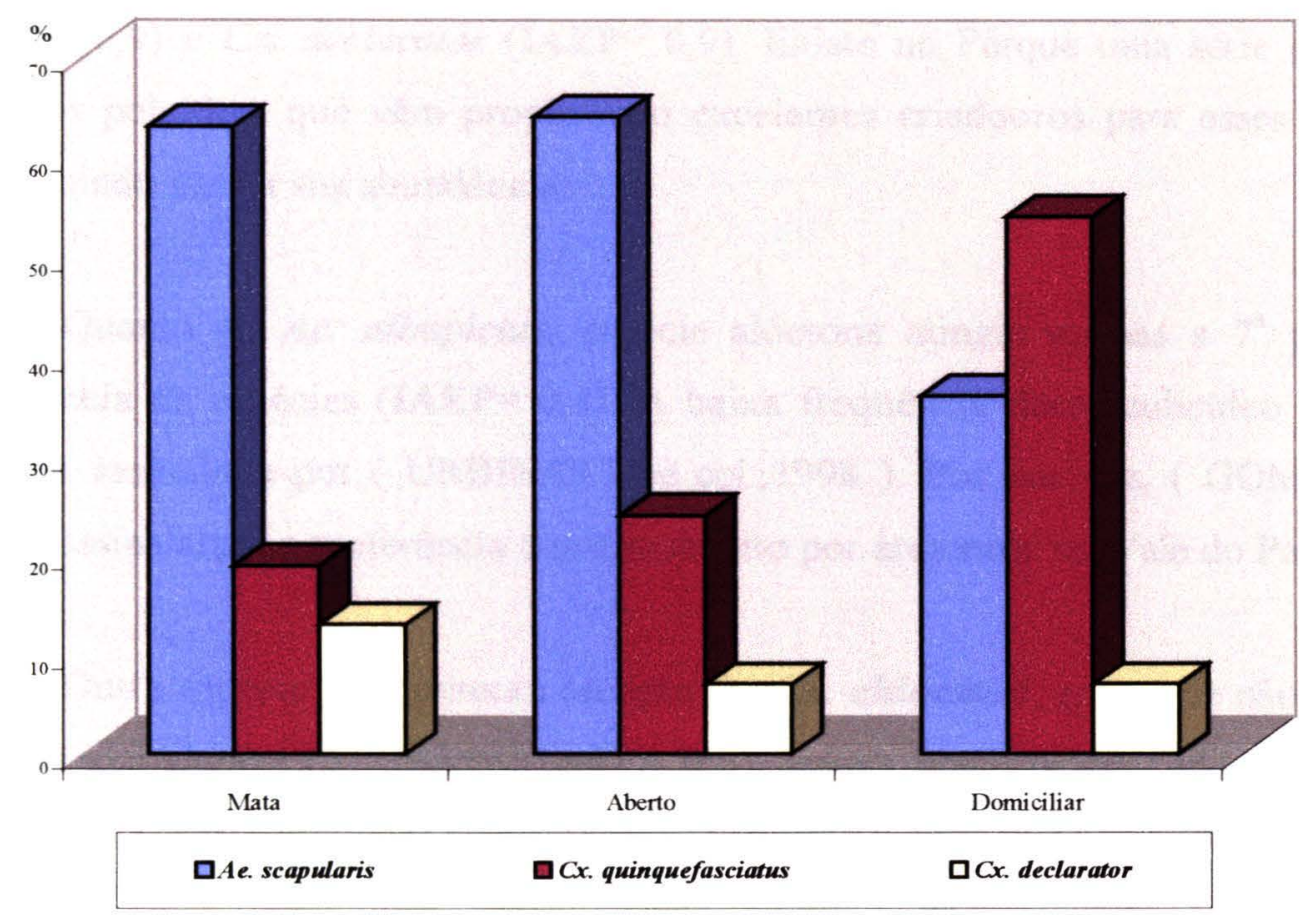

Figura 25. Culicídeos mais frequeêntes segundo habitat, Parque Ecológico do Tietê, Guarulhos, São Paulo, 1996-1998.

\subsection{Abundância numérica e espacial dos culicídeos.}

Conforme descrito na metodologia, estimou-se o Índice de Abundância de Espécies Padronizado (IAEP) segundo ROBERTS e HSI (1979). Esse índice foi estimado para culicídeos coletados com as armadilhas CDCs ( + gelo seco). (Tabela 7 Fig 26). Sendo assim, a espécie mais abundante foi Ae. scapularis (IAEP= 1,0). Autores como LOURENÇO DE OLIVEIRA (1984) CASANOVA (1994) FORATTINI e col.,(1995) TEODORO e col., (1995) assinalaram que, o poder competitivo desse mosquito está associado à ampliação dos locais de criação, sendo as áreas abertas lugares de proliferação.

No Parque Ecológico do Tietê, além de encontraram-se imensas áreas abertas associadas às matas residuais, sujeitas ao acúmulo de água na época de chuva, que formam criadouros favoráveis para a proliferação desse culicídeo, há oferta de alimento pela presença de animais apreendidos, animais domésticos e pelo próprio homem. Além desses fatores, a possibilidade de abrigos no ambiente domiciliar próximo, facilita a proliferação de Ae. scapularis motivando sua maior abundância. 
A $2^{a}$ posição em abundância de espécies foi igualada por $C x$ quinquefasciatus $($ IAEP $=0,9)$ e $\boldsymbol{C}$. declarator $(\mathbf{I A E P}=0,9)$. Existe no Parque uma série de lagoas e córregos poluidos, que vêm propiciando excelentes criadouros para esses mosquitos, contribuindo para a sua abundância.

Quanto ao Ae. albopictus, espécie alóctone atingiu apenas a $7^{\mathrm{a}}$ posição em abundância de espécies $(\mathbf{I A E P}=0,4)$. A baixa freqüência desse culicídeo na área foi também assinalada por ( URBINATTI e col.,1998). Por sua vez, (GOMES, e col., 1992 ) assinalaram a preferência desse mosquito por área rural no Vale do Paraiba.

Outra espécie que mereceu atenção foi $\boldsymbol{C} \boldsymbol{x}$. chidesteri, apesar de não estar entre as mais abundantes $\left(5^{\mathrm{a}}\right.$ posição) $(\mathbf{I A E P}=0,6)$, esteve presente em todos os ambientes pesquisados. Isto sugere seu processo de adaptação ao ambiente antrópico. 
Tabela 7. Posição por abundância numérica e Indice da Abundância de Espécies dos Culicideos capturados por armadilha luminosa tipo CDC (+ gelo seco) em diferentes ambientes de coleta. Parque Ecológico do Tietê. Guarulhos. Estado de São Paulo. no periodo de 1996 a 1998.

\begin{tabular}{|c|c|c|c|c|c|c|c|c|c|c|c|c|c|c|}
\hline $\begin{array}{l}\text { Categorias } \\
\text { Taxonômicas }\end{array}$ & MAT & PM & $\mathrm{ABE}$ & PA & PER & PP & INT & PI & TOT & $\mathbf{a}$ & $\mathrm{Pj}$ & $\mathrm{IAE}$ & IAEP & $\mathbf{P}$ \\
\hline Ae scapularis & 3800 & 1 & 7578 & 1 & 1421 & 1 & 1693 & 1 & 14492 & 0 & 4 & 1 & 1.0 & $1^{a}$ \\
\hline Cx. quinquefasciatus & 429 & 2 & 1098 & 2 & 571 & 2 & 262 & 2 & 2360 & 0 & 8 & 2 & 0.9 & $2^{a}$ \\
\hline Cx declarator & 337 & 3 & 1057 & 3 & 326 & 3 & 6 & 4 & 1726 & 0 & 13 & 3,2 & 0.9 & $2^{\mathrm{a}}$ \\
\hline$C x$ gr. coronator & 84 & 4 & 289 & 4 & & & & & 373 & 10 & 8 & 4.5 & 0.8 & $3^{2}$ \\
\hline Ma. indubitans & 82 & 6 & 94 & 6 & 16 & 4 & 12 & 3 & 204 & 0 & 19 & 4,7 & 0.8 & $3^{8}$ \\
\hline Cq. venezuelensis & 83 & 5 & 207 & 5 & 2 & 7 & & & 292 & 8 & 17 & 6.2 & 0.7 & $4^{\mathrm{a}}$ \\
\hline Ma. titillans & 55 & 7 & 82 & 7 & 12 & 5 & & & 149 & 8 & 19 & 6,7 & 0.7 & $4^{a}$ \\
\hline An. strodei & 9 & 8 & 43 & 8 & & & & & 52 & 18 & 16 & 8.5 & 0.6 & $5^{\mathrm{a}}$ \\
\hline Cx. chidesteri & 7 & 9 & 11 & 12 & 5 & 6 & 2 & 6 & 25 & 0 & 33 & 8.2 & 0.6 & $5^{\mathrm{a}}$ \\
\hline An. albìarsis & 4 & 12 & 20 & 9 & & & 5 & 5 & 29 & 13 & 26 & 9.7 & 0.5 & $6^{a}$ \\
\hline Ae. albopictus & 2 & 14,5 & 8 & 13 & 1 & 8 & 1 & 7 & 12 & 0 & 42.5 & 10.6 & 0.4 & $7^{\mathrm{a}}$ \\
\hline An . evansae & 6 & 10 & 12 & 11 & & & & & 18 & 24 & 21 & 11,2 & 0.4 & $7^{\mathrm{a}}$ \\
\hline Ps. ferox & 5 & 11 & 13 & 10 & & & & & 18 & 24 & 21 & 11,2 & 0.4 & $7^{\mathrm{a}}$ \\
\hline Cx. (Mel.)gr.pilosus & 1 & 17.5 & 5 & 14 & & & & & 6 & 37 & 31.5 & 17,1 & 0.1 & $8^{2}$ \\
\hline$C x .(M e l)$.$s Melan.$ & 1 & 17.5 & 4 & 15,5 & & & & & 5 & 37 & 33.0 & 17.5 & 0.08 & $9^{a}$ \\
\hline Cx.(Mel) ribeirensis & & & 2 & 16 & & & & & 2 & 51 & 16 & 16,7 & 0.1 & $8^{a}$ \\
\hline Ps. discrucians & & & 4 & 15,5 & & & & & 4 & 49.5 & 15.5 & 16,2 & 0.1 & $8^{a}$ \\
\hline Ae. fluviatilis & 3 & 13 & 1 & 18 & & & & & 4 & 38 & 31 & 17,2 & 0.1 & $8^{a}$ \\
\hline Cx. brethesi & 1 & 17.5 & 1 & 18 & & & & & 2 & 38 & 35.5 & 18.3 & 0.04 & $11^{\mathrm{a}}$ \\
\hline Ps. ciliata & & & 2 & 16 & & & & & 2 & 51 & 16 & 16.7 & 0.1 & $8^{2}$ \\
\hline Cx. bidens & 1 & 17.5 & 1 & 18 & & & & & 2 & 38 & 35.5 & 18.3 & 0.03 & $12^{\mathrm{a}}$ \\
\hline Cx. mollis & 1 & 17.5 & & & & & & & 1 & 55,5 & 17.5 & 18,1 & 0.05 & $10^{\mathrm{a}}$ \\
\hline Ur. lowii & 1 & 17.5 & & & & & & & 1 & 55,5 & 17.5 & 18,1 & 0.05 & $10^{\mathrm{a}}$ \\
\hline Cx. nigripalpus & 2 & 14.5 & 2 & 16 & & & & & 4 & 34 & 30.5 & 16,1 & 0.1 & $8^{a}$ \\
\hline
\end{tabular}

MAT - mata: PM - posição na mata: ABER - aberto; PA - posição no aberto: PERI peridomicílio: PP - posição no peridomicílio: INTRA - intradomicílio: PI - posição no intradomicilio; TOT - total: a - número de células brancas x c (posição mais alta + 1); PJ - soma das posições; IAE - Indice de Abundância de Espécies: IAEP - Índice de Abundância de Especies Padronizado: P - Posição por abundância numérica. 
$\mathrm{O}$ índice de abundância pode ser um indicador de risco ambiental e epidemiológico. Além disso, pode fornecer dados de tendências sazonais, dinâmica de transmissão ou avaliação das intervenções de controle de uma população vetora. Nesse contexto, Ae. scapularis tem competência vetorial para vários arbovírus e outros agravos à saúde, sua abundância pode ser um indicador de risco na transmissão de arbovirose e outras parasitoses.

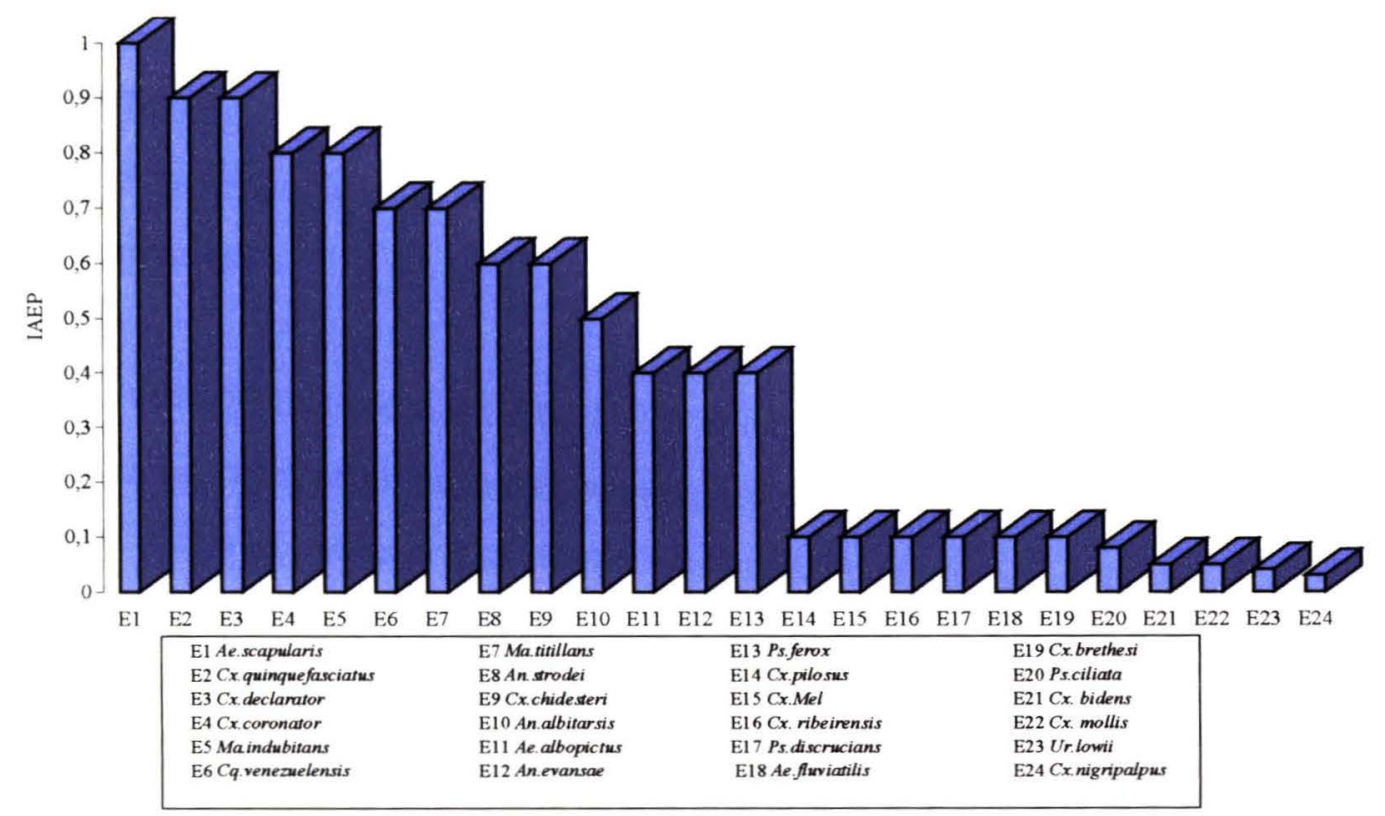

Figura 26. Índice de Abundância de Espécies Padronizado de culicideos coletados com armadilha tipo CDC ( + gelo seco) no Parque Ecológico do Tietê, Guarulhos, São Paulo, 1996 -1998

\subsection{Diversidade e Dominância de culicídeos.}

Para estimar a diversidade das espécies no Parque, utilizou-se do Índice (IDv) segundo Margalef (citado por Service,1993). Esse índice, quando estimado para toda a população de culicídeos do Parque atingiu o nível de 2,2. Na mata residual foi de 2,3; na vegetação aberta atingiu 2,1 e no ambiente domiciliar 1,3 . Nota-se que esse índice diminui da mata em direção ao ambiente antrópico.

Foi estimado o Quociente de similaridade (QS) conforme descrito na metodologia. Esse quociente quando calculado comparando a mata e aberto, atingiu $\mathbf{Q S}=0,9$. No Parque Ecológico, a área de vegetação aberta é uma pequena faixa muito próxima à mata residual, motivando a similaridade da composição de espécies em 
ambos os locais. Há também uma contiguidade do ambiente aberto em relação ao ambiente domiciliar, sendo que o quociente de similaridade entre esses ambientes atingiu $\mathbf{Q S}=0,8$.

FORATTINI e col, em 1986, assinalaram que a fauna de culicídeos de áreas submetidas a alterações ambientais, pode sofrer impactos em conseqüência da destruição de seus ecótopos e da incapacidade de adaptação de determinadas espécies às condições surgidas. Ao mesmo tempo, outras espécies adaptam-se às áreas alteradas, proliferando-se intensamente, podendo causar incômodo ou transmitir doenças. No Parque Ecológico, tem-se registrado que essas modificações favoreceram a adaptação de varias espécies de culicideos, principalmente a proliferação de Ae. scapularis e $C x$. quinquefasciatus

FORATTINI e col. $(1986,1995)$ assinalaram que a atividade antrópica, induz a alterações no comportamento das populações primitivas. Esses autores, registraram Ae. serratus, Ae. scapularis e $\boldsymbol{C}$. ribeirensis predominando no ambiente modificado para desenvolvimento de atividades agrícolas. Concordando com essa observação, no Parque Ecológico do Tietê, Ae. scapularis foi espécie presente nos diversos habitats predominando em ambiente modificado, sugerindo seu potencial de adaptação.

Para estimar a dominância de espécies no Parque Ecológico, relativo ao periodo pesquisado, foi calculado o do Indice (IDo) conforme Barber-Parker (citado por Service, 1993). Dessa maneira, foi conferida a dominância ao Ae. scapularis (ID $=59 \%$ ) e $C x$ quinquefasciatus $(\mathrm{ID}=27 \%)$. Por sua vez, $\boldsymbol{C x}$. declarator atingiu apenas $(\mathrm{ID}=$ $8 \%$ ).

Nesse trabalho, o indice de diversidade mostrou ser um bom indicador da composição faunística de culicídeos no Parque e de sua distribuição espacial. Salientase considera-lo como um bom indicador ambiental de vigilância e monitoramento

Por sua vez, o indice de dominância, pode ser um bom indicador da adaptação das espécies ao ambiente alterado. Nesse estudo, Ae scapularis foi espécie dominante em ambiente aberto sugerindo o processo de adaptação desse mosquito ao ambiente antrópico. Cx. quinquefasciatus destacou-se por sua dominância em ambiente 
domiciliar, espécie reconhecida por sua eusinantropia. Ressalta-se a importância da utilidade desse índice em estudos de monitoramento e vigilância entomológica.

\subsection{Distribuição mensal das espécies mais abundantes.}

Quanto à atividade mensal dos culicídeos mais abundantes, calculou-se a média de Williams (Xw) para expressar à atividade mensal, segundo a técnica utilizada no periodo pesquisado. Dados de pluviosidade e temperatura do ar (médias mensais) foram obtidos para esse periodo

FORATTINI, em 1992, assinalara que as mudanças de tamanho das populações de culicídeos de acordo com o suceder das estações do ano são normalmente controladas por fatores ambientais que variam em igual ritmo. Esses fatores extrinsecos são decorrentes de condições climáticas.

CABRAL, em 1997, assinalara que as ações antropogênicas são responsáveis diretas pelas alterações do ambiente local e particularmente, do clima urbano. Tais ações refletem-se no balanço energético entre a superficie local e a atmosfera, conjugada à intensa impermeabilização do solo, à diminuição das áreas verdes, ao crescente adensamento das edificações, além do calor gerado pela dinâmica urbana; produzindo derivações significativas na evolução da temperatura, da precipitação pluviométrica, da umidade do ar, da direção e da velocidade dos ventos entre outros (CABRAL e JESUS, 1994)

Segundo CABRAL, em 1997, os elementos climáticos, principalmente a temperatura e a umidade relativa do ar, têm vinculações em vários graus com o processo de evolução urbana e que, paralelamente, existem diferentes configurações microclimáticas presentes na cidade de São Paulo. Esse autor, assinala ainda que, em nivel espacial nos anos recentes, registraram os maiores valores pluviométricos, principalmente em direção ao norte do município.

No Parque Ecológico do Tietê, observou-se que quando a pluviosidade e a temperatura do ar foram maiores, a quantidade de mosquitos acompanhou geralmente esse ritmo e viceversa. No periodo pesquisado, houve uma tendência geral de aumento 
de chuva, além da variabilidade temporal das mesmas e a alteração de sua sazonalidade, fatos esses possivelmente relacionados aos eventos interanuais do fenômeno "El Niño", sendo detectados os efeitos a partir de setembro de 1997, quando as chuvas situaram-se acima da média sobre o sul do país. No mês de janeiro de 1998, as temperaturas registradas foram acima do normal climatológico. Conseqüêntemente, registrou-se um aumento expressivo da atividade de culicídeos, nos meses de fevereiro e março desse ano.

A irregularidade na frequêencia de Aescapularis ao longo do ano, foi assinalada por FORATTINI e col., 1978. Por sua vez, vários autores GUIMARÃES e ARLÉ, 1984; LOURENÇO DE OLIVEIRA e col., 1984; FORATTINI e GOMES, 1988; TEODORO e col., 1994, 1995, observaram que a atividade de Ae. scapularis aumenta logo após o início das chuvas, seguido de rápido declínio mesmo na estação quente e chuvosa. Esses autores sugeriram que os períodos de chuva e de seca, parecem controlar a atividade dessa espécie.

LOURENÇO DE OLIVEIRA e col., em 1985 assinalaram picos altos de atividade para Ae scapularis a partir de agosto a janeiro em área de planície no Rio de Janeiro. No mesmo Estado, porém uma área montanera, GUIMARÃES e ARLÉ (1984) registraram a atividade desse mosquito, durante os meses de janeiro a dezembro, desaparecendo quase por completo nos meses de inverno. Já TEODORO e col., 1995, no Estado do Paraná, encontraram o mesmo mosquito ativo ao longo do ano, sendo freqüente nos meses de março e junho, porém com maior atividade em fevereiro.

Por sua vez, MENEZES, (1997) em estudos realizados em áreas de influência de Hidrelétricas no Paranapanema, observou sincronismo entre a maior atividade mensal de Ae. scapularis e os períodos de chuva e de seca. Já BRUNO (1997), quando pesquisou em ambiente de transição, no Vale do Ribeira, registrou a presença de $\boldsymbol{A} \boldsymbol{e}$. scapularis ao longo do ano e assinalou a discrepância na atividade desse mosquito nos meses de maio, novembro e março, quando procurou relacionar esses dados com a distribuição das chuvas.

Nesse trabalho, Ae. scapularis esteve presente ao longo de todo ano, com exceção dos meses de agosto e setembro, em que fora registrado declinio na atividade 
desse mosquito. Essa observação foi constatada nos dois anos consecutivos; o que sugere o controle da população dessa espécie. Registraram-se picos de atividade a partir de outubro ao março, sendo os maiores nos meses de novembro e dezembro. Como resultado das altas temperaturas e intensas chuvas provocadas pelo fenômeno "El Niño", nos meses de fevereiro e março de 1998, houve no Parque extensas áreas temporariamente alagadas, criadouros desse mosquito, o que explica o aumento da população nesse período (Xw= 65,8\%) ( Fig 27 ).

Conforme o cálculo do coeficiente de correlação de Pearson, o coeficiente de correlação entre a atividade mensal de $A$ e. scapularis e a pluviosidade média mensal é igual a $(\mathbf{r}=0,22)(\mathbf{p}=0,335)$. Quanto à temperatura média mensal e atividade desse mosquito, o coeficiente de correlação foi igual a $(\mathbf{r}=0,3892)(\mathbf{p}=0,090)$ o qual indica que existe correlação baixa entre esses parâmetros ambientais e a atividade desse culicídeo (Anexo 6).

Por sua vez, Cx. quinquefasciatus se mostrou ativo ao longo do ano, .registrando picos de atividade a partir de setembro e atingindo abril. Observou-se que a distribuição mensal não acompanhou exatamente a distribuição das chuvas. Coincidindo com os efeitos do fenômeno "EL Niño", registrou-se uma maior atividade desse culicídeo nos meses de fevereiro e março, o que explicaria picos de atividade nesse período ( Fig 28).

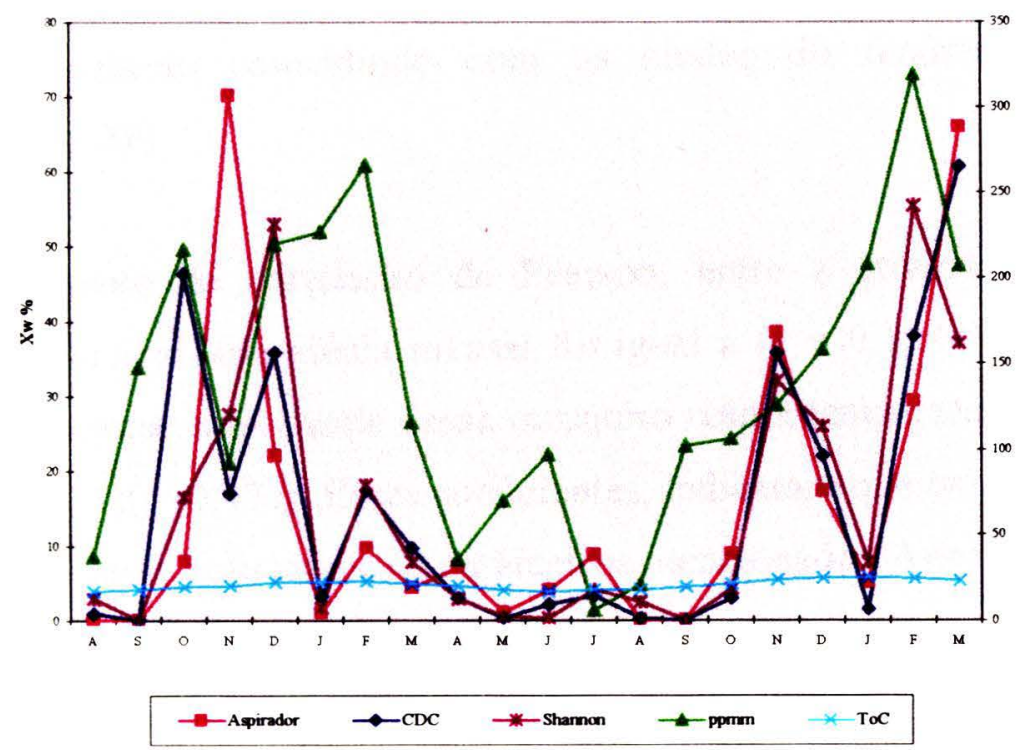

Figura 27. Atividade mensal de Ae scapularis segundo a pluviosidade,temperatura e técnica de coleta no Parque Ecológico do Tietê, Guarulhos, São Paulo. 1996-1998. 
O cálculo do coeficiente de correlação de Paerson para a atividade mensal de Cx. quinquefasciatus e a pluviosidade média mensal foi igual a $(\mathbf{r}=0,3867)(\mathbf{p}=0,092)$. Quanto à temperatura média mensal esse coeficiente foi igual a $(\mathbf{r}=0,3559)(\mathbf{p}=0,124) \mathrm{o}$ qual indica que existe correlação baixa entre a atividade desse mosquito e os parâmetros mencionados (Anexo 7).

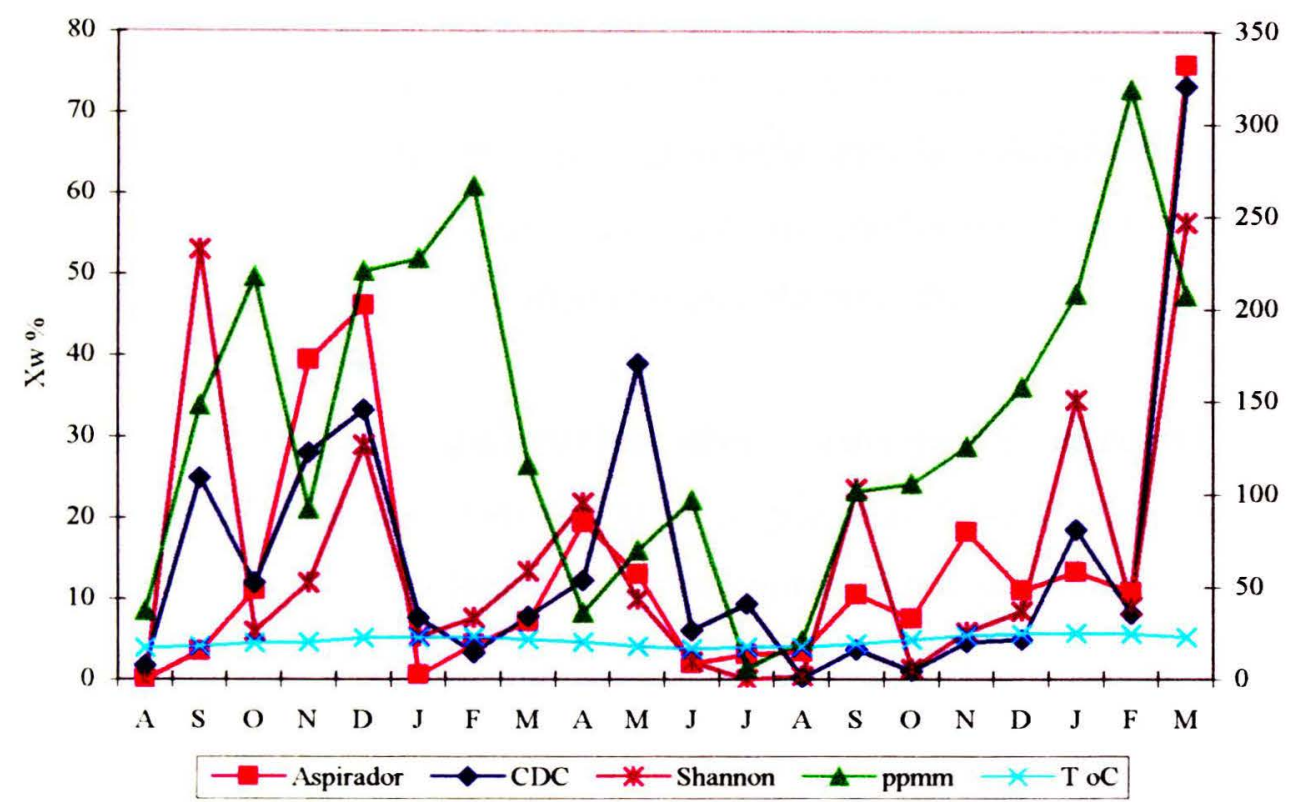

Figura 28. Atividade mensal de $C x$. quinquefasciatus segundo pluviosidade, temperatura e técnica de coleta no Parque Ecológico do Tietê, Guarulhos. São Paulo, 1996 - 1998.

Cx. declarator mostrou-se ativo ao longo do ano e sua freqüência registrou queda nos meses de junho e julho. A distribuição mensal não acompanhou exatamente a distribuição de chuvas na área. Da mesma forma que as anteriores espécies, registrou-se aumento da população coincidindo com os efeitos do fenômeno "El Niño" já mencionados. (Fig 29)

O coeficiente de correlação de Pearson, entre a atividade mensal de $\boldsymbol{C} \boldsymbol{x}$. declarator e a pluviosidade média mensal foi igual a $(\mathbf{r}=0,1244)(\mathbf{p}=0,601)$. Quando tentou-se correlacionar a atividade desse mosquito com a temperatura, o coeficiente foi igual a $(\mathbf{r}=0,1711)(p=0,471)$. Esses coeficientes, indicaram que existe correlação baixa entre a atividade desse culicídeo e os parâmetros mencionados(Anexo 8).

Embora estatisticamente a correlação entre a atividade desses culicídeos e os regimes de precipitação e temperatura seja baixa, considerando a biologia e ecologia 
desses mosquitos, esses parâmetros agem direta ou indiretamente na sua atividade. Dessa maneira, Ae. scapularis é espécie de criadouros temporários e ensolarados, onde as fềmeas ovipõem de preferência em depressões no solo, com potencial de serem inundados com as chuvas. Esses ovos são resistentes à dissecação e entram em diapausa na época de estiagem ou seca, podendo-se acumular uma grande quantidade de ovos nesses criadouros em potencial. Por ação das chuvas, essas depressões de solo são inundadas, facilitando a eclosão dos ovos simultaneamente, quando então a espécie torna-se abundante. Nesse sentido, sua atividade estaria relacionada também às condições favoráveis para a formação e expansão de criadouros, que no caso do local estudado esta representado por áreas abertas com solo propício.

Por sua vez, $\boldsymbol{C}$. quinquefasciatus, usualmente precisa para seu desenvolvimento de criadouros com alto grau de poluição. Esse culicídeo desenvolvese nas margens do Rio Tietê, colonizadas principalmente por gramíneas. O período de pesadas chuvas na estação de verão pode não ser favorável para esse culicídeo, porque grande parte do criadouro pode ser arrastado pela turbulência das águas. Entretanto, no período mais seco, as águas estagnadas favorecem a proliferação da espécie. Nas proximidades do Parque Ecológico, existem também córregos poluídos, criadouros desse mosquito, Havendo elevação da temperatura sua atividade é aumentada, registrando-se aumento da população. Nesse estudo, foi espécie abundante, causando incômodo `as comunidades anexas..

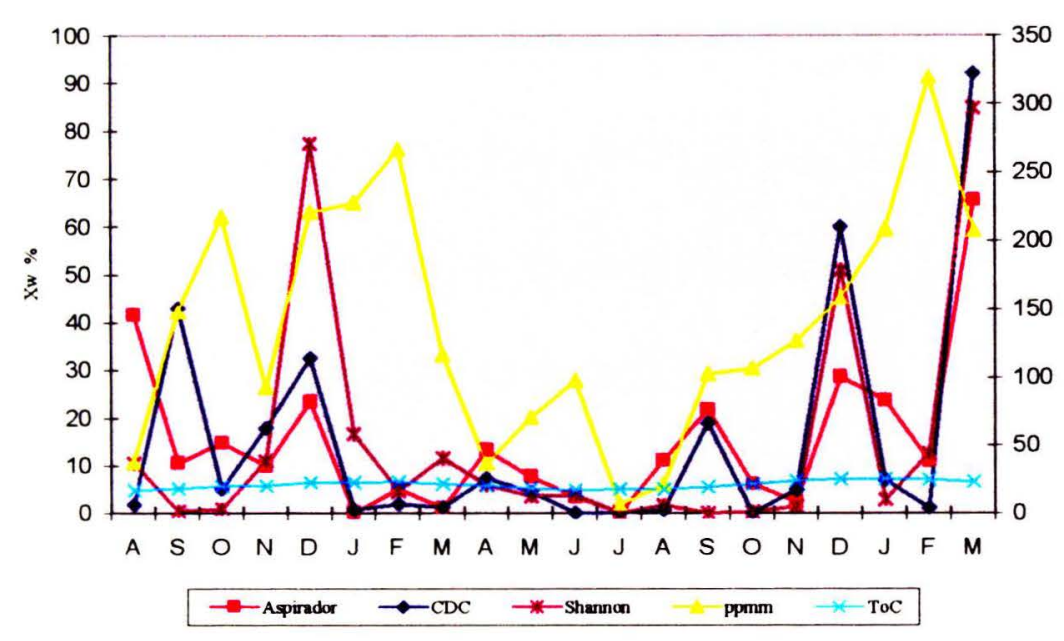

Figura 29. Atividade mensal de $C \boldsymbol{x}$ declarator segundo a pluviosidade, temperatura e técnica de coleta no Parque Ecológico do Tietê. Guarulhos, São Paulo, 1996 - 1998. 


\subsection{Freqüência de culicideos no ambiente peridomiciliar}

Para avaliar a freqüência de culicídeos no ambiente peridomiciliar, realizaram-se um total de quatro coletas distribuidas em cada uma das estações do ano. Cada coleta teve uma duração de 24 horas ininterruptas em ambiente peridomiciliar com atrativo luminoso, humano e aspirador elétrico. Essas coletas, forneceram um total de 1998 espécimens de culicídeos, representado por 12 espécies (Tabela 8).

Registrou-se, assim, que Cx. quinquefasciatus $(54,6 \%)$ foi espécie predominante e , na estação de inverno, apenas esse mosquito compareceu às coletas Por sua vez, Aedes scapularis (34,7\%) despontou em segundo lugar nesse ambiente. Quanto a Culex declarator $(3,7 \%)$ esteve presente apenas na estação de outono. Registrou-se, alem destas a presença de representantes de espécies de importância epidemiológica, entre elas: An. albitarsis, $A \boldsymbol{n}$. strodei, Ma. titillans, Ma. indubitans e Ae. albopictus. Embora menos freqüente, foi também registrada a presença de $C x$. chidesteri e $C x$.ribeirensis. Esse registro concorda com as observações relatadas por (FORATTINI e col., 1986, 1987, 1989; GOMES e FORATTINI, 1990).

A frequência elevada de Aedes scapularis coletada em isca humana e em ambientes degradados tem confirmado a antropofilia e a possivel adaptação desse culicídeo nesses ambientes, salientando-se também seu possivel papel na transmissão da Encefalite e outras arboviroses (FORATTINI e col.,1978, 1978a, 1981, 1987, 1987a, 1990, 1995; LOURENÇO DE OLIVEIRA 1984; LOURENÇO DE OLIVEIRA \& HEYDEN 1986; MARQUES 1994; ROBERTS e col., 1985). 
Tabela 8. Frequència peridomiciliar de culicideos distribuidos sazonalmente. coletados com isca humana durante 24 horas no Parque Ecológico do Tietê. Guarulhos. São Paulo. 1997 a 1998.

\begin{tabular}{|c|c|c|c|c|c|c|c|c|c|c|}
\hline \multirow{2}{*}{ Espécie } & \multicolumn{2}{|c|}{ Verão } & \multicolumn{2}{|c|}{ Outono } & \multicolumn{2}{|c|}{ Inverno } & \multicolumn{2}{|c|}{ Primavera } & \multirow{2}{*}{ No } & \multirow{2}{*}{$\%$} \\
\hline & No & $\%$ & No & $\%$ & No & $\%$ & $\mathrm{~N}$ & $\%$ & & \\
\hline Cx. quinquefasciatus & 634 & 50.2 & 321 & 55,4 & 58 & 100.0 & 78 & 80.4 & 1091 & 54.6 \\
\hline Ae. scapularis & 569 & 45.0 & 107 & 18,4 & 0 & 0,0 & 17 & 17.6 & 693 & 34,7 \\
\hline Cx declarator & 0 & 0.0 & 73 & 12.7 & 0 & 0,0 & 0 & 0.0 & 73 & 3,7 \\
\hline Ma indubitans & 30 & 2.3 & 21 & 3.7 & 0 & 0,0 & 0 & 0.0 & 51 & 2,6 \\
\hline Ma. tutillans & 18 & 1.4 & 11 & 2,0 & 0 & 0.0 & 0 & 0.0 & 29 & 1.5 \\
\hline An. strodei & 0 & 0.0 & 26 & 4.5 & 0 & 0.0 & 0 & 0.0 & 26 & 1,3 \\
\hline An. albitarsis & 6 & 0.5 & 16 & 2.8 & 0 & 0,0 & 0 & 0.0 & 22 & 1.1 \\
\hline Ae. albopictus & 6 & 0.5 & 2 & 0,3 & 0 & 0.0 & 0 & 0.0 & 8 & 0.4 \\
\hline Cq. venezuelensis & 1 & 0.1 & 1 & 0.1 & 0 & 0.0 & 0 & 0.0 & 2 & 0.1 \\
\hline$C x \cdot g r$ coronator & 0 & 0.0 & 0 & 0.0 & 0 & 0.0 & 1 & 1.0 & 1 & 0.0 \\
\hline Cx chidesteri & 0 & 0.0 & 0 & 0.0 & 0 & 0.0 & 1 & 1.0 & 1 & 0.0 \\
\hline$C x$ (Mel.) ribeirensis & 0 & 0.0 & 1 & 0.1 & 0 & 0.0 & 0 & 0.0 & 1 & 0.0 \\
\hline Total & 1264 & 100.0 & 579 & 100.0 & 58 & 100.0 & 97 & 100.0 & 1998 & 100.0 \\
\hline
\end{tabular}

\subsection{Atividade horária de culicídeos mais freqüentes no ambiente peridomiciliar.}

Quanto à atividade horária de Ae. scapularis, diversos autores assinalaram padrões de comportamento para esse culicideo. Assim sendo, nesse trabalho, a mencionada espécie revelou o maior pico de atividade durante o crepúsculo vespertino $(\mathbf{X w}=36,2 \%)$, no início da noite $(\mathbf{X w}=15 \%)$ e em horário matutino $(\mathbf{X w}=19,5 \%)$. Das 10 horas às 17 horas não foi registrada atividade desse mosquito nesse ambiente. Esses resultados são semelhantes aos obtidos em diversos Estados como: São Paulo, Rio de Janeiro e Parana por FORATTINI e col, (1981, 1987a); LOURENÇO DE OLIVEIRA \& SILVA (1985) GUIMARÃES \& VICTÓRIO (1986) FORATTINI \& GOMES (1988) TEODORO e col.,(1994, 1995) MENEZES (1997) BRUNO (1997). O período de atividade desse culicideo, resume-se na Tabela 9, Fig 30. 
Tabela 9. Atividade horária de Aedes scapularis coletado com isca humana. durante 24 horas em diversas estações do ano. no Parque Ecológico do Tietê. Guarulhos. São Paulo, 1998.

\begin{tabular}{|c|c|c|c|c|c|c|c|}
\hline Horário & Verão & Outono & Inverno & Primavera & IPHH & $\mathrm{Xw}$ & $\mathrm{Xw} \%$ \\
\hline 17-18hrs & 0 & 85 & 0 & 0 & 10.6 & 1.5 & 7.0 \\
\hline 18-19hrs & 65 & 7 & 0 & 0 & 9 & 3 & 13.6 \\
\hline 19-20hrs & 248 & 4 & 0 & 9 & 32,6 & 8 & 36.2 \\
\hline $20-21 \mathrm{hrs}$ & 181 & 3 & 0 & 0 & 23 & 3.3 & 15.0 \\
\hline 21-22hrs & 8 & 1 & 0 & 0 & 1,1 & 0.7 & 3.2 \\
\hline $22-23 \mathrm{hrs}$ & 2 & 0 & 0 & 0 & 0,25 & 0,1 & 0.4 \\
\hline 23-24hrs & 3 & 0 & 0 & 0 & 0.37 & 0.1 & 0.4 \\
\hline $24-0$ lhrs & 1 & 0 & 0 & 0 & 0.12 & 0 & 0.0 \\
\hline $01-02 \mathrm{hrs}$ & 12 & 0 & 0 & 0 & 1,5 & 0.6 & 2.7 \\
\hline $02-03$ hrs & 0 & 0 & 0 & 1 & 0.12 & 0 & 0.0 \\
\hline $03-04$ hrs & 2 & 0 & 0 & 0 & 0.25 & 0.1 & 0.4 \\
\hline $04-05 \mathrm{hrs}$ & 2 & 0 & 0 & 0 & 0.25 & 0.1 & 0.4 \\
\hline $05-06 \mathrm{hrs}$ & 0 & 0 & 0 & 2 & 0.25 & 0.1 & 0.4 \\
\hline $06-07$ hrs & 33 & 7 & 0 & 5 & 5,6 & 4.3 & 19.5 \\
\hline $07-08 \mathrm{hrs}$ & 2 & 0 & 0 & 0 & 0.25 & 0.1 & 0.4 \\
\hline 08-09hrs & 1 & 0 & 0 & 0 & 0.12 & 0 & 0.0 \\
\hline 09-10hrs & 2 & 0 & 0 & 0 & 0.25 & 0.1 & 0.4 \\
\hline $10-11 \mathrm{hrs}$ & 0 & 0 & 0 & 0 & 0.0 & 0 & 0.0 \\
\hline
\end{tabular}

IPHH = Indice de picada/homem/hora

$\mathbf{X w}=$ Média de Williams

Obs: Das 11 às 17 horas as coletas foram negativas.

Por sua vez, Culex quinquefasciatus mostrou-se ativo nos diversos horários apartir do crepúsculo vespertino ate o horário matutino ( 6 horas), capturando-se-o porém ao longo da noite. Apresentou picos de maior atividade a partir das $23 \mathrm{hrs}$, atingindo sua maior atividade das 03 às 04 horas $(\mathbf{X w}=22,4 \%)$. Essas observações são concordantes com as assinaladas por diversos autores como FORATTINI e col., (1978; 1986, 1987); LOURENÇO DE OLIVEIRA e HEYDEN (1986); NATAL e col., (1991). Nota-se que no período claro do dia (das 07 às 17 horas) não foi coletado nenhum exemplar da espécie considerada. As horas de atividade estão resumidas na Tabela 13 e Fig 30. 
Tabela 10. Atividade horária de Culex quinquefasciatus coletado com isca humana. durante 24 horas em diversas estações do ano no Parque Ecológico do Tietê. Guarulhos. São Paulo. 1998.

\begin{tabular}{|c|c|c|c|c|c|c|c|}
\hline Horário & Verão & Outono & Inverno & Primavera & IPHH & Xw & Xw\% \\
\hline $17-18 \mathrm{hrs}$ & 0 & 26 & 0 & 0 & 3,25 & 0.9 & 1,0 \\
\hline $18-19 \mathrm{hrs}$ & 200 & 4 & 2 & 0 & 25.7 & 5.2 & 6.0 \\
\hline $19-20 \mathrm{hrs}$ & 32 & 4 & 9 & 1 & 5,7 & 5.3 & 6.0 \\
\hline $20-2$ lhrs & 20 & 3 & 5 & 1 & 3,6 & 3.7 & 4.1 \\
\hline $21-22 \mathrm{hrs}$ & 0 & 5 & 4 & 0 & 1.1 & 0.9 & 1.0 \\
\hline $22-23 \mathrm{hrs}$ & 0 & 11 & 3 & 3 & 2.1 & 2.1 & 2,4 \\
\hline $23-24 \mathrm{hrs}$ & 1 & 55 & 7 & 9 & 9.0 & 7.1 & 8.0 \\
\hline $24-01 \mathrm{hrs}$ & 0 & 94 & 5 & 23 & 15.2 & 8.0 & 9,0 \\
\hline $01-02 \mathrm{hrs}$ & 11 & 47 & 10 & 15 & 10.3 & 14 & 16.0 \\
\hline $02-03 \mathrm{hrs}$ & 127 & 46 & 1 & 14 & 23.5 & 16.2 & 18.4 \\
\hline $03-04 \mathrm{hrs}$ & 161 & 26 & 6 & 11 & 25.5 & 19.7 & 22,4 \\
\hline $04-05 \mathrm{hrs}$ & 57 & 6 & 0 & 1 & 8.0 & 3.4 & 4.0 \\
\hline $05-06 \mathrm{hrs}$ & 17 & 3 & 0 & 0 & 2,5 & 1.4 & 1.5 \\
\hline $06-07 \mathrm{hrs}$ & 4 & 0 & 0 & 0 & 0.5 & 0.2 & 0.2 \\
\hline
\end{tabular}

IPHH= Indice de picada/homem/hora.

$\mathrm{X} w=$ Média de Williams.

Obs: Das 07 às 17 horas as coletas foram negativas.

Culex declarator revelou baixa atividade no ambiente peridomiciliar, atingindo o maior pico no horário crepuscular vespertino $(X \mathbf{w}=42,3 \%)$. Sua presença limitou-se à estação de outono. No periodo das 07 às 17 horas não foi registrada à atividade desse mosquito ao longo das coletas (Tabela 11, Fig 30).

Pesquisadores como LOURENÇO DE OLIVEIRA E HEYDEN (1986) e FORATTINI e col., (1989) assinalaram hábito preferentemente ornitofilico de Culex declarator. No Parque, existe uma fauna rica em aves. Essa fauna, provavelmente atrai esse mosquito fora dos limites do peridomicílio, o que pode explicar sua baixa frequêencia nesse ambiente 
Tabela 11. Atividade horária de Culex declarator coletado com isca humana, durante 24 horas em diversas estações do ano no Parque Ecológico do Tietê, Guarulhos, São Paulo, 1998.

\begin{tabular}{|l|c|c|c|c|c|l|l|}
\hline Horário & Verão & Outono & Inverno & Primavera & IPHH & Xw & Xw \% \\
\hline $17-18 \mathrm{hrs}$ & 0 & 39 & 0 & 0 & 4,8 & 1,1 & 42,3 \\
\hline $18-19 \mathrm{hrs}$ & 0 & 15 & 0 & 0 & 1,8 & 0,6 & 23,0 \\
\hline $19-20 \mathrm{hrs}$ & 0 & 4 & 0 & 0 & 0,5 & 0,2 & 8,0 \\
\hline $20-2$ lhrs & 0 & 2 & 0 & 0 & 0,25 & 0,1 & 3,8 \\
\hline $21-22 \mathrm{hrs}$ & 0 & 1 & 0 & 0 & 0,12 & 0 & 0,0 \\
\hline $22-23 \mathrm{hrs}$ & 0 & 8 & 0 & 0 & 1,0 & 0,4 & 15,3 \\
\hline $23-24 \mathrm{hrs}$ & 0 & 2 & 0 & 0 & 0,25 & 0,1 & 3,8 \\
\hline $05-06 \mathrm{hrs}$ & 0 & 2 & 0 & 0 & 0,25 & 0,1 & 3,8 \\
\hline
\end{tabular}

IPHH= Índice de Picada/homem/hora.

$\mathbf{X} \mathbf{w}=$ Média de Williams

Obs: Das 24 às 05horas; das 06 às 17 horas as coletas foram negativas.

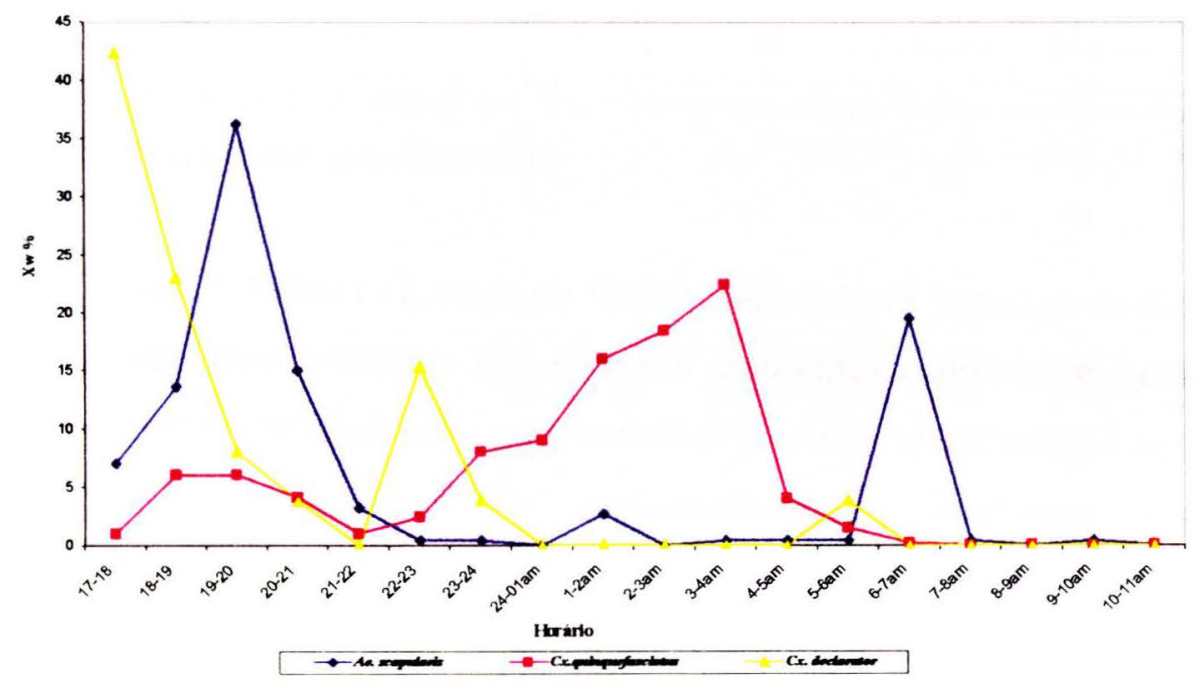

Fgura 30. Atividade horaria de culicteos mais frequentes no Parque Ecologico do Tieế, Guarulhos, Săo Paulo. 1996 - 1998

\subsection{Detecção de sangue de primatas.}

$\mathrm{O}$ antisoro humano usado no teste de precipitina não reconheçe especificamente inmunoglobulinas humanas pois, as reações cruzam-se com as de primata, fato esse que impossibilita a definição exata do repasto sangüíneo.

No tocante ao teste de detecção de sangue ingerido, um total de 830 espécimes ingurgitadas, representando sete espécies, foram selecionados para o teste de 
precipitina. Esses mosquitos procederam das coletas com armadilhas CDCs nos diversos habitats pesquisados. Desses, $54 \%$ foram positivos para sangue de primatas, sendo $19 \%$ coletados na mata, $56 \%$ na vegetação aberta, $17,4 \%$ no peridomicilio e $8 \%$ no intradomicilio (Tabela 12).

Tabela 12. Resultado do Teste de Precipitina para sangue de primatas. em culicídeos ingurgitados colctados com armadilhas CDCs (+ gelo seco). segundo a técnica de tubo capilar. Parque Ecológico do Tictê. Guarulhos. São Paulo. 1998.

\begin{tabular}{|l|c|c|c|c|c|c|c|c|c|c|}
\hline Espécie & Testados & Posit & Mata & Posit & Aberto & Posit & Peri & Posit & Intra & Posit \\
\hline Ae. scapularis & 250 & 136 & 65 & 34 & 163 & 88 & 10 & $8(80 \%)$ & 12 & $6(50 \%)$ \\
\hline Cx. quinquefasciatus & 250 & 182 & 33 & 17 & 121 & 81 & 63 & $56(89 \%)$ & 33 & $28(85 \%)$ \\
\hline Cx. declarator & 250 & 75 & 52 & $18(34,6 \%)$ & $150(50 \%)$ & 46 & 32 & $10(31,2 \%)$ & 16 & $1(6.2)$ \\
\hline Cx. gr.coronator & 20 & 5 & 4 & 0 & 16 & $5\left(31.2^{\circ} \%\right.$ & 0 & 0 & 0 & 0 \\
\hline Cx. chidesteri & 20 & 17 & 9 & 7 & 6 & $6(100.0)$ & 4 & 3 & 1 & $1(100.0 \%)$ \\
\hline Ma. indubitans & 20 & 14 & 5 & 2 & 15 & 12 & 0 & 0 & 0 & 0 \\
\hline Ma. titillans & 20 & $19(95 \%)$ & 7 & 7 & 12 & 11 & 1 & 1 & 0 & 0 \\
\hline Total (\%) & 830 & $448(54 \%)$ & 175 & $85(19 \%)$ & 483 & $249(56 \%)$ & 110 & $78(17,4 \%)$ & 62 & $36(8 \%)$ \\
\hline
\end{tabular}

Posit $=$ Positivos para o teste de precipitina: Peri $=$ Mosquitos capturados no peridomicílio: Intra= Mosquitos capturados no intradomicilio.

Conforme a Tabela 12, mais de 50\% dos espécimes testados de Ae. scapularis e Cx. quinquefasciatus coletados nos diversos ambientes registraram positividade para sangue de primatas. No ambiente peridomiciliar a positividade atingiu ao $80 \%$ e $89 \%$ Em ambiente intradomiciliar Cx. quinquefasciatus despontou com $85 \%$ de positividade, seguida por Ae. scapularis que atingiu 50\%. Esse resultado pode ser atribuido ao sangue humano. Revelou-se também a positividade para sangue de primatas em espécimes de $\boldsymbol{C} x$. declarator coletados na mata $(34,6 \%)$, no aberto $(30,6)$, em peridomicilio $(31,2 \%)$ e em ambiente intradomiciliar apenas $6,2 \%$ dos espécimes testados foram positivos.

Salienta-se a positividade de $\boldsymbol{C} \boldsymbol{x}$. chidesteri para sangue de primatas em $85 \%$ de espécimes testados e coletados em diversos ambientes. Espécimes coletados em ambientes aberto e intradomiciliar revelaram $100 \%$ de positividade. Esse resultado, evidencia o hábito antropofilico desse culicídeo. Ma titillans coletada nos diversos ambientes, revelou positividade em $95 \%$ dos espécimes testados. Espécimes testados de 
Ma. indubitans revelaram também positividade para sangue de primatas. Em adição, representantes de $\boldsymbol{C x}(\boldsymbol{C u x})$ gr.coronator coletados em ambiente aberto revelaram positividade $(31,2 \%)$ para sangue de primatas.

Nesse trabalho, todas as espécies testadas revelaram positividade para sangue de primatas. Existem no Parque populações de macacos que andam dispersos na mata e no ambiente aberto. Além de aqueles que permanecem em cativeiro no Centro de Triagem até serem realocados em seu lugar de origem. Salienta-se que esse Centro localiza-se próximo à mata. A presença do homem nesses ambientes é continua, ofertando também alimento para esses mosquitos. A positividade para sangue de primatas dos espécimes coletados nesses ambientes pode explicar esse resultado. Espécimes coletados em ambiente domiciliar que revelaram positividade ao teste, permitiu verificar à antropofilia de $\boldsymbol{C} \boldsymbol{x}$ quinquefasciatus e revelar esse hábito em Ae. scapularis, $\boldsymbol{C} \boldsymbol{x}$. chidesteri, Ma. titillans e $\mathbf{C}$. declarator reforçando dessa maneira a adaptação desses culicideos ao ambiente antrópico.

Calculou-se o Índice de Positividade Para o Sangue de Primatas (IPSP) (Tabela 13), sendo que os maiores indices foram registrados por $\boldsymbol{C x}$. quinquefasciatus (IPSP= $72 \%)$, Cx chidesteri $($ IPSP $=65 \%)$, Ae. scapularis $($ IPSP $=54 \%)$ e Ma. titillans $($ IPSP $=$ $45 \%$ ). Esse resultado é indicativo da afinidade desses mosquitos por sangue de primatas e /ou por sangue de humanos

A antropofilia de Ac. scapularis, foi assinalada por diversos pesquisadores como: FORATTINI e col. 1986, 1987, 1987 a, 1987 b, 1989, 1993, 1995; LABARTHE e col., 1998; TEODORO e col., 1994 ; MARQUES 1994. Esses registros são concordantes com os resultados obtidos nesse trabalho, reforçando as evidencias de adaptação desse culicídeo 
Tabela 13. Culicídeos segundo Índice de Positividade para o sangue de primatas. Parque Ecológico do Tietê. Guarulhos. São Paulo. 1998.

\begin{tabular}{|c|c|c|}
\hline ESPECIE & IPSP & $\%$ \\
\hline Cx. quinquefasciatus & 0,72 & 72 \\
\hline Cx. chidesteri & 0.65 & 65 \\
\hline Ae. scapularis & 0.54 & 54 \\
\hline Ma. titillans & 0.45 & 45 \\
\hline Cx. declarator & 0.3 & 30 \\
\hline Ma. indubitans & 0.25 & 25 \\
\hline Cx. gr. coronator & 0.25 & 25 \\
\hline
\end{tabular}

IPSP= Indice de positividade para sangue de primatas.

\subsection{Comportamento sinantrópico de culicídeos.}

O Índice de Sinantropia (IS) foi estimado com base no índice desenvolvido para moscas califorídeos e adaptado para culicídeos, conforme foi descrito na metodologia. O maior Indice de Sinantropia foi registrado para $C x$ quinquefasciatus (IS=31,7), o que vem confirmando o comportamento eusinantrópico endófilo desse mosquito.

Por sua vez, $\boldsymbol{C} x$ chidesteri atingiu um Índice de Sinantropia $($ IS $=27,9)$ sugerindo o processo de adaptação desse culicideo ao ambiente antrópico, desenvolvendo o comportamento eusinantrópico. GOMES \& FORATTINI, em 1990 salientaram a tendência desse culicídeo à urbanização. Esse registro é concordante com os assinalados nesse trabalho.

Entretanto, Ae. scapularis, apesar de ocupar a primeira posição em abundância e dominância de espécies no local e freqüentar o domicílio, apresentou índice sinantrópico negativo (IS $=-19,9)$. Por sua maior freqüência em área de vegetação aberta, permite considerar-lo mosquito hemisinantrópico, como havia sido classificado por FORATTINI e col., $(1993,1995)$. No entanto, o indice obtido nesse trabalho para a mencionada espécie, quando comparado com os publicados por esses autores, não são concordantes, pois os autores referidos encontraram valores indicando maior sinantropia. Isso possivelmente seja devido a que os mesmos são referentes a coletas em ambiente domiciliar inserida em área rural. Além disso, outro motivo pode ser ao fato 
do Parque ser povoado por fauna rica em aves e mamíferos, oferecendo alimento para esse mosquito e, portanto, atraindo-o para fora dos limites domiciliares. Salienta-se que tanto a tendência endófila desse mosquito quanto sua freqüência domiciliar, evidenciam sua adaptação ao ambiente antrópico.

Cx. declarator atingiu o Índice de Sinantropia baixo $\mathbf{I S}=17,4$, indicando sua adaptação ao ambiente alterado. Em adição, a eusinantropia de Aedes albopictus, An. albitarsis, Mansonia indubitans, Mansonia titillans e An. strodei foi também revelada (Quadro 2).

Quadro 2. Índice de Sinantropia das espécies de culicídeos coletados em armadilhas luminosas tipo CDC . no periodo de 1996 a 1998. Parque Ecológico do Tietê. Municipio de Guarulhos. Estado de São Paulo.

\begin{tabular}{|c|c|}
\hline ESPÉCIE & IS \\
\hline Cx. quinquefasciatus & 31,7 \\
\hline Cx. chidesteri & 27.9 \\
\hline Cx. declarator & 17,4 \\
\hline An. albitarsis & 17,1 \\
\hline Ae. albopictus & 16.5 \\
\hline Ma. indubatans & 13.4 \\
\hline Ma. titillans & 7,2 \\
\hline An. strodei & 0,1 \\
\hline Ps. discrucians & 0.01 \\
\hline$C x$. gr.pilosus & 0.0 \\
\hline Cx. ribeirensis & 0.0 \\
\hline Ps. ciliata & 0,0 \\
\hline$C x$. sece Mel & -0.005 \\
\hline Cx. brethesi & -0.01 \\
\hline Cx. bidens & $-0,01$ \\
\hline Ur. lowii & -0.02 \\
\hline Cx. mollis & -0.02 \\
\hline Cx. nigripalpus & -0.03 \\
\hline Ps. ferox & -0.04 \\
\hline An. evansae & $-0,05$ \\
\hline Cq. venezuelensis & -0.05 \\
\hline Ae fluviatilis & -0.05 \\
\hline Cx. coronator & -0.35 \\
\hline Ae. scapularis & -19.9 \\
\hline
\end{tabular}

IS: Indice de Sinantropia. 
Embora o indice de sinantropia proposto por NUORTEVA (1963) para moscas califorideos, permita estimar à adaptação de culicideos em ambiente antrópico, no entanto, tratando-se de culicídeos um outro indice poderia ser elaborado, considerandose além de dados populacionais, dados relativos ao desenvolvimento em criadouros artificiais, sobrevivência, antropofilia e dispersão. O maior grau de sinantropia ou domiciliação poderia ser representado por Ae. aegypti, $\boldsymbol{C}$. quinquefasciatus.

\subsection{Potencial epidemiológico de algumas espécies registradas no local}

O Parque alberga uma fauna de vertebrados como: macacos e aves procedentes de diversos ecossistemas do pais. Nesse habitat torna-se possivel o surgimento de interações hospedeiras principalmente no tocante à introdução e manutenção de arbovirus silvestres devido à presença de espécies de culicideos de reconhecida potencialidade vetorial. Nesse contexto, salienta-se que parte do Parque é destinado ao lazer colocando dessa maneira a comunidade em risco para diversos agravos à saúde

$\mathrm{Na}$ epoca em que foram realizadas as coletas de culicideos desse trabalho, foi isolado no Parque o virus Ilheus (ILH) em aves silvestres no local por (PEREIRA e col., 1994). Esse fato vem confirmando a importância das aves no ciclo silvestre desse agente e na saúde pública, porque representam o risco de disseminação do virus em outras regiões. Nesse contexto a presença de culicídeos de reconhecida importância na transmissão vetorial de Arbovirose no Parque, representa risco para a população

Ae. scapularis é assinalada por possuir competência vetorial para diversas Arbovirose como: a Febre Amarela, Encefalite Equina Venezuelana, Encefalite São Luis, vírus Malao, virus Rocio ( AITKEN e col 1968; CHRISTENSEN e col, 1996; FORATTINI 1961; GUBLER 1996; LHUILLIER e col, 1981; LOPES e col, 1981; MONATH 1993; VAIDYANATHAN e col, 1997; WATTS e col, 1998). Além disso, também foi assinalada sua competência vetorial na transmissão da Dirofilaria immitis e Wuchereria bancrofti (CONSOLI \& LOURENÇO DE OLIVEIRA 1994; LOURENÇO DE OLIVEIRA \& DEANE 1995; LABARTHE e col, 1998;). Nesse trabalho, a mencionada espécie foi tida como mais abundante no local, por sua tendência eusinantropica pode propiciar a emergência de viroses ou facilitar a dispersão de novas viroses, devido ao contato com a população humana. 
Cx. quinquefasciatus é o vetor primário da Filariose Bancroftiana no Brasil. Esse culicideo tem sido encontrado naturalmente infectado com virus da Encefalitis ST Louis, Oeste nos Estados Unidos e Encefalitis Venezuelana no Panamá. Ė considerado altamente antropofilico e endofágico. Sendo abundante no Parque é motivo de incômodo para a população (FORATTINI, 1961; CONSOLI \& LOURENÇO DE OLIVEIRA, 1994). Por sua vez $\boldsymbol{C} \boldsymbol{x}$. declarator também abundante no local, sua importância sanitária diz respeito a ter sido assinalada a competência vetorial para o virus SLE na Região Amazônica Brasileira por VASCONCELOS e col., (1991). Além disso foi também assinalada a potencialidade vetorial de Dirofilaria immitis por LABARTHE e col., (1998).

Embora Ae. albopictus seja registrada com baixa freqüência no local salienta-se a importância sanitária desse culicídeo. Essa espécie é tida como transmissora de vírus da Encefalite Japonesa, Febre Amarela Chichungunya, La Crosse e principalmente da Dengue ao homem. No Brasil numerosas epidemias de Dengue ocorreram e cepas do vírus da dengue 1 e 2, estão sendo dispersos no país, atingindo numerosos centros urbanos. Por outro lado, a Febre Amarela, que atualmente mantém ciclo silvestre , continua ameaçando às cidades infestadas pelo Ae. aegypti e Ae. albopictus. SERUFO e col, 1993 recentemente detectaram virus da Dengue em Ae. albopictus no Estado de Minas Gerais.

Destaca-se tambem a presença de Ps. ferox escassa no local. Essa espécie foi encontrada naturalmente infectada pelo virus da Encefalite Eqüina Venezuelana, virus Ilhéus, virus da Encefalite de São Luís e do Vale Cache e Melão em Belém, vírus Rocio em São Paulo no Brasil (CAUSEY e col 1963 ; LOPES e col 1981). Alem disso a voracidade e agressividade desse culicídeo é causa de incômodo para a população. Outra espécie escassa foi $\boldsymbol{C} \boldsymbol{x}$. ribeirensis sua importância diz respeito por ter sido registrada infetada naturalmente com virus do grupo Bunyavírus (FORATTINI e col 1995c).

Por sua vez, Culex nigripalpus é também escasso no local. Esse culicideo tem sido encontrado infectado por vírus agentes de Encefalites nos Estados Unidos da América, Trinidad e Jamaica. No Brasil, esse mosquito foi assinalado como vetor potencial da Encefalite ST.Louis no Vale do Ribeira, São Paulo ( FORATTINI e col., 
1995 ). Ma titillans foi encontrada portando virus da Encefalite Venezuelana e ovos de Dermatobia hominis, causadora do berne. Ma. titillans e Ma. indubitans são espécies agressivas e motivo de incômodo para a população.

\section{CONCLUSÕES}

O Parque Ecológico do Tietê comporta uma fauna de culicideos bastante diversificada. Embora sejam escassas algumas espécies com potencial epidemiológico como, Ae. albopictus, Ps. ferox, Cx. ribeirensis, $C x$ nigripalpus, An. albitarsis, ressalta-se a marcante presença de outras também de importância sanitária como $A e$. scapularis, $\boldsymbol{C x}$. quinquefasciatus e $\boldsymbol{C x}$. declarator.

Aedes scapularis foi a espécie mais freqüente, de maior dominância e abundància no local. Demostrou tendência endófila, freqüentando $o$ ambiente intradomiciliar, e antropofilia. Estando mais distribuida em área de vegetação aberta, considera-se a espécie como hemisinantrópica. Reforça-se as evidências que assinalam sua adaptação ao ambiente alterado e potencial para desenvolver comportamento eusinantrópico.

Por sua vez, Culex quinquefasciatus e Culex declarator foram também culicideos abundantes no local estudado. Quanto a Culex quinquefasciatus, verificouse a antropofilia e endofilia desse mosquito, obviamente considerado eusinantrópico. Embora Culex declarator, revele antropofilia e freqüente o ambiente domiciliar os resultados sugerem hábito exófilo para a espécie. O Índice de Sinantropia evidencia possivelmente a adaptação desse mosquito ao ambiente alterado.

Apesar de Culex chidesteri ser espécie pouco abundante na área, sua freqüência ao ambiente domiciliar e seu hábito antropofilico sugerem que a mencionada espécie possa estar desenvolvendo comportamento eusinantrópico.

Existe correlação baixa entre a atividade mensal dos culicideos mais freqüentes, a pluviosidade e a temperatura média mensal no local. 
Verificou-se a atividade de Ae. scapularis em ambiente peridomiciliar em horas noturnas e diurnas, com picos no crepúsculo vespertino. Cx. quinquefasciatus mostrouse ativo a partir do crepúsculo vespertino e com picos de maior atividade durante a noite e horários matutinos. Cx: declarator, embora escasso nesse ambiente, revelou maior atividade no crepúsculo vespertino.

Recomenda-se, estudos futuros relativos a criadouros, infecção por vírus, hábitos alimentares, dispersão, à longevidade, taxa de sobrevivência, que visem interpretar a potencialidade de transmissão da população de culicídeos no local.

Recomenda-se a elaboração de um Programa de Vigilância de Vírus na população de vertebrados introduzidos no Parque, na população humana do local, que detecte a possivel introdução de algum agente etiológico no local. Diante do quadro epidemiológico que apresenta o Parque, pode ser considerado como receptivo ou vulnerável, colocando à população em risco.

Recomenda-se também às entidades pertinentes medidas que visem ao controle de $\boldsymbol{C}$. quinquefasciatus, abundante no local, favorecido pelo crescimento desordenado da cidade, com a presença de criadouros representados por córregos poluídos próximos ao local, gerando incômodo à população. 


\section{REFERÊNCIAS}

Aitken THG, Worth ES, Tikasingh ES. Arbovirus studies in Bush forest. Trinidad, W.I, September 1959- December 1964. III. Entomological studies. Am J Trop Med Hyg. $1968 ; 17: 253-68$

Apperson CS, Engber B, Levine JF. Relative suitability of Aedes albopictus and Aedes aegypti in North Carolina to support development of Dirofilaria immitis. J Am Mosq Control Assoc. 1989; $5:$ 377-382.

Bidlingmayer WL. The measurement of adult mosquito population changes: some considerations. J Am Mosq Control Assoc. 1985; 2(1): 324-47

Bruno G. Atividade de Culicídeos em Área de Transição entre o Ambiente Florestal e o Urbano, Região do Vale do Ribeira. Estado de São Paulo; 1997 [Dissertação de Mestrado - Departamento de Epidemiologia da Faculdade de Saúde Pública da USP]

Burkot W \& Defoliart R. Identification of mosquito blood meals by enzyme-linked immunosorbent assay. Am J Trop Med Hyg. 1981; 30: 1336-41

Cabral E. Análise das alterações climáticas da cidade de São Paulo (1887-1995) no contexto da expansão de sua mancha urbana. São Paulo; 1997 [ Dissertação de Mestrado - Departamento de Geografia da Faculdade de Filosofia, Letras e Ciências Humanas da USP ]

Cabral E \& Jesus E. Eventos pluviais concentrados sobre a Grande São Paulo ocorridos em 1991. Seus reflexos na vida urbana. Sitientibus, Feira de Santana 1994; 12: 31 54

Casanova C. Ecologia populacional das fases imaturas de Aedes scapularis Rondani, 1848 (Diptera, Culicidae). Campinas; 1994. [Dissertação de Mestrado - Instituto de Biologia da UNIC AMP] 
Causey OR, Casals J, Shope RE, Usomsakdi S. Aura and Una, two new group A arthopod-borne viruses. Amer J Trop Med Hyg. 1963; 12: 777-81.

Causey OR, Causey CE, Maroja OM, Macedo DG. The isolation of arthopod-borne viruses including members of two hithertoundescribed serological groups, in the Amazon region of Brazil. Amer J Trop Med Hyg. 1960; 10: 227-49.

Christensen HA, de Vasquez AM \& Boreham M. Hot heeding patterns os mosquitoes os mosquitoes (Diptera: Culicidae) from Central Panama. Am J Trop Med Hyg. 1996; 55(2): 202-208

Consoli RAGB, Lourenço De Oliveira $R$. Principais mosquitos de importância sanitária no Brasil. Rio de Janeiro, Ed. FIOCRUZ, 1994.

DAEE. Parque Ecologico do Tietê - Uma idéia a ser aprimorada. Rev Águas e Energia $1989 ; 16: 7-13$.

Day JF, Stark LM. Eastern Equine Encephalites Transmission to Emus (DROMAIUS NOVAEHOLlaNDIAE) In Volusia County Florida: 1992 through 1994. J Am Mosq Control Assoc. 1996; 12(3): 429-436.

Defoliart G, Grimstad P; Watts DM. Advances in mosquito-borne arbovirus/vector research. Ann Rev Entomol 1987; 32: 497-505.

Edrissian GH, Hafizi A. Application of enzyme-linked immunosorbent assay (ELISA) to identification of Anopheles mosquito bloodmeals. Trans of the Royal Soc of Trop Med and Hyg 1982; 76 (1): 54-56.

Faran ME, Linthicum KJ. A handbook of the Amazonian species of Anopheles (Nyssorhynchus) (Diptera:Culicidae) Mosq Systcs 1981;13:1-81

Forattini OP. Entomologia médica. São Paulo, Ed. Universidade de São Paulo, 1965.v.1 
Forattini OP. Entomologia médica. São Paulo. Ed. Universidade de São Paulo, 1965. v. 2 .

Forattini OP. Ecologia, epidemiologia e sociedade. São Paulo, Artes Médicas, EDUSP, 1992

Forattini OP. Culicidologia Médica. São Paulo, EDUSP, 1996. v1

Forattini OP. Some data on the domesticity of Aedes scapularis (RONDANI) in São Paulo, Brazil. Mosq News 1961; 21(4): 295-96.

Forattini OP, Lopes O de S, Rabello EX. Investigações sobre o comportamento de formas adultas de mosquitos silvestres no Estado de São Paulo, Brasil. Rev. Saúde Pública 1968; 2: 111- 73 .

Forattini OP; Ishiata GK; Rabello EX \& Cotrim M das. Observações sobre os mosquitos Culex da cidade de São Paulo, Brasil. Rev Saúde Pública 1973; 7 : 315-30.

Forattini OP, Gomes AC, Galati EAB, Rabello EX, Iversson LB. Estudos ecológicos sobre mosquitos Culicidae no sistema da Serra do Mar, Brasil. 1. Observações no ambiente extradomiciliar. Rev. Saúde Pública 1978; 12: 297-325.

Forattini OP, Gomes AC, Galati EAB, Rabello EX, Iversson LB. Estudos ecológicos sobre mosquitos Culicidae no sistema da Serra do Mar. 2. Observações no ambiente domiciliar. Rev. Saúde Pública 1978 a; 12: 476 - 96.

Forattini OP, Gomes AC de, Santos J, Galati E, Rabello E, Natal D. Observações sobre atividade de mosquitos Culicidae em mata residual no Vale do Ribeira, São Paulo, Brasil. Rev Saúde Pública 1981; 15 : 557-86.

Forattini OP, Gomes AC de, Natal D, Santos J. Observações sobre atividade de mosquitos Culicidae em mata primitiva da encosta do Vale do Ribeira, São Paulo, Brasil. Rev Saúde Pública 1986; 20(1): 1-20. 
Forattini OP, Gomes AC de, Natal D, Santos J. Observações sobre atividade de mosquitos Culicidae em matas primitivas da planície e perfis epidemiológicos de vários ambientes no Vale de Ribeira, São Paulo, Brasil. Rev Saúde Pública 1986; 20: 178203

Forattini OP, Gomes AC, Natal D, Kakitani I, Marucci D. Preferências alimentares de Mosquitos Culicidae no Vale do Ribeira, São Paulo, Brasil. Rev. Saúde Pública 1987; 21: $171-87$

Forattini OP, Gomes AC, Natal D, Kakitani I, Marucci D. Freqüência domiciliar e endofilia de mosquitos Culicidae no Vale do Ribeira, São Paulo, Brasil. Rev. Saúde Pública 1987 a, 21: 188-92.

Forattini OP, Gomes AC. Biting activity of Aedes scapularis ( Rondani) and Haemagogus mosquitoes in Southern Brazil (Diptera: Culicidae ). Rev. Saúde Pública $1988 ; 22: 84-93$

Forattini OP, Gomes AC de, Natal D, Kakitani I, Marucci D. Preferências alimentares e domiciliação de mosquitos Culicidae no Vale do Ribeira, São Paulo, Brasil com especial referència a Aedes scapularis e a Culex (Melanoconion). Rev Saúde Pública $1989 ; 23: 9-19$

Forattini OP, Gomes AC de, Santos JL, Kakitani;I, Marucci, D. Freqüência ao ambiente humano e dispersão de mosquitos Culicidae em área adjacente à Mata Atlântica primitiva da planicie. Rev Saúde Pública 1990, 24: 101-7

Forattini OP. Gomes AC, Kakitani I, Marucci D. Observações sobre a domiciliação de mosquitos Culex (Melanoconion), em ambiente com acentuadas modificações antrópicas. Rev Saúde Pública 1991; 25(4): 257-66

Forattini OP, Kakitani I, Massad E, Marucci D. Studies on mosquitoes (Diptera Culicidae) and anthropic environment. 4. Survey of resting adults and synanthropic behaviour in South Eastern, Brasil. Rev Saúde Pública 1993; $27: 398-411$ 
Forattini OP, Kakitani I, Massad E, Marucci D. Studies on mosquitoes (Diptera Culicidae) and anthropic environment. 9 - Synanthropy and epidemiological vector role of Aedes scapularis in South-Eastern Brazil. Rev Saúde Pública 1995; 29(3): 199-207.

Forattini OP, Kakitani I, Massad E, Marucci D. Studies on mosquitoes ( Diptera: Culicidae ) and anthropic environment. 10- Survey of adult behaviour of Culex nigripalpus and other species of Culex (Culex) in South- Eastern Brazil. Rev Saúde Pública 1995; 29 (4): 271-8.

Forattini OP, Sallum MAM, Kakitani I, Massad E, Marucci D. Studies on mosquitoes (Diptera: Culicidae) and anthropic environment. 8. Survey of adult behavior of Spissipes Section species of Culex (Melanoconion) in South- Eastern Brazil. Rev Saúde Pública 1995b; 29(2):100-7.

Forattini OP, Kakitani I, Sallum MAM. Breeding places of Aedes scapularis (Diptera: Culicidae) in artificial containers. Rev Saúde Pública 1997; 31(5): 519-22.

Frankie GW, Ehler LE. Ecology of insects in urban environments. Ann Rev Entomol $1978 ; 23: 367-87$

Gomes AC. Mecanismo e significado epidemiológico da domiciliação. Rev Saúde Pública $1986 ; 20: 385-90$.

Gomes AC, Forattini OP. Abrigos de mosquitos Culex (Culex) em zona rural (Diptera: Culicidae). Rev Saúde Pública 1990; 24: 394-7.

Gomes AC, Forattini OP, Kakitani I, Marques GR, Marques CCA, Marucci D, Brito M. Microhábitats de Aedes albopictus (Skuse) na região do Vale do Paraíba, Estado de São Paulo, Brasil Rev Saúde Pública 1992; 26(2): 108-18

Gordon S. Urbanization and the epidemiology of mosquito borne- disease. Abs Hyg. $1971 ; 46: 121-34$. 
Gubler DJ. The global resurgence of arboviral diseases. Trans Trop Med Hyg 1996; 90: 449-51

Guimarães AE, Arlé M. Mosquitos do Parque Nacional da Serra dos Órgãos, Estado do Rio de Janeiro, Brasil. I. Distribuição espacial. Mem. Inst. Oswaldo Cruz 1984; 79 : $309-23$

Guimarães AE, Victório VMN. Mosquitos no Parque Nacional da Serra dos Órgãos, Estado do Rio de Janeiro, Brasil III. Preferência horária para a hematofagia. Mem. Inst. Oswaldo Cruz 1986; 81 (1): 93-103

Guimarães AE, Arlé M, Machado R. Mosquitos no Parque Nacional da Serra dos Órgãos, Estado do Rio de Janeiro, Brasil. IV. Preferência Alimentar. Mem Inst Oswaldo Cruz 1987; 82(2): 277-85

Haddow AJ. Studies on the biting-habits of african mosquitoes: an apprasial of methods employed with special reference to the twenty- four hour catch. Bull Ent Res 1954; 45 : $199-242$

Haddow AJ. Studies on the biting habits and medical importance of east african mosquitoes in the genus Aedes. Bull Ent Res 1960; 50: 759-779.

Iversson LB. Rocio encephalitis. In: Monath, T.P. Arboviruses: epidemiology and ecology. Boca Raton, CRE Press; 1988 v.4 p.77- 92

Karabatsos N. International catalog of Arboviruses Including Certain Other Viruses of Vertebrates $3^{\text {rd }}$ edition. San Antonio, Texas: Am erican Society Of Tropical Medicine and Hygiene. Editor 1985.

Knudsen AB, Slooff $R$. Vector-borne disease problems in rapid urbanization. New aprrovaches to vector control. Bull World Health Organ 1992; 70: 1-6. 
Konishi E. Culex tritaeniorhynchus and Aedes albopictus (Diptera: Culicidae) as natural vectors of Dirofilaria immitis (Spirurida: Filariidae) in Miki city, Japan. J Med Entomol 1989 a; 26: 294-300.

Konishi E. Susceptibility of Aedes albopictus and Culex tritaeniorhynchus (Diptera: Culicidae) colected in Miki city, Japan. to Dirofilaria immitis (Spirurida: Filariidae). J Med Entomol 1989b; 26: 420-423.

Kostrowicki S. Synanthropization as a result of environmental transformations. Memorabilia zoológica 1982; 37:3-10

Labarthe N, Serrão ML, Melo FY, De Oliveira SJ, Lourenço-de Oliveira R. Potencial vectors of Dirofilaria immitis ( Leidy, 1856 ) in Itacoatiara, Oceanic Region of Niterói Municipality, State of Rio de Janeiro, Brazil. Mem Inst Oswaldo Cruz 1998; 93(4) 425-32.

Labarthe N, Serrão ML, Melo FY,De Oliveira SJ, Lourenço-de Oliveira R. Mosquito frequency and feeding habits in an enzootic canine Dirofilariasis in Niterói, State of Rio de Janeiro, Brazil. Mem Inst Oswaldo Cruz 1998; 93 (2): 145-154.

Lane J. Neotropical Culicidae. Universidade de São Paulo 1953; 731-47.

Lhuillier M, Pajot FX, Mouchet J, Robin Y. Arboviroses en Amerique du Sud et dans les Caraibes. Méd Trop. 1981; 41:73-84.

Linthicum KJ. A revision of the Argyritarsis section of the subgenus Nyssorhynchus of Anopheles. Mosq Syst 1988; 20: 98-271.

Lopes J, Lozovei AL. Ecologia de mosquitos (Diptera:Culicidae) em criadouros naturais e artificias de rea rural do Norte do Estado do Parana, Brasil. I. Coletas ao longo do leito de ribeirão. Rev Saúde Pública 1995; 29(3): 183-91. 
Lopes OS, Coimbra TLM, Sacchetta LA. Emergence of a new arbovirus disease in Brazil. I. Isolation and characterization of the etiologic agent, Rocio virus. Am J Epidemiol 1978; 107: 444-9.

Lopes OS, Sacchetta LA. Coimbra TLM. Emergence of a new arbovirus disease in Brazil. II. Epidemiological studies on 1975 epidemic. Am J Epidemiol 1978 a; 108: 394-401.

Lopes OS, Sacchetta LA, Francy D, Jakob W, Calisher CH. Emergence of new arbovirus disease in Brazil.III. Isolation of Rocio Virus From Psrophora ferox (Humboldt, 1819) Am J of Epidemiol 1981; 113 (2): 122-25.

Lopes J. Ecology in natural and artificial rural breeding places in northern Parana, Brazil. V. Larval collection in artificial containers installed in ciliary forest. Rev. Saúde Pública 1997; Aug; 31(4): 370-7.

Lourenço de Oliveira R. Alguns aspectos da ecologia de mosquitos (Diptera: Culicidae) de uma planicie (Granja Calábria), em Jacarepaguá, Rio de Janeiro. I. Freqüencia comparativa das espécies em diferentes ambientes e métodos de coleta. Mem. Inst. Oswaldo Cruz 1984; 79 : 479-90.

Lourenço de Oliveira R, Silva T. Alguns aspectos da ecologia dos mosquitos (Diptera: Culicidae) de uma área de planicie ( Granjas Calábria ), em Jacarepaguá, Rio de Janeiro. III. Preferência horária das fềmeas para o hematofagismo. Mem Inst Oswaldo Cruz $1985 ; 80(2)$ : 195-201.

Lourenço de Oliveira R, Heyden R. Alguns aspectos da ecologia dos mosquitos (Diptera: Culicidae) de uma área de planície ( Granjas Calábria ), em Jacarepaguá, Rio de Janeiro. IV. Preferências alimentares quanto ao hospedeiro e frequência domiciliar. Mem Inst Oswaldo Cruz 1986; 81(1): 15-27.

Lourenço de Oliveira R. Deane L. Presumed Dirofilaria immitis infections in Wildcaught Aedes taeniorhynchus and Aedes scapularis in Rio de Janeiro, Brazil. Mem Inst Oswaldo Cruz 1995; 90: 387-388 
Macêdo F, Labarthe N, Lourenço-de Oliveira R. Susceptibility of Aedes scapularis (Rondani, 1848) to Dirofilaria immitis ( Leidy, 1856 ), an emerging zoonosis. Mem Inst Oswaldo Cruz 1998; 93(4): 435-37.

Marques G.R. Comportamento antropofílico de culicídeos da região do Vale do Paraíba, com especial referência ao Ae. albopictus. São Paulo; 1994 [Dissertação de Mestrado- Departamento de Epidemiologia da Faculdade de Saúde Pública da USP]

Menezes RM. Composição e Atividade de mosquitos (Diptera:Culicidae) da Área de Influência Indireta das Hidrelétricas de Canoas I e II. Bacia do Rio Paranapanema- PR, 1993 a 1995. São Paulo; 1997.[Dissertação de Mestrado Departamento de Epidemiologia da Faculdade de Saúde Pública da USP]

Mitchael J , Forattini O. Experimental transmission of Rocio Encephalitis Virus by Aedes scapularis (Diptera: Culicidae) from the epidemic zone in Brazil. $\boldsymbol{J}$ Med Entomol 1984; $21: 34-36$.

Mitchael J, Monath P, Sabattini S, Cropp B, Daffner F, Calisher H, Jakob L, Christensen A. Arbovirus investigations in Argentina, 1977-1980. II. Arthropod collections and virus isolations from Argentine mosquitoes. Am J Trop Med Hyg $1985 ; 34: 945-55$

Mitchael J, Forattini O, Muller B. Vector competence experiments with Rocio virus and three mosquito species from the epidemic zone in Brazil. Rev Saúde Pública 1986; 20 171-7.

Mitchael J, Turell J, Joseph R; Gary W. Experimental transmission of eastern equine encephalitis virus by strains of Aedes albopictus and Ae. taeniorhynchus ( Diptera Culicidae). J Med Entomol 1994; $31: 287-90$.

Monath TP. Arthropod-borne viruses. In: Stephen SM. ed. Emerging viruses. New York, Oxford University Press 1993, p 138-48 
Nasci RS. A light weight batterypowered aspirator for collecting resting mosquitoes in the field. Mosq News 1981; $41: 808-11$

Natal D. Observações sobre o comportamento de mosquitos (Diptera:Culicidae) em área de matas residuais no Vale do Ribeira, Estado de São Paulo, Brasil; 1986 [Tese de Doutorado - Departamento de Epidemiologia da Faculdade de Saúde Pública da USP]

Natal D, Paganelli CH, Santos, JLF. Composição da população adulta de Culex (Culex) quinquefasciatus Say, 1823 em ecótopos próximos à represa Edgar de Souza, no Município de Santana de Paraiba, Estado de São Paulo, Brasil. Rev Bras Entomol $1991 ; 35: 539-43$

Natal D, Urbinatti,PR, Taipe-Lagos CB, Ceretti-Junior W, Diederichsen ATB, Souza RG, Souza RP. Encontro de Aedes (Stegomyia) albopictus (Skuse) em Bromeliaceae na periferia de São Paulo, SP, Brasil. Rev Saúde Pública 1997; 31 : 517-8.

Nuorteva P. Synanthropy of blowflies (Diptera: Calliphoridae) in Finland. Ann Entomol Fenn 1963; 29:1-44.

Oberste MS, Weaver SC, Watts DM, Smith JF. Identification and Genetic Analysis of Panama- Genotype Venezuelan Equine Encephalitis Virus Subtype id in Peru Am J Trop Med Hyg 1998; 58(1): 41-46.

Pereira LE, Suzuki A, Coimbra TLM, Souza RP de, Chamelet ELB. Presença do arbovírus Ilhéus (ILH) em aves silvestres (Sporophila caerulescens, Molothrus bonarienses) no Estado de São Paulo, Brasil. In: Resumo da $2^{\text {a }}$. Reunião Anual do Instituto Adolfo Lutz 1997 set 22-25; São Paulo. p 252.

Povolny D. Synanthropy. In: Greenberg, B, ed. Flies and disease. Princeton, Princeton Univ.Press, 1971.v.1, p. 16-54.

Reisen WK. Estimation of vectorial capacity: Relationship to disease transmission by malaria and arbovirus vectors. Bull Soc Vector Ecol 1989; 14: 67-70. 
Roberts DR, HSI BP. An Index of Species Abundance for Use with Mosquito Surveillance Data. Environ Entomol 1979; 8(6): 1007-13.

Roberts R, Hoch A, Peterson N, Pinheiro F. Programa Multidisciplinario de Vigilancia de las Enfermedades infecciosas en zonas colindantes con la carretera Transamazónica en Brasil. IV. Estudio Entomológico. Bol Of Sanit Panam 1981; 91(5): 379-97.

Roberts R, Peyton L, Pinheiro P, Balderrama F, Vargas R. Asociación de vectores de arbovirus con galerias arboreas y el medio doméstico en el Sureste de Bolivia. Bol Of Sanit Panam 1985; 98: 417-29.

Rocha A. A. Hidrobiologia sanitária e saúde pública em lagos do Parque Ecológico, zona leste, São Paulo. São Paulo;1990. (Relatório de pesquisa apresentado à FAPESP).

Rodrigues-Silva R, Moura H, Dreyer G, Rey L. Human Pulmonary Dirofilariasis: A Review. Rev Inst Med Trop S Paulo 1995; 37(6): 523-27.

Sallum MAM. Revisão da seção Spissipes de Culex (Melanoconion) (Diptera: Culicidae). São Paulo; 1994 [Tese de Doutorado-Faculdade de Saúde Pública da USP ].

Sauerman DM, Nayar JK. A survey for natural potential vectors of Dirofilaria immitis in Vero Beach, FL. Mosq News 1983; 43: 222-25

Savage HM, Niebylski ML, Smith GC, Mitchell CJ, Craig GB. Host-feeding Patterns of Aedes albopictus (Diptera: Culicidae) at a temperate North American Site. J Med Entomol 1993; 30(1): 27-34.

Savage HM, Duncan J, Roberts O, Sholdt L. A dipstick ELISA for rapid detection of human blood meals in mosquitoes. J AM Mosq Control Assoc 1991; 7: 16-23

Serufo JC, Oca HM, Tavares VA, Souza AM, Rosa RV, Jamal MC, Lemos JR, Oliveira MA, Nogueira RMR, Schatzmayer HG. Isolation of Dengue virus type 1 from larvae of 
Aedes albopictus in Campos Altos City, state of Minas Gerais, Brazil. Mem Inst Oswaldo Cruz 1993; 88(3): 503-4.

Service MW. Mosquito Ecology. Sampling adults by animal baitep traps. London, Ed.Applied Science pp 221-35, 1993.

Service MW. A critical review of procedures for sampling populations of adult mosquitoes. Bull Ent Research. 1977; 6:343-82.

Shannon R. Methods for collecting and feeding mosquitos in jungle yellow fever studies. Am J Trop Med Hyg 1939; 19: 131-40.

Silva AM, Menezes RM. Encontro de Aedes scapularis (Diptera: Culicidae) em criadouro artificial em localidade da região Sul do Brasil. Rev Saúde Pública 1996; $30(1): 103-4$

Soper FL, Penna HA, Cardoso E, Serafim Jr J, Frobisher Jr M, Pinheiro J. Yellow fever without Aedes aegypti study of rural epidemic in Vale do Chanaan, Espírito Santo, Brasil, 1932. Am J Hyg. 1933; 18:555-87.

Soubihe V. Estudo de populações de mosquitos culicídeos no Parque Ecológico do Tietê, SP, Brasil (Diptera: Culicidae). São Paulo; 1994 [Dissertação de MestradoInstituto de Ciências Biomédicas da USP São Paulo].

Sounis E. Bioestatística. Rio de Janeiro. $3^{\mathrm{a}}$ Edição, Atheneu, 1985.

Southwood TER. Ecological methods. $2^{\text {nd }}$ ed.London, Chapman and Hall, 1978.

Sudia WD, Chanberlain RW. Batery-operated light trap, an inproved model. Mosq News 1962; 22(2): 126-29.

Suzuki A, Tubaki RM, Pereira LE, Chamelet E. Mosquitos naturalmente infectados pelo arbovírus Ilheus, no Estado de São Paulo. In: Resumo da $2^{\mathbf{a}}$. Reunião Anual do Instituto Adolfo Lutz 1997 set 22-25; São Paulo. p 251. 
Taipe-Lagos CB, Natal D, Urbinatti PR, Ceretti WJ. Synanthropy of mosquitoes (Diptera, Culicidae) in preserved area in the outskirts of an urban ecosystem, São Paulo, Brazil. Acta Parasitol Port 1998; 5 (1): abstr 0-12.

Tempelis $\mathrm{CH}$, Lofy MFA. A modified precipitin method for identification of mosquito blood meals. Am J Trop Med Hyg 1963; 12: 825-31.

Teodoro U, Guilherme AL, Lozovei AL, Filho V, Sampaio A, Spinosa R, Ferreira ME, Barbosa O, De Lima EM. Mosquitos de ambientes peri e extradomiciliares na região sul do Brasil. Rev Saúde Pública 1994; 28(2): 107-15.

Teodoro U, Guilherme ALF, Lozovei AL, Filho V, Fukushigue Y, Spinosa RP, Ferreira MEMC, Barbosa OC De, Lima EM. Culicídeos do Lago de Itaipu, no Paraná, Sul do Brasil. Rev. Saúde Pública 1995; 29: 6 -14

Urbinatti PR, Natal D, Barata JMS, Taipe-Lagos CB, Ceretti, WJ. Low frequency of Aedes albopictus in a preserved area in the outskirts of an urban ecosystem , São Paulo, Brazil. Acta Parasitol Port 1998; 5 (1): abstr 0-3.

Vaidyanathan R, Edman JD, Cooper LA, Scott TW. Vector competence of Mosquitoes (Diptera: Culicidae) from Massachussetts for a Sympatric isolate of eastern equine encephalomyelitis virus. J Med Entomol 1997; 34(3): 346-352.

Vasconcelos PF da C, Travassos Da Rosa JFS, Travassos Da Rosa Apde A, Degallier $N$, Pinheiro $F$ de $P$, Sá Filho GC. Epidemiologia da encefalites por arbovírus na Amazônia brasileira. Rev Inst Med Trop S Paulo 1991; 33:465-76.

Waddell MB. Comparative efficacy of certain South American Aedes and Haemagogus mosquitoes as loboratory vectors of yellow fever. Am J Trop Med 1949; 29: 567-75.

Washino RK, Tempelis CH. Mosquito host blood meal identification: Methodology and data analysis Ann. Rev.Entomol 1983; 28: 179 - 201. 
Watts DM, Callahan J, Rossi C, Oberste SM, Roehrig JT, Wooster MT, Smith JF, Cropp CB, Gentrau EM, Karabatsos N, Gubler D, Hayes CG. Venezuelan equine encephalitis febrile cases among humans in the Peruvian Amazon River region. Am J Trop Med Hyg 1998; 58(1):35-40

Weitz, B. Identification of blood meals of blood-sucking arthropods. Bull WHO 1956; 15: $473-90$

Willis F, Nasci R. Aedes albopictus (Diptera: Culicidae) population density and structure in Southwest Louisiana. J. Med. Entomol 1994, 31:594-99. 
ANEXOS 
FICHA DE CAMPO PARA COLETA DE MOSQUITOS

$\mathrm{N}^{0} \mathrm{COL}:$

DATA: )

\section{I.HORÁRIO ( Hor.)}

01 manhã

$(10-11$ hrs $)$

02 manhã

(11-12hrs)

03 tarde

$(14-15 \mathrm{hrs})$

04 tarde

$(15-16 \mathrm{hrs})$

05 tarde

$(16-17 \mathrm{hrs})$

06 crepúsculo vespertino

071 hra pós crepúsculo.

\section{II.HABITAT ( Hab.)}

01 mata solo

02 aberto

03 intradomicílio

04 peridomicílio

\section{III.TÉCNICA (Téc.)}

01 Aspirador a bateria (mega)

02 Aspirador elétrico (pequeno

03. Aspirador elétrico + isca humana + isca luminosa

04 Aspirador -boca

05 Puça

06 Caixas de repouso

$07 \mathrm{CDC} / \mathrm{luz}+\mathrm{CO} 2$

08 Tubo mortífero

09 Shannon/ aspirador elétrico

10 Shannon/tubo mortifero

11 Shannon/aspirador boca

IV. OBSERVAÇÕES: 
FICHA DE LABORATÓRIO PARA MOSQUITOS ADULTOS

$\mathrm{N}^{0} \mathrm{COL}:($

DATA : ( 11

Horário:

Sexo (Sex.)

1. Macho

2. Fémea

9. col. neg

\section{IDENTIFICAÇÃO}

$\mathrm{Sp}$

$\mathrm{Sp}$

$\mathrm{Sp}$

$\mathrm{Sp}$

$\mathrm{Sp}$

$\mathrm{Sp}$

$\mathrm{Sp}$

$\mathrm{Sp}$
Habitat: $(\quad)$

Espécie (Esp.)

(ver lista Cód. esp.)

col. neg. 999
Técnica:

Precipitina (Precip.)

1. positivo

2. negativo

3. Não testado

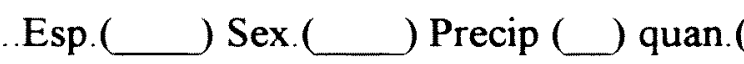

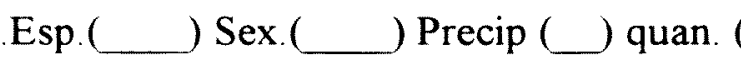

Esp. $\left(\right.$ Sex. $\left({ }^{\longrightarrow}\right.$ Precip () quan.

Esp.

) Sex.(

) Precip ( $\square$ quan.

Esp.

) Sex.(

) Precip $($ quan.

Esp.

) Sex.(

) Precip (ـ) quan.

Esp

) Sex.( Precip ( $($ quan.

Esp

) Sex (

) Precip $($ quan. 
LISTA DO MATERIAL ENTOMOLÓGICO DEPOSITADO NA COLEÇÃO CIENTÍFICA DA FSP-USP.

$\begin{array}{ll}\text { Aedes albopictus } & \text { E } 11963 \\ \text { Aedes scapularis } & \text { E } 11971 \\ \text { Anopheles albitarsis } & \text { E } 11979 \\ \text { Anopheles strodei } & \text { E } 11967 \\ \text { Culex brethesi } & \text { E } 11974 \\ \text { Culex chidesteri } & \text { E } 11970 \\ \text { Culex declarator } & \text { E } 11972 \\ \text { Culex grupo coronator } & \text { E } 11976 \\ \text { Culex mollis } & \text { E } 11980 \\ \text { Culex nigripalpus } & \text { E } 11977 \\ \text { Culex quinquefasciatus } & \text { E } 11975 \\ \text { Culex (mel) ribeirensis } & \text { E } 11965 \\ \text { Mansonia indubitans } & \text { E } 11969 \\ \text { Mansonia titillans } & \text { E } 11968 \\ \text { Psorophora ciliata } & \text { E } 11964 \\ \text { Psorophora discrucians } & \text { E } 11966 \\ \text { Psorophora ferox } & \text { E } 11963 \\ \text { Uranotaenia lowii } & \text { E } 11973\end{array}$


PROGRAMA DE GERENCIAMENTO DO BANCO DE DADOS EM DBASE

Field

1

2

3

4

5

6

7

8

9

10

TOTAL
Field Name

Ncoleta

Dia

Mês

Ano

Horário

Hábitat

Técnica

Sexo

Espécie

Quant

22
4

Width

4

2

2

2

1

1

1

1

3 
get translate file ' Icarmen lsipet 1.dbf' / type db3.

variable labels ncoleta 'num coleta'

$$
\begin{aligned}
& \text { /horario 'horario' } \\
& \text { /habitat 'habitat' } \\
& \text { /tecnica 'tec coleta' } \\
& \text { /sexo 'sexo' } \\
& \text { /especie 'especie' } \\
& \text { /quanti 'quantidade'. }
\end{aligned}
$$

value labels horario

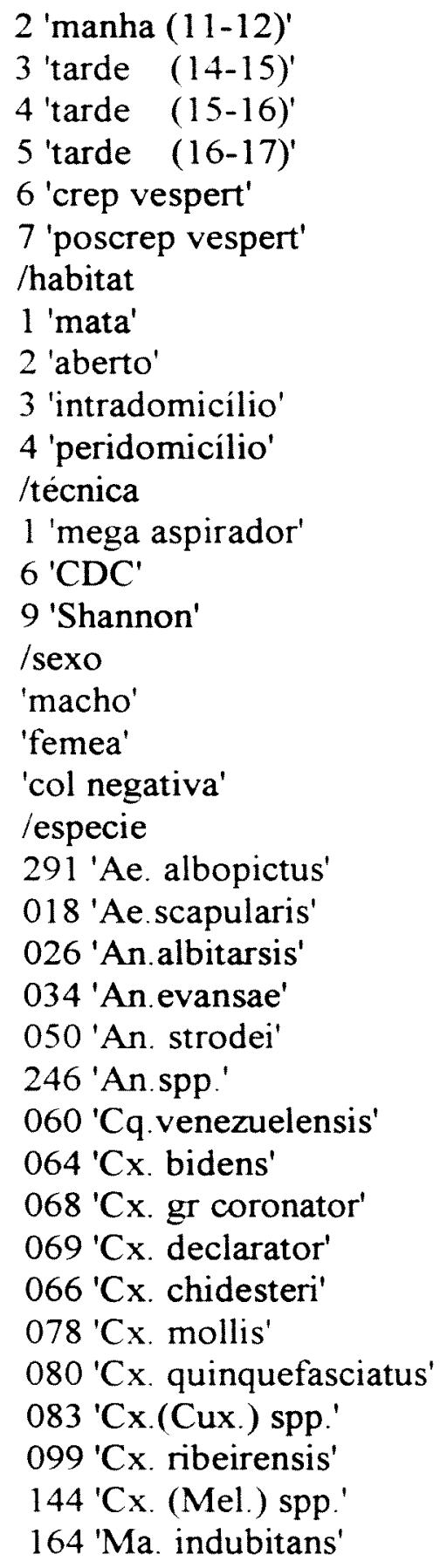


169 'Man (Man.) spp'

285 'Ma. (Man.)titillans'

175 'Ps. ciliata'

180 'Ps.discrucians'

181 'Ps. ferox'

214 'Ur.lowii'

311 'Cx.(Cux) brethesi'

007 'Ae. fluviatilis'

999 'coleta negativa'

SAVE OUTFILE 'CARMEN|SIPET1.SAV'. 


\section{A6}

Tabela 17. Apresentação tabular de dados para o cálculo do coeficiente de correlação de Pearson ( $\mathbf{r}$ ) segundo atividade mensal de Ae. scapularis e pluviosidade no Parque Ecológico do Tietê. Guarulhos. São Paulo. $1996-1998$.

\begin{tabular}{|c|c|c|c|c|c|c|c|}
\hline Mês & $\begin{array}{l}X w \% \\
\text { (v.x) }\end{array}$ & $\begin{array}{l}\text { ppmm } \\
\text { (v.y) }\end{array}$ & $\begin{array}{c}\text { Desvi } \\
0 \\
\text { de } x\end{array}$ & $\begin{array}{c}\text { Desvio } \\
\text { de y }\end{array}$ & $x^{2}$ & $\mathrm{Y}^{2}$ & $X Y$ \\
\hline A & 0,0 & 37 & -15 & $-101,9$ & 225 & 10383,61 & 1528,5 \\
\hline $\mathrm{S}$ & 0,0 & 148 & -15 & 9,1 & 225 & 82,81 & $-136,5$ \\
\hline 0 & 7,8 & 217 & $-7,2$ & 78,1 & 51,84 & 6099,61 & $-562,32$ \\
\hline$N$ & 70,1 & 92 & 55,1 & $-46,9$ & 3036,01 & 2199,61 & $-2584,19$ \\
\hline D & 22,1 & 220 & 7,1 & 81,1 & 50,41 & 6577,21 & 575,81 \\
\hline $\mathrm{J}$ & 1,0 & 227 & $-14,0$ & 88,1 & 196 & 7761,61 & $-1233,4$ \\
\hline$F$ & 9,6 & 266 & $-5,4$ & 127,1 & 29,16 & 16154,41 & $-686,34$ \\
\hline$M$ & 4,3 & 116 & $-10,7$ & $-22,9$ & 114,49 & 524,41 & 245,03 \\
\hline A & 7,0 & 36 & -8 & $-102,9$ & 64 & 10588,41 & 823,2 \\
\hline$M$ & 1,0 & 70 & -14 & $-68,9$ & 196 & 4747,21 & 964,6 \\
\hline$J$ & 4,0 & 97 & -11 & $-41,9$ & 121 & 1755,61 & 460,9 \\
\hline$J$ & 8,7 & 6 & $-6,3$ & $-132,9$ & 39,69 & 17662,41 & 837,27 \\
\hline$A$ & 0,0 & 21 & -15 & $-117,9$ & 225 & 13900,41 & 1768,5 \\
\hline $\mathrm{S}$ & 0,0 & 102 & -15 & $-36,9$ & 225 & 1361,61 & 553,5 \\
\hline 0 & 8,8 & 106 & $-6,2$ & $-32,9$ & 38,44 & 1082,41 & 203,98 \\
\hline $\mathrm{N}$ & 38,4 & 126 & 23,4 & $-12,9$ & 547,56 & 166,41 & $-301,86$ \\
\hline$D$ & 17,2 & 158 & 2,2 & 19,1 & 4,84 & 364,81 & 42,02 \\
\hline $\mathrm{J}$ & 5,0 & 208 & -10 & 69,1 & 100 & 4774,81 & $-691,0$ \\
\hline$F$ & 29,2 & 319 & 14,2 & 180,1 & 201,64 & 32436,01 & 2557,42 \\
\hline$M$ & 65,8 & 207 & 50,8 & 68,1 & 2580,64 & 4637,61 & 3459,48 \\
\hline $\begin{array}{l}\text { Total } \\
\text { Média }\end{array}$ & $\begin{array}{c}300,0 \\
M x=15\end{array}$ & $\begin{array}{c}2779 \\
M y= \\
138,9\end{array}$ & 0 & 1 & $\begin{array}{c}\sum x^{2}= \\
82271,72\end{array}$ & $\begin{array}{c}\Sigma y^{2}= \\
186088,06\end{array}$ & $\begin{array}{l}\Sigma(X Y)= \\
7824,6\end{array}$ \\
\hline
\end{tabular}

$X w \%=$ Média de Williams ( $v=$ variavel $x)$.

ppmm= precipitação média mensal em milimetros de chuva $(v y=$ variável y $)$ 
Tabela 18. Apresentação tabular dos dados para o cálculo do coeficiente de correlação de Pearson ( $\mathbf{r}$ ) segundo a atividade de Ae. scapularis e temperatura no Parque Ecológico do Tietê, Guarulhos, São Paulo, 1996 a 1998.

\begin{tabular}{|c|c|c|c|c|c|c|c|}
\hline Mês & $\begin{array}{l}X w \% \\
(v . x)\end{array}$ & $\begin{array}{c}\text { Temperatura } \\
\text { (v.y ) }\end{array}$ & $\begin{array}{c}\text { Desvio } \\
\text { de } X(x- \\
M x)\end{array}$ & $\begin{array}{c}\text { Desvio } \\
\text { de Y (y- } \\
\text { My) }\end{array}$ & $X^{2}$ & $\mathrm{Y}^{2}$ & $X Y$ \\
\hline $\mathrm{A}$ & 0.0 & 17 & -15 & -3.9 & 225 & 15.21 & 58,5 \\
\hline $\mathrm{S}$ & 0.0 & 18,1 & -15 & -2.8 & 225 & 7,84 & 42 \\
\hline $\mathrm{O}$ & 7.8 & 19.8 & -7.2 & -1.1 & 51.84 & 1,21 & 7,92 \\
\hline $\mathbf{N}$ & 70.1 & 20.2 & 55,1 & -0.7 & 3036,01 & 0.49 & -38.57 \\
\hline $\mathrm{D}$ & 22.1 & 22.4 & 7.1 & 1.5 & 50.41 & 2,25 & 10,65 \\
\hline $\mathrm{J}$ & 1.0 & 22,4 & $-14,0$ & 1.5 & 196 & 2,25 & -21 \\
\hline$F$ & 9.6 & 23.0 & -5.4 & 2.1 & 29.16 & 4,41 & $-11,34$ \\
\hline $\mathrm{M}$ & 4.3 & 21.5 & -10.7 & 0.6 & 114.49 & 0,36 & $-6,42$ \\
\hline A & 7.0 & 20.2 & -8 & -0.7 & 64 & 0,49 & 5,6 \\
\hline $\mathrm{M}$ & 1.0 & 17,9 & -14 & -3 & 196 & 9 & 42 \\
\hline $\mathrm{J}$ & 4.0 & 16.7 & -11 & -4.2 & 121 & 17.64 & 46,2 \\
\hline $\mathrm{J}$ & 8.7 & 17.8 & $-6,3$ & $-3,1$ & 39,69 & 9.61 & 19,53 \\
\hline A & 0.0 & 17.8 & -15 & -3.1 & 225 & 9.61 & 46.5 \\
\hline $\mathrm{S}$ & 0.0 & 19.5 & -15 & -1.4 & 225 & 1,96 & 21 \\
\hline $\mathrm{O}$ & 8.8 & 21.5 & -6.2 & 0.6 & 38,44 & 0.36 & $-3,72$ \\
\hline $\mathrm{N}$ & 38.4 & 23.9 & 23.4 & 3 & 547.56 & 9 & 70.2 \\
\hline $\mathrm{D}$ & 17.2 & 24,9 & 2.2 & 4 & 4.84 & 16 & 8.8 \\
\hline $\mathrm{J}$ & 5.0 & 25.1 & -10 & 4.2 & 100 & 17,64 & -42 \\
\hline $\mathrm{F}$ & 29.2 & 24,6 & 14,2 & 3.7 & 201,64 & 13,69 & 52,54 \\
\hline$M$ & 65.8 & 23.2 & 50.8 & 2.3 & 2580.64 & 5.29 & 116,84 \\
\hline $\begin{array}{l}\text { Total } \\
\text { Média }\end{array}$ & $\begin{array}{c}300 \\
\mathrm{Mx}=15\end{array}$ & $\begin{array}{c}417.5 \\
M y=20.9\end{array}$ & 0 & $-0,5$ & $\Sigma x^{2}=8271,72$ & $\Sigma y^{2}=144,31$ & $\Sigma(X Y)=425,23$ \\
\hline
\end{tabular}

$\mathrm{X} w \%=$ Média de Williams $(\mathrm{V} \cdot \mathrm{x}=$ variável $\mathrm{x})$.

Temperatura média mensal $\left({ }^{\circ} \mathrm{C}\right)(\mathrm{v} \cdot \mathrm{y}=$ variável $\mathrm{y})$. 


\section{A7}

Tabela 19. Apresentação tabular dos dados para o cálculo do coeficiente de correlação de Pearson ( $\mathbf{r}$ ) segundo atividade mensal de $C x$. quinquefasciatus e pluviosidade no Parque Ecológico do Tietê. Guarulhos. São Paulo. 1996 a 1998.

\begin{tabular}{|c|c|c|c|c|c|c|c|}
\hline Mês & $\begin{array}{c}X w \% \\
(v . x)\end{array}$ & $\begin{array}{c}\text { pp.mm } \\
\text { (v. y) }\end{array}$ & $\begin{array}{c}\text { Desvio } \\
\text { de X (x- } \\
\text { Mx) }\end{array}$ & $\begin{array}{c}\text { Desvio } \\
\text { de Y (y- } \\
\text { My) }\end{array}$ & $X^{2}$ & $\mathrm{Y}^{2}$ & $X Y$ \\
\hline A & 0.0 & 37 & -15 & $-101,9$ & 225 & 10383,61 & 1528.5 \\
\hline $\mathrm{S}$ & 3.5 & 148 & $-11,5$ & 9,1 & 132,25 & 82,81 & -104.65 \\
\hline $\mathrm{O}$ & 11.0 & 217 & -4 & 78,1 & 16 & 6099,61 & -868.00 \\
\hline $\mathrm{N}$ & 11.0 & 217 & 22.4 & 78,1 & 16 & 2199,61 & -2244.8 \\
\hline D & 39.4 & 92 & 31,1 & $-46,9$ & 595,36 & 6577.21 & 6842 \\
\hline $\mathbf{J}$ & 46.1 & 220 & $-14,5$ & 81,1 & 210,25 & 7761,61 & -1277.45 \\
\hline$F$ & 0.5 & 227 & $-10,7$ & 88,1 & 114,49 & 16154,41 & -1359.97 \\
\hline $\mathbf{M}$ & 4.3 & 266 & $-7,9$ & 127,1 & 62,41 & 524,41 & 180.91 \\
\hline $\mathrm{A}$ & 7.1 & 116 & 4,4 & -102.9 & 19,36 & 10588,41 & -452.76 \\
\hline $\mathbf{M}$ & 19.4 & 70 & -2 & $-68,9$ & 4 & 4747,21 & 137.8 \\
\hline $\mathrm{J}$ & 13.0 & 97 & -13 & $-41,9$ & 169 & 1755,61 & 544.7 \\
\hline $\mathrm{J}$ & 2.0 & 6 & -11.9 & -132.9 & 141,61 & 17662,41 & 1581.51 \\
\hline A & 3.1 & 21 & -11.6 & $-117,9$ & 134,56 & 13900,41 & 1367.64 \\
\hline $\mathrm{S}$ & 3.4 & 102 & -4.5 & $-36,9$ & 20,25 & 1361,61 & 166.05 \\
\hline $\mathrm{O}$ & 10.5 & 106 & $-7,5$ & -32.9 & 56,25 & 1082,41 & 246.75 \\
\hline $\mathrm{N}$ & 18.2 & 126 & 3,2 & $-12,9$ & 10.24 & 166,41 & -41.28 \\
\hline $\mathrm{D}$ & 11.0 & 158 & -4 & -19.1 & 16 & 364,81 & 76.4 \\
\hline $\mathrm{J}$ & 13.3 & 208 & $-1,7$ & 69,1 & 2,89 & 4774,81 & -117.47 \\
\hline $\mathrm{F}$ & 10.8 & 319 & -4.2 & 180,1 & 17,64 & 32436,01 & -756.42 \\
\hline $\mathbf{M}$ & 75.9 & 207 & 60,9 & 68,1 & 3708,81 & 4637,61 & 4147.29 \\
\hline $\begin{array}{c}\text { Total } \\
\text { Média }\end{array}$ & $\begin{array}{c}300,0 \\
\mathrm{Mx}=15\end{array}$ & $\begin{array}{c}2779 \\
M y=138,9\end{array}$ & 0 & 1 & $\Sigma X 2=6623,58$ & $\Sigma Y 2=86088,06$ & $\Sigma(X Y)=9596,75$ \\
\hline
\end{tabular}

$\mathrm{Xw} \%=$ Média de Williams $(\mathrm{v} . \mathrm{x}=$ variável $\mathrm{x})$

ppmm. precipitação média mensal em milimetros de chuva ( $\mathrm{v}: \mathrm{y}=$ variável $\mathbf{y})$. 
Tabela 20. Apresentação tabular dos dados para o cálculo do coeficiente de correlação de Pearson ( $\mathrm{r}$ ) segundo a atividade mensal de $\boldsymbol{C} x$. quinquefasciatus e temperatura no Parque Ecológico do Tietê, Guarulhos. São Paulo. 1996 a 1998.

\begin{tabular}{|c|c|c|c|c|c|c|c|}
\hline Mès & $\begin{array}{l}X w \% \\
(v \cdot x)\end{array}$ & $\begin{array}{c}\text { Temperatura } \\
(\mathrm{v} \cdot \mathrm{y})\end{array}$ & $\begin{array}{c}\text { Desvio de } \mathrm{X} \\
(\mathrm{x}-\mathrm{Mx})\end{array}$ & $\begin{array}{c}\text { Desvio de } Y \\
(y-M y)\end{array}$ & $\mathrm{X}^{2}$ & $\mathrm{Y}^{2}$ & $\mathrm{XY}$ \\
\hline $\mathrm{A}$ & 0.0 & 17 & -15 & -3.9 & 225 & 15.21 & 58.5 \\
\hline $\mathrm{S}$ & 3.5 & 18.1 & -11.5 & -2.8 & 132.25 & 7.84 & 32.2 \\
\hline $\mathrm{O}$ & 11.0 & 19.8 & -4 & -1.1 & 16 & 1.21 & 4.4 \\
\hline $\mathrm{N}$ & 39.4 & 20.2 & 24.4 & -0.7 & 595,36 & 0,49 & $-17,08$ \\
\hline $\mathrm{D}$ & 46.1 & 22.4 & 31.1 & 1.5 & 967.21 & 2.25 & 46.65 \\
\hline $\mathrm{J}$ & 0.5 & 22.4 & -14.5 & 1.5 & 210.25 & 2.25 & -21.75 \\
\hline $\mathrm{F}$ & 4.3 & 23.0 & -10.7 & 2.1 & 114.49 & 4.41 & $-22,47$ \\
\hline $\mathrm{M}$ & 7.1 & 21.5 & -7.9 & 0.6 & 62.41 & 0.36 & -4.74 \\
\hline $\mathrm{A}$ & 19.4 & 20.2 & 4.4 & -0.7 & 19.36 & 0.49 & -3.08 \\
\hline$M$ & 13.0 & 17.9 & -2 & -3 & 4.0 & 9.0 & 6 \\
\hline $\mathrm{J}$ & 2.0 & 16.7 & -13 & -4.2 & 169 & 17.64 & 54.6 \\
\hline $\mathrm{J}$ & 3.1 & 17.8 & -11.9 & -3.1 & 141.61 & 9.61 & 36.89 \\
\hline A & 3.4 & 17.8 & -11.6 & -3.1 & 134.56 & 9.61 & 35.96 \\
\hline $\mathrm{S}$ & 10.5 & 19.5 & -4.5 & -1.4 & 20.25 & 1.96 & 6.3 \\
\hline $\mathrm{O}$ & 7.5 & 21.5 & -7.5 & 0.6 & 56.25 & 0.36 & -4.5 \\
\hline$N$ & 18.2 & 23.9 & 3.2 & 3 & 10.24 & 9.0 & 9.6 \\
\hline $\mathrm{D}$ & 11.0 & 24.9 & -4.0 & 4 & 16 & 16 & -16 \\
\hline $\mathrm{J}$ & 13.3 & 25.1 & -1.7 & 4.2 & 2.89 & 17.64 & -7.14 \\
\hline $\mathrm{F}$ & 10.8 & 24.6 & -4.2 & 3.7 & 17.64 & 13.69 & -15.54 \\
\hline $\mathrm{M}$ & 75.9 & 23.2 & 60.9 & 2.3 & 3708.81 & 5.29 & 140.07 \\
\hline $\begin{array}{c}\text { Tota } \\
1 \\
\text { Méd } \\
\text { ia }\end{array}$ & $\begin{array}{c}300 \\
M x=15\end{array}$ & $\begin{array}{c}417.5 \\
M y=20.8\end{array}$ & 0 & -0.5 & $\sum X^{2}=6623.58$ & $\Sigma Y^{2}=144.31$ & 318.87 \\
\hline
\end{tabular}

$\mathrm{X} w{ }^{0}=$ Media de Williams $(\mathrm{v} x=$ variavel $\mathrm{x})$

Temperatura média mensal ( ${ }^{\circ} \mathrm{C}$ ) (variável y) 


\section{A8}

Tabela 21. Apresentação tabular dos dados para o cálculo do coeficiente de correlação de Pearson ( $\mathbf{r}$ ) segundo atividade mensal de $C \boldsymbol{x}$ declarator e pluviosidade no Parque Ecológico do Tietê. Guarulhos, São Paulo. 1996 a 1998

\begin{tabular}{|c|c|c|c|c|c|c|c|}
\hline Mês & $\begin{array}{l}X w \% \\
(v . x)\end{array}$ & $\begin{array}{l}\text { ppmm } \\
\text { (v.y) }\end{array}$ & $\begin{array}{c}\text { Desvio } \\
\text { de X (x- } \\
\mathrm{Mx})\end{array}$ & $\begin{array}{l}\text { Desvio de } \\
X(y-M y)\end{array}$ & $\mathrm{X}^{2}$ & $\mathrm{Y}^{2}$ & $X Y$ \\
\hline $\mathrm{A}$ & 41.6 & 37 & 26.6 & -101.9 & 707.56 & 10383,61 & -2710.54 \\
\hline $\mathrm{S}$ & 10.5 & 148 & -4.5 & 9.1 & 20,25 & 82.81 & 40.95 \\
\hline $\mathrm{O}$ & 14.7 & 217 & -0.3 & 78.1 & 0.09 & 6099.61 & -23.43 \\
\hline $\mathrm{N}$ & 9.9 & 92 & -5.1 & -46.9 & 26.01 & 2199.61 & 239.19 \\
\hline $\mathrm{D}$ & 23.3 & 220 & 8.3 & 81.1 & 68,89 & 6577.21 & 673.13 \\
\hline $\mathrm{J}$ & 0.0 & 227 & -15 & 88.1 & 225 & 7761.61 & -1321.5 \\
\hline$F$ & 5.1 & 266 & -9.9 & 127.1 & 98.01 & 16154.41 & -1258.29 \\
\hline $\mathrm{M}$ & 1.1 & 116 & -13.9 & -22.9 & 193.21 & 524.41 & 318.31 \\
\hline $\mathrm{A}$ & 13.2 & 36 & -1.8 & -102.9 & 3.24 & 10588.41 & 185.22 \\
\hline $\mathrm{M}$ & 7.5 & 70 & -7.5 & -68.9 & 56.25 & 4747.21 & 516.75 \\
\hline $\mathrm{J}$ & 3.4 & 97 & -11.6 & -41.9 & 134.56 & 1755.61 & 486.04 \\
\hline $\mathrm{J}$ & 0.0 & 6 & -15 & -132.9 & 225 & 17662.41 & 1993.5 \\
\hline A & 11.0 & 21 & -4 & -117.9 & 16 & 13900.41 & 471.6 \\
\hline $\mathrm{S}$ & 21.7 & 102 & 6.7 & -36.9 & 44.89 & 1361.61 & 247.23 \\
\hline $\mathrm{O}$ & 6.1 & 106 & -8.9 & -32.9 & 79.21 & 1082.41 & 292.81 \\
\hline $\mathrm{N}$ & 2.4 & 126 & -12.6 & -12.9 & 158.76 & 166.41 & 162.54 \\
\hline $\mathrm{D}$ & 28.5 & 158 & 13.5 & -19.1 & 182,25 & 364.81 & -257.85 \\
\hline $\mathrm{J}$ & 23.6 & 208 & 8.6 & 69.1 & 73.96 & 4774.81 & 594.26 \\
\hline $\mathrm{F}$ & 10.9 & 319 & -4.1 & 180.1 & 16.81 & 32436.01 & -738.41 \\
\hline $\mathrm{M}$ & 65.5 & 207 & 50.5 & 68.1 & 2550.25 & 4637.61 & 3439.05 \\
\hline $\begin{array}{l}\text { Total } \\
\text { Média }\end{array}$ & $\begin{array}{c}300 \\
M x=15\end{array}$ & $\begin{array}{c}2779 \\
M y=138.9\end{array}$ & 0 & 1 & $\Sigma X^{2}=4880.2$ & $\Sigma Y^{2}=186088,06$ & $\Sigma(X Y)=3268,66$ \\
\hline
\end{tabular}

$\mathrm{X} \mathbf{w} \%=$ Média de Williams ( $\mathrm{x} . \mathrm{x}=$ variável $\mathrm{x}$ ).

ppmm = precipitação média mensal em milimetros de chuva $(v y=$ variável $y)$. 
Tabela 22. Apresentação tabular dos dados para o càlculo do coeficiente de correlação de Pearson ( $\mathbf{r}$ ) segundo atividade mensal de $\boldsymbol{C} x$, declarator e temperatura no Parque Ecológico do Tietê. Guarulhos. São Paulo. 1996 a 1998.

\begin{tabular}{|c|c|c|c|c|c|c|c|}
\hline Mês & $\begin{array}{l}X w \% \\
(v \cdot x)\end{array}$ & $\begin{array}{c}\text { Temperatura } \\
\text { (v.y) }\end{array}$ & $\begin{array}{c}\text { Desvio } \\
\text { de X }(\mathrm{x}- \\
\mathrm{Mx})\end{array}$ & $\begin{array}{c}\text { Desvio de } Y \\
(y-M y)\end{array}$ & $X^{2}$ & $Y^{2}$ & $X Y$ \\
\hline A & 41.6 & 17 & 26.6 & $-3,9$ & 707,56 & 15,21 & $-103,74$ \\
\hline $\mathrm{S}$ & 10.5 & 18.1 & $-4,5$ & $-2,8$ & 20,25 & 7,84 & 12.6 \\
\hline $\mathrm{O}$ & 14.7 & 19.8 & -0.3 & $-1,1$ & 0,09 & 1.21 & 0,33 \\
\hline$N$ & 9.9 & 20.2 & -5.1 & -0.7 & 26.01 & 0.49 & 3.57 \\
\hline $\mathrm{D}$ & 23.3 & 22.4 & 8.3 & 1.5 & 68,89 & 2.25 & 12.45 \\
\hline$J$ & 0.0 & 22.4 & -15 & 1.5 & 225 & 2.25 & -22.5 \\
\hline $\mathrm{F}$ & 5.1 & 23.0 & -9.9 & 2.1 & 98,01 & 4.41 & $-20,79$ \\
\hline $\mathrm{M}$ & 1,1 & 21.5 & -13.9 & 0,6 & 193,21 & 0,36 & -8.34 \\
\hline A & 13.2 & 20.2 & $-1,8$ & $-0,7$ & 3.24 & 0.49 & 1.26 \\
\hline M & 7,5 & 17.9 & -7.5 & -3 & 56.25 & 9.0 & 22.5 \\
\hline$J$ & 3.4 & 16.7 & -11.6 & -4.2 & 134,56 & 17.64 & 48,72 \\
\hline $\mathrm{J}$ & 0.0 & 17.8 & -15 & $-3,1$ & 225 & 9.61 & 46,5 \\
\hline A & 11.0 & 17.8 & -4 & -3.1 & 16 & 9.61 & 12.4 \\
\hline $\mathrm{S}$ & 21.7 & 19.5 & 6.7 & -1.4 & 44.89 & 1.96 & -9.38 \\
\hline $\mathrm{O}$ & 6.1 & 21.5 & -8.9 & 0.6 & 79.21 & 0.36 & -5.34 \\
\hline$N$ & 2.4 & 23,9 & -12.6 & 3 & 158.76 & 9 & -37.8 \\
\hline $\mathrm{D}$ & 28.5 & 24.9 & 13,5 & 4,0 & 182.25 & 16 & 54,0 \\
\hline J & 23.6 & 25.1 & 8.6 & 4.2 & 73.96 & 17,64 & 36.12 \\
\hline $\mathrm{F}$ & 10.9 & 24.6 & -4.1 & 3,7 & 16,81 & 13.69 & -15.17 \\
\hline $\mathbf{M}$ & 65.5 & 23.2 & 50.5 & 2.3 & 2550.25 & 5.29 & 116.15 \\
\hline $\begin{array}{l}\text { Total } \\
\text { Média }\end{array}$ & $\begin{array}{c}300 \\
M x=15\end{array}$ & $\begin{array}{c}+17.5 \\
M y=20.9\end{array}$ & 0 & $-0,5$ & $\Sigma \mathrm{X}^{2}=4880,2$ & $\Sigma Y^{2}=144.31$ & $\Sigma(X Y)=143,54$ \\
\hline
\end{tabular}

$\mathrm{X} w \%=-$ Média de Williams ( $\mathrm{v} \cdot \mathrm{x}=$ variável $\mathrm{x}$ )

Temperatura média mensal $\left({ }^{6} \mathrm{C}\right)(\mathrm{v} y=$ variável $\mathrm{y})$ 


\section{A9}

Tabela 8. Atividade mensal (Xw) de Aedes scapularis segundo técnica de coleta no Parque Ecológico do Tietê. Guarulhos. São Paulo. 1996 a 1998.

\begin{tabular}{|c|c|c|c|c|c|c|c|c|c|c|c|c|}
\hline \multirow[t]{2}{*}{ Ano } & \multirow[t]{2}{*}{ Mês } & \multirow{2}{*}{$\begin{array}{l}\mathrm{pp} \\
\mathrm{mm}\end{array}$} & \multirow{2}{*}{$\begin{array}{c}\mathrm{T} \\
{ }^{\circ} \mathrm{C}\end{array}$} & \multicolumn{3}{|c|}{ Aspirador } & \multicolumn{3}{|c|}{$\mathrm{CDC}$} & \multicolumn{3}{|c|}{ Shannon } \\
\hline & & & & No & $\overline{X w}$ & $\mathrm{Xw} \%$ & No & $\overline{X w}$ & Xw \% & No & $\mathrm{Xw}$ & $\mathrm{Xw} \%$ \\
\hline \multirow[t]{5}{*}{1996} & A & 37 & 17 & 1 & 0.0 & 0.0 & 10 & 0,8 & 0,9 & 20 & 9.5 & 2.9 \\
\hline & $\mathrm{S}$ & 148 & 18,1 & 2 & 0,0 & 0.0 & 0 & 0.0 & 0,0 & 0 & 0,0 & 0.0 \\
\hline & $\mathrm{O}$ & 217 & 19.8 & 201 & 32.6 & 7,8 & 260 & 42.5 & 46.3 & 108 & 53,5 & 16.5 \\
\hline & $N$ & 92 & 20.2 & 1766 & 293.5 & 70.1 & 98 & 15.5 & 17.0 & 180 & 89,5 & 27.6 \\
\hline & $\bar{D}$ & 220 & 22.4 & 561 & 92.6 & 22.1 & 202 & 32.8 & 35,8 & 344 & 171.5 & 53.0 \\
\hline \multirow[t]{12}{*}{1997} & $J$ & 227 & 22,4 & 33 & 4.6 & 1.0 & 141 & 22.6 & 3.2 & 25 & 12 & 1.7 \\
\hline & $F$ & 266 & 23.0 & 247 & 40,3 & 9.6 & 741 & 122.6 & 17.4 & 250 & 124.5 & 18.1 \\
\hline & $\mathrm{M}$ & 116 & 21.5 & 115 & 18.3 & 4.3 & 414 & 68.1 & 9.7 & 109 & 54.0 & 7.8 \\
\hline & A & 36 & 20.2 & 183 & 29.6 & 7.0 & 128 & 20,5 & 3,0 & 41 & 20,0 & 2.9 \\
\hline & $\mathbf{M}$ & 70 & 17,9 & 28 & 3.8 & 1.0 & 19 & 2.3 & 0,3 & 8 & 3.5 & 0.5 \\
\hline & J & 97 & 16.7 & 106 & 16.8 & 4,0 & 97 & 15,3 & 2,1 & 6 & 2,5 & 0.3 \\
\hline & J & 6 & 17,8 & 224 & 36.5 & 8.7 & 148 & 23.8 & 3.3 & 58 & 28.5 & 4.1 \\
\hline & A & 21 & 17,8 & 4 & 0,0 & 0.0 & 21 & 2,6 & 0,3 & 35 & 17.0 & 2.5 \\
\hline & $\mathbf{S}$ & 102 & 19.5 & 2 & 0.0 & 0,0 & 1 & 0.0 & 0.0 & 1 & 0.0 & 0.0 \\
\hline & $\mathrm{O}$ & 106 & 21,5 & 228 & 37,1 & 8.8 & 130 & 20.8 & 3,0 & 59 & 29.0 & 4.2 \\
\hline & $N$ & 126 & 23,9 & 980 & 162.5 & 38.4 & 1517 & 252 & 35.7 & 436 & 217,5 & 32.0 \\
\hline & D & 158 & 24,9 & 444 & 73,1 & 17.2 & 938 & 155.5 & 22,0 & 356 & 177.5 & 25.9 \\
\hline \multirow[t]{3}{*}{1998} & $\mathrm{~J}$ & 208 & 25,1 & 477 & 78.6 & 5.0 & 150 & 24.1 & 1,5 & 84 & 41.5 & 7.7 \\
\hline & $F$ & 319 & 24.6 & 2826 & 470.1 & 29.2 & 3642 & 606.1 & 37.9 & 591 & 295,0 & 55.3 \\
\hline & $\mathbf{M}$ & 207 & 23,2 & 6354 & 1058.1 & 65.8 & 5835 & 971.6 & 60,6 & 395 & 197.0 & 37.0 \\
\hline
\end{tabular}

$\mathbf{X w}=$ Média de Williams.

-ppmm= pluviosidade em milimetros de chuva: $\mathrm{T}{ }^{\circ} \mathrm{C}=$ temperatura média mensal (Fonte: Estação Meteorológica De Superficie Do Aeroporto De Guarulhos - INFRAERO) 
Tabela 9. Atividade mensal (Xw) de Cx quinquefasciatus segundo a pluviosidade e técnica de coleta no Parque Ecológico do Tietĉ. Guarulhos. São Paulo. 1996 a 1998.

\begin{tabular}{|c|c|c|c|c|c|c|c|c|c|c|c|c|}
\hline \multirow[t]{2}{*}{ Ano } & \multirow[t]{2}{*}{ Mês } & \multirow{2}{*}{$\begin{array}{l}\mathrm{pp} \\
\mathrm{mm}\end{array}$} & \multirow{2}{*}{$\begin{array}{l}\mathrm{T} \\
{ }^{\circ} \mathrm{C}\end{array}$} & \multicolumn{3}{|c|}{ Aspirador } & \multicolumn{3}{|c|}{$\mathrm{CDC}$} & \multicolumn{3}{|c|}{ Shannon } \\
\hline & & & & No & $\mathrm{Xw}$ & $X w \%$ & No & $X w$ & $X w \%$ & No & $X w$ & Xw \% \\
\hline \multirow[t]{5}{*}{1996} & A & 37 & 17 & 5 & 0.0 & 0.0 & 9 & 0.6 & 1.8 & 1 & 0.0 & 0.0 \\
\hline & $\mathrm{S}$ & 148 & 18.1 & 73 & 11.3 & 3.5 & 55 & 8,3 & 24.9 & 63 & 31.0 & 53.0 \\
\hline & $\mathrm{O}$ & 217 & 19.8 & 217 & 35.3 & 11.0 & 29 & 4.0 & 12.0 & 8 & 3.5 & 6.0 \\
\hline & $\mathrm{N}$ & 92 & 20.2 & 766 & 126.8 & 39.4 & 61 & 9.3 & 28.0 & 15 & 7.0 & 12,0 \\
\hline & $\mathrm{D}$ & 220 & 22.4 & 894 & 148.1 & 46.1 & 72 & 11.1 & 33.3 & 35 & 17.0 & 29.0 \\
\hline \multirow[t]{12}{*}{1997} & $\mathrm{~J}$ & 227 & 22.4 & 33 & 4.6 & 0.5 & 149 & 24.0 & 7.6 & 13 & 6.0 & 5,3 \\
\hline & $F$ & 266 & 23.0 & 247 & 40.3 & 4.3 & 67 & 10.3 & 3.3 & 18 & 8.5 & 7.6 \\
\hline & $M$ & 116 & 21.5 & 407 & 67 & 7.1 & 152 & 24.5 & 7.8 & 31 & 15.0 & 13.4 \\
\hline & $\mathrm{A}$ & 36 & 20.2 & 1100 & 182.5 & 19.4 & 237 & 38.6 & 12.3 & 49 & 24.5 & 21.9 \\
\hline & $\mathrm{M}$ & 70 & 17.9 & 738 & 122.1 & 13.0 & 738 & 122.1 & 39.0 & 23 & 11.0 & 9.9 \\
\hline & J & 97 & 16.7 & 120 & 19.1 & 2.0 & 120 & 19.1 & 6.1 & 6 & 2.5 & 2,2 \\
\hline & J & 6 & 17.8 & 182 & 29.5 & 3.1 & 182 & 29.5 & 9.4 & 0 & 0.0 & 0,0 \\
\hline & A & 21 & 17.8 & 197 & 32.0 & 3.4 & 10 & 0.8 & 0.2 & 2 & 0.5 & 0.4 \\
\hline & $\mathrm{S}$ & 102 & 19.5 & 600 & 99.1 & 10.5 & 75 & 11,6 & 3.7 & 54 & 26.5 & 23,6 \\
\hline & $\mathrm{O}$ & 106 & 21.5 & 430 & 70.8 & 7.5 & 24 & 3.1 & 1.0 & 4 & 1.5 & 1.3 \\
\hline & $\mathrm{N}$ & 126 & 23.9 & 1039 & 172.3 & 18.2 & 92 & 14,5 & 4.6 & 14 & 6.5 & 5.9 \\
\hline & $\mathrm{D}$ & 158 & 24.9 & 623 & 103 & 11.0 & 98 & 15.5 & 5.0 & 20 & 9.5 & 8.5 \\
\hline \multirow[t]{3}{*}{1998} & $\mathrm{~J}$ & 208 & 25.1 & 514 & 84.8 & 13.3 & 208 & 33.8 & 18.6 & 20 & 9.5 & 34.5 \\
\hline & $F$ & 319 & 24.6 & 418 & 68.8 & 10.8 & 93 & 14.6 & 8.1 & 6 & 2.5 & 9.1 \\
\hline & $M$ & 207 & 23.2 & 2908 & 483.8 & 75.9 & 802 & 132.8 & 73.3 & 32 & 15.5 & 56.4 \\
\hline
\end{tabular}

$\mathbf{X} \mathbf{w}=$ Media de Williams

-ppmm = pluviosidade em milimetros de chuva: $T^{\circ} \mathrm{C}=$ temperatura média mensal (Fonte: Estação Meteorológica De Superficie Do Aeroporto de Guarulhos -INFRAERO). 


\section{A11}

Tabela 10. Atividade mensal $(X w)$ de $C x$, declarator segundo a pluviosidade e técnica de coleta no

Parque Ecológico do Tietê. Guarulhos. São Paulo. 1996 a 1998

\begin{tabular}{|c|c|c|c|c|c|c|c|c|c|c|c|c|}
\hline \multirow[t]{2}{*}{ Ano } & \multirow[t]{2}{*}{ Mês } & \multirow{2}{*}{$\begin{array}{l}\mathrm{pp} \\
\mathrm{mm}\end{array}$} & \multirow{2}{*}{$\begin{array}{c}\mathrm{T} \\
{ }^{\circ} \mathrm{C}\end{array}$} & \multicolumn{3}{|c|}{ Aspirador } & \multicolumn{3}{|c|}{$\mathrm{CDC}$} & \multicolumn{3}{|c|}{ Shannon } \\
\hline & & & & No & $\mathrm{Xw}$ & $\mathrm{Xw} \%$ & No & $\mathrm{Xw}$ & $X w \%$ & No & $X w$ & Xw \% \\
\hline \multirow[t]{5}{*}{1996} & $\mathrm{~A}$ & 37 & 17.0 & 107 & 17.0 & 41.6 & 11 & 1.0 & 1,8 & 28 & 13.5 & 10.5 \\
\hline & $S$ & 148 & 18,1 & 31 & 4.3 & 10.5 & 150 & 24.1 & 42,9 & 2 & 0.5 & 0.4 \\
\hline & $\mathrm{O}$ & 217 & 19.8 & 41 & 6,0 & 14,7 & 22 & 2.8 & 5.0 & 3 & 1.0 & 0.8 \\
\hline & $\mathrm{N}$ & 92 & 20.2 & 29 & 4,0 & 9,9 & 65 & 10.0 & 17.8 & 29 & 14,0 & 10,9 \\
\hline & $\mathrm{D}$ & 220 & 22.4 & 62 & 9.5 & 23,3 & 115 & 18.3 & 32,5 & 200 & 99.5 & 77.4 \\
\hline \multirow[t]{12}{*}{1997} & $\mathrm{~J}$ & 227 & 22.4 & 4 & 0.0 & 0.0 & 9 & 0.6 & 0.7 & 105 & 52 & 16.6 \\
\hline & $F$ & 266 & 23.0 & 47 & 7.0 & 5.1 & 15 & 1.6 & 1.9 & 30 & 14.5 & 4.6 \\
\hline & 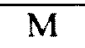 & 116 & 21.5 & 14 & 1.5 & 1.1 & 11 & 1.0 & 1.2 & 73 & 36.0 & 11.5 \\
\hline & A & 36 & 20.2 & 114 & 18.1 & 13.2 & 42 & 6.1 & 7.3 & 38 & 18.5 & 5.9 \\
\hline & $\mathrm{M}$ & 70 & 17.9 & 67 & 10.3 & 7.5 & 28 & 3.8 & 4.5 & 23 & 11.0 & 3.5 \\
\hline & $\mathrm{J}$ & 97 & 16.7 & 33 & 4,6 & 3,4 & 4 & 0.0 & 0,0 & 24 & 11.5 & 3.7 \\
\hline & $J$ & 6 & 17.8 & 0 & 0,0 & 0,0 & 0 & 0.0 & 0.0 & 0 & 0.0 & 0.0 \\
\hline & $\mathrm{A}$ & 21 & 17.8 & 95 & 15,0 & 11,0 & 8 & 0.5 & 0,6 & 12 & 5.5 & 1.7 \\
\hline & $S$ & 102 & 19.5 & 183 & 29.6 & 21.7 & 100 & 15.8 & 18,9 & 0 & 0.0 & 0.0 \\
\hline & $\mathrm{O}$ & 106 & 21,5 & 55 & 8,3 & 6.1 & 2 & 0.0 & 0,0 & 2 & 0.5 & 0.2 \\
\hline & $\mathrm{N}$ & 126 & 23.9 & 25 & 3.3 & 2,4 & 30 & 4.1 & 4,9 & 10 & 4.5 & 1.4 \\
\hline & $\mathrm{D}$ & 158 & 24.9 & 239 & 39.0 & 28.5 & 306 & 50.1 & 60,0 & 320 & 159.5 & 50.9 \\
\hline \multirow[t]{3}{*}{1998} & $\mathrm{~J}$ & 208 & 25.1 & 181 & 29.3 & 23.6 & 60 & 9.1 & 6.9 & 6 & 2.5 & 2.8 \\
\hline & $F$ & 319 & 24.6 & 86 & 13.5 & 10.9 & 13 & 1.3 & 1.0 & 23 & 11.0 & 12.5 \\
\hline & 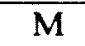 & 207 & 23.2 & 494 & 81.5 & 65,5 & 735 & 121.6 & 92.1 & 150 & 74.5 & 84.7 \\
\hline
\end{tabular}

$\mathbf{X w}=$ Média de Williams

- ppmm $=$ pluviosidade em milimetros de chuva: $\mathrm{T}^{\circ} \mathrm{C}=$ temperatura média mensal $($ Fonte = Estação

Meteorológica De Superficie Do Aeroporto De Guarulhos - INFRAERO). 